\title{
AVALIAÇÃO DA CONTAMINAÇÃO \\ POR MERCÚRIO EM PEIXES DO \\ ALTO PANTANAL
}

\author{
RÚBIA KUNO
}

Dissertação apresentada na área de concentração de Epidemiologia da Faculdade de Saúde Pública da Universidade de São Paulo para obtenção do Grau de Mestre

Área de concentração: Epidemiologia

ORIENTADORA: PROF ${ }^{\mathrm{a}}$ DRA. MARIA REGINA ALVES CARDOSO

São Paulo

2003 
Autorizo, exclusivamente para fins acadêmicos e científicos, a reprodução total ou parcial desta dissertação, por processos fotocopiadores.

Assinatura:

Data: 


\section{AGRADECIMENTOS}

À Prof ${ }^{a}$ Dra. Maria Regina Alves Cardoso pela orientação prestada e pela paciência demonstrada ao longo deste trabalho.

Ao Prof. Dr. Edinaldo de Castro e Silva do Instituto de Pesquisa Matogrossense-IPEM e UFMT, coordenador do Subprojeto 1.4- Distribuição e Transporte de Mercúrio na Bacia do Alto Paraguai, do Projeto Implementação de Práticas de Gerenciamento Integrado de Bacia Hidrográfica para o Pantanal e Bacia do Alto Paraguai ANA/GEF/PNUMA/OEA, meus sinceros agradecimentos pela disponibilização dos dados.

Ao Químico Lázaro José de Oliveira pelas valiosas sugestões e à minha amiga Elizabeth Neis pela orientação na análise estatística dos dados e pelos incentivos durante a realização deste trabalho.

Aos meus queridos filhos Thiago e Ana Maria pela paciência e compreensão. 
Ao meu pai, que sempre incentivou e apoiou a minha trajetória na busca do conhecimento 


\section{RESUMO}

Kuno, R. Avaliação da contaminação por mercúrio em peixes do Alto Pantanal-

Mato Grosso-Brasil. São Paulo, 2003. [Dissertação de Mestrado - Faculdade de Saúde Pública da Universidade de São Paulo].

Para avaliar a contaminação por mercúrio em peixes do Alto Pantanal, foram analisadas 74 amostras de peixes piscívoros das espécies Pseudoplatystoma fasciatum (cachara), Pirinanpus pirinanpu (barbado), Serrasalmus spp. (piranha), Pseudoplatystoma coruscans (pintado), Salminus maxillosus (dourado), Hemisorubin plathyrhynchos (jurupoca) e Surubin lima (jurupensém). Também foram analisadas amostras de sedimento e de material particulado em suspensão na água. As amostras foram coletadas no ano de 2000. As determinações de mercúrio total foram feitas por espectrofotometria de absorção atômica sem chama utilizando-se gerador de vapor frio VGA 77 da $\operatorname{Varian}^{\circledR}$ acoplado a um espectrofotômetro Varian ${ }^{\circledR} 220$. As concentrações de mercúrio total nas amostras de peixe variaram de $0,02 \mu \mathrm{g} / \mathrm{g}$ (piranha) a $0,80 \mu \mathrm{g} / \mathrm{g}$ (cachara). As concentrações de mercúrio em piranhas variaram de $0,02 \mu \mathrm{g} / \mathrm{g}$ a $0,50 \mu \mathrm{g} / \mathrm{g}$, com média de $0,16 \mu \mathrm{g} / \mathrm{g} \pm 0,12$. A área CBA 2 (baías do rio Cuiabá, região próxima de Barão de Melgaço) foi a que teve as concentrações mais elevadas em relação às áreas BNG 1 (rio Bento Gomes, Poconé) ( $p=0,003)$, PAG 3 (rio Paraguai, Taiamã e Descalvado) $(p=0,002)$ e PAG 5 (rio Paraguai, confluência com rio Cuiabá) ( $p<0,001)$, mas não houve diferença entre CBA 2 e PAG 4 (rio Canafisto, baía do Alegre e rio Alegre). O teste de Spearman apontou correlação entre mercúrio em piranhas e mercúrio em material particulado em suspensão $(\rho=0,561, p<0,001)$, e entre mercúrio em piranhas e mercúrio em sedimento da camada 0-2 cm; e não indicou correlações entre mercúrio em piranhas e mercúrio em sedimento da camada 0-10 cm, mercúrio em sedimento $0-10 \mathrm{~cm}$ e mercúrio em material particulado em suspensão, e mercúrio em sedimento 0-10 cm e concentração de matéria orgânica. As concentrações de mercúrio em peixes ficaram abaixo do limite máximo tolerável de mercúrio em peixes predadores, de $1 \mu \mathrm{g} / \mathrm{g}$, estabelecido no Brasil. Em regiões não contaminadas, peixes de água doce apresentam teores de $\mathrm{Hg}$ de até 0,2 $\mu \mathrm{g} / \mathrm{g}, 33 \%$ das amostras ficaram acima desse 
valor. Segundo a legislação brasileira, o pescado analisado não está impróprio para consumo humano, mas evidenciou-se um processo de contaminação que deve ser melhor estudado quanto aos fatores ambientais determinantes. É importante o monitoramento da região, já que estudos indicam que níveis abaixo de $1 \mu \mathrm{g} / \mathrm{g}$ já podem causar alterações importantes na saúde, dependendo da quantidade de pescado consumido.

Descritores: Mercúrio; contaminação em peixes; Pantanal; metais pesados. 


\section{SUMMARY}

\section{Kuno, R. Avaliação da contaminação por mercúrio em peixes do Alto}

Pantanal [Evaluation of mercury fish contamination in Alto Pantanal]. São Paulo (BR); 2003. [MS Thesis - Faculdade de Saúde Pública da Universidade de São Paulo Brazil].

In order to evaluate fish mercury contamination in Alto Pantanal region, Brazil, 74 samples of piscivorous fishes as Pseudoplatystoma fasciatum (cachara), Pirinanpus pirinanpu (barbado), Serrasalmus spp. (piranha), Pseudoplatystoma coruscans (pintado), Salminus maxillosus (dourado), Hemisorubin plathyrhynchos (jurupoca) and Surubin lima (jurupensém) were analysed in relation to total mercury. Sediment and suspended particulate matter samples were also analysed. The samples were collected in the year 2000. Total mercury concentrations were analysed by flameless atomic absorption spectrophotometry, with a spectrophotometer Varian ${ }^{\circledR} 220$ and a cold vapor generation accessory VGA 77 Varian $^{\circledR}$. Total mercury concentrations in fish ranged from $0,02 \mu \mathrm{g} / \mathrm{g}$ (piranha) to $0,80 \mu \mathrm{g} / \mathrm{g}$ (cachara). Mercury concentrations in piranha ranged from $0,02 \mu \mathrm{g} / \mathrm{g}$ to $0,50 \mu \mathrm{g} / \mathrm{g}$, with an average of $0,16 \mu \mathrm{g} / \mathrm{g} \pm 0,12$. CBA 2 area (baías from Cuiabá river, near Barão de Melgaço region) had higher concentrations than those of BNG 1 (Bento Gomes River, Poconé) ( $p=0,003)$, PAG 3 (Paraguai river, Taiamã e Descalvado) $(p=0,002)$ and PAG 5 (confluence of Cuiabá and Paraguai rivers) $(p<0,001)$, but there was no difference between CBA 2 and PAG 4 (Canafisto River, Baía do Alegre and Alegre River). Spearman Test showed correlation between values of mercury in piranha and mercury in suspended particulate matter $(\rho=0,561, p<0,001)$ and between mercury in piranha and mercury in sediment of 0-2 cm deep. However, no statistical correlations were found between mercury in piranha and mercury in sediment of 0-10 cm deep; mercury in sediment 0-10 $\mathrm{cm}$ and mercury in suspended particulate matter; and between mercury in sediment $0-10 \mathrm{~cm}$ and organic matter load. Mercury concentrations in fish were all below the Brazilian mercury limit set for predators fish that is $1 \mu \mathrm{g} / \mathrm{g}$ w.w. Freshwater fishes from non contaminated areas have total mercury load up to 0,2 $\mu \mathrm{g} / \mathrm{g}, 33 \%$ of fish samples had concentrations above this value. Despite the mercury 
concentrations were all below the Brazilian limit for a safe human consumption, a mercury contamination process is suggested. Thus, further research concerning environmental factors determining mercury contamination in Alto Pantanal region is needed. In addition, it is very important monitoring that region since previous surveys indicated that the ingestion of fish with a mercury content below $1.0 \mathrm{mg} / \mathrm{kg}$ can cause important human health effects, depending on the amount of fish consumption.

Descriptors: Mercury; fish contamination; Pantanal; heavy metals. 


\section{ÍNDICE}

1 INTRODUÇÃO

1.1 Caracterização da Área Estudada $\quad 1$

1.2 Estudo da Distribuição e Transporte de Mercúrio na Bacia do Alto 6 Paraguai do Projeto GEF Alto Paraguai

$\begin{array}{ll}1.3 \text { Justificativa } & 11\end{array}$

1.4 Histórico da Atividade Garimpeira no Estado de Mato Grosso 12

1.5 Garimpo e o Processo de Extração de Ouro 18

1.5.1 Garimpagem/Garimpo/Garimpeiro 18

1.5.2 Métodos de Lavra e Beneficiamento Utilizados nos Garimpos de 19 Ouro

1.6 Problemas Ambientais Decorrentes da Tecnologia Empregada nos 22 Garimpos de Ouro

1.7 Comportamento do Mercúrio no Ambiente e Incorporação pela Cadeia 29 Trófica Aquática

1.8 Efeitos do Mercúrio na Saúde Humana 33

1.9 Estudos Relacionados à Contaminação Ambiental por Mercúrio na 40 Região do Pantanal e Amazônia

$\begin{array}{ll}2 \text { OBJETIVOS } & 46\end{array}$

2.1 Objetivo Geral 46

2.2 Objetivos Específicos 46

3 MATERIAL E MÉTODOS 47

3.1 Região de Abrangência do Estudo, Pontos de Coleta de Amostras e 47 Período de Coleta de Amostras

3.2 Matrizes e Parâmetros Analisados $\quad 50$

3.3 Métodos Analíticos $\quad 52$

3.3.1 Determinação de Mercúrio Total e Matéria Orgânica em Sedimento 52

3.3.2 Determinação de Mercúrio Total em Material Particulado em 53 Suspensão 
3.3.3.1 Coleta e Preparação das Amostras de Peixes 53

3.3.3.2 Digestão e Leitura das Amostras de Peixes 54

3.3.3.3 Controle de Qualidade para Determinação de Mercúrio Total em 54 Peixes

3.4 Análise Estatística dos Dados $\quad 55$

4 RESULTADOS 56

4.1 Mercúrio Total nas Amostras de Peixes $\quad 56$

4.2 Mercúrio Total nas Amostras de Sedimento 62

4.3 Mercúrio Total em Material Particulado em Suspensão de Amostras de 64 Água

4.4 Correlação entre as Variáveis Estudadas 66

$\begin{array}{ll}5 \text { DISCUSSÃO } & 68\end{array}$

$\begin{array}{ll}\text { 5.1 Mercúrio em Peixes } & 68\end{array}$

$\begin{array}{ll}\text { 5.2 Mercúrio nos Sedimentos } & 76\end{array}$

5.3 Mercúrio em Material Particulado em Suspensão 79

5.4 Correlações entre Mercúrio em Peixes, Sedimentos e Material 81 Particulado em Suspensão

6 CONCLUSÕES

7 REFERÊNCIAS BIBLIOGRÁFICAS 88 


\section{LISTA DE TABELAS}

Tabela 1 Localização dos pontos de coleta de amostras por área e por coordenadas geográficas, com os respectivos tipos de amostras coletadas no estudo do projeto GEF Alto Pantanal.

Tabela 2 Localização das áreas estudadas na região do Alto Pantanal, com as respectivas matrizes coletadas e analisadas em 2000

Tabela 3 Distribuição das concentrações de mercúrio total $(\mu \mathrm{g} / \mathrm{g})$ em peixes das áreas estudadas do Alto Pantanal, segundo espécie.

Tabela 4 Concentrações de mercúrio total $(\mu \mathrm{g} / \mathrm{g})$ nas diferentes espécies de peixes analisados, segundo área de coleta.

Tabela 5 Concentrações de mercúrio total $(\mu \mathrm{g} / \mathrm{g})$ em piranhas, segundo local de coleta.

Tabela 6 Concentrações de mercúrio $(\mu \mathrm{g} / \mathrm{g})$ no sedimento do Alto Pantanal, segundo local de coleta.

Tabela 7 Concentrações de mercúrio total $(\mu \mathrm{g} / \mathrm{g})$ em amostras de material particulado em suspensão em águas das baías da bacia do Alto Paraguai, segundo local de coleta

Tabela 8 Correlações entre as variáveis mercúrio em piranha, mercúrio em sedimento 0-10 cm, mercúrio em sedimento $0-2 \mathrm{~cm}$, mercúrio em material particulado em suspensão; correlação entre mercúrio em sedimento $0-10 \mathrm{~cm}$ e em material particulado em suspensão e conteúdo de matéria orgânica.

Tabela 9 Concentrações de mercúrio em peixes na região do Alto Pantanal referentes a estudos realizados no período de 1991 a 2000, segundo espécie e local de coleta 


\section{LISTA DE FIGURAS}

Figura 1 Mapa de localização das áreas e pontos de amostragem da atividade 1.4 do Projeto GEF na Bacia do Alto Paraguai

Figura 2 Evolução da Produção Brasileira oficial de ouro de empresas mineradoras e de garimpos no período de 1966 a 2001

Figura 3 Localização das áreas estudadas com os respectivos pontos de coleta. Bacia Alto Paraguai, Mato Grosso

Figura 4 Médias das concentrações de mercúrio total $(\mu \mathrm{g} / \mathrm{g})$ em peixes, segundo espécie, e limite máximo permitido da concentração de mercúrio na musculatura de peixes predadores no Brasil de 1,0 $(\mu \mathrm{g} / \mathrm{g})($ Brasil, 1998)

Figura 5 Distribuição das médias das concentrações de mercúrio total $(\mu \mathrm{g} / \mathrm{g})$ em piranhas, segundo área de coleta

Figura 6 Concentrações de mercúrio total $(\mu \mathrm{g} / \mathrm{g})$ em material particulado em suspensão em amostras de água, segundo área de coleta. As barras verticais representam cada amostra analisada. 
LISTA DE SIGLAS A ABREVIATURAS

ANA Agência Nacional de Águas

GEF Global Environmental Facility

OEA Organização dos Estados Americanos

PNUMA Programa das Nações Unidas para o Meio Ambiente

UFMT Universidade Federal de Mato Grosso 


\section{INTRODUÇÃO}

O presente estudo consiste da avaliação da contaminação por mercúrio de uma parte do ecossistema aquático do Pantanal mato-grossense. Foram utilizados dados de concentração de mercúrio total em peixes, sedimentos, material particulado em suspensão na água, obtidos em estudo realizado no ano de 2000 pela Universidade Federal de Mato Grosso (UFMT) com apoio financeiro do GEF (Global Environment Facility). A área de estudo, Bacia do Alto Paraguai, é um ecossistema de grande importância por apresentar uma biodiversidade ímpar, o que leva à preocupação quanto à sua preservação. A partir da análise e comparação desses dados secundários com aqueles obtidos em estudos anteriores na mesma região, tentou-se avaliar a evolução da contaminação por mercúrio no ecossistema aquático da região na última década.

\subsection{Caracterização da Área Estudada}

A Bacia do Alto Paraguai (BAP) engloba duas áreas distintas em relação aos recursos naturais e condição hidrológica: o Planalto e a planície que é o Pantanal (OAS 2002).

O Pantanal, na região centro-oeste do Brasil, é uma das maiores áreas alagadas do mundo. Localiza-se no Oeste de Mato Grosso do Sul e Sudoeste de Mato Grosso. É de formação recente (Terciária e Quaternária), e constituída por terrenos Sedimentares.

Possui altitudes que variam, em média, de 100 a 200 metros. Trata-se de um prolongamento, para o norte, da Planície do Chaco (Paraguai). Essa área apresenta-se deprimida, circundada por cuestas e formações soerguidas. Os seus $137000 \mathrm{~km}^{2}$ de planície aluvial se deparam com as fronteiras da Bolívia e Paraguai, recebendo água da bacia de drenagem localizada nos níveis mais altos do seu entorno que ocupa $359.000 \mathrm{~km}^{2}$ (HAMILTON e col. 1996). A planície do Pantanal é drenada pela Bacia 
do Paraguai (Rio Paraguai, seus afluentes e sub-afluentes). A área é hidrologicamente dividida em Alto, Médio e Baixo Pantanal. Sofre inundações periódicas com as chuvas, de outubro a março, resultando em inundações anuais em mais da metade e freqüentemente mais de $90 \%$ da planície aluvial, enquanto que as áreas alagadas permanentes são mínimas (HAMILTON e col. 1996). A variação anual da área de inundação é mais extrema no Alto Pantanal, onde a inundação é máxima em março-abril e mínima em outubro-novembro (HAMILTON e col. 1996). O Alto Pantanal é a maior parte da área norte da Bacia do Rio Paraguai, incluindo o tributário Rio Cuiabá (aproximadamente $15,5-17,5^{\circ} \mathrm{S}$ e $55-59^{\circ} \mathrm{W}$ ). Suas partes mais elevadas, e que não sofrem inundações, recebem o nome de "Cordilheiras"; as partes mais baixas, sujeitas às inundações, recebem a denominação de "Baías ou Lagos".

As principais características do Pantanal são: grande mobilidade do leito fluvial e coalescência das águas durante a estação chuvosa; grande quantidade de lagoas ("baías"), algumas temporárias e outras permanentes, tendo inclusive algumas com águas salinas; pequenos cursos d'água interligados (“corixos”); pequenas elevações da planície de 2-3 metros acima do nível do plano que impedem a completa circulação da água; região com pequena inclinação no sentido leste-oeste, aproximadamente $6,0 \mathrm{~cm} / \mathrm{km}$ e de 1,5 a $3,0 \mathrm{~cm} / \mathrm{km}$ no sentido norte-sul (UFMT 1997).

Têm sido registradas grandes concentrações de chuvas durante o verão (dezembro a fevereiro) e um período de seca ocorrendo de junho a agosto. Em função da baixa declividade da região, existe normalmente um grande acúmulo de água durante a estação chuvosa, elevando o nível dos rios e lagos e até interligando-os (UFMT 1997).

A temperatura máxima na região do Pantanal acontece no mês de janeiro (normalmente entre $28^{\circ} \mathrm{C}$ e $29^{\circ} \mathrm{C}$ ), enquanto que os valores mínimos são registrados em julho, ficando em torno de $22^{\circ} \mathrm{C}$ na parte setentrional e $17^{\circ} \mathrm{C}$ na parte meridional do Pantanal (UFMT 1997). 
Os solos do Pantanal foram formados por depósitos aluviais de composição argilosa (areia e argila, e conglomerado de sedimento de argilas), sendo os tipos mais comuns de solos o planosolo e lateritos hidromórficos (UFMT 1997).

A vegetação do Pantanal é variada. As diferentes fisionomias vegetais são denominadas de "Complexo do Pantanal" e é composto de savanas, campos abertos, pântanos com vegetação hidrofílica, floresta tropical semi-decídua, dentre outros. Esta paisagem sofre influência direta de suas bordas: norte-Amazônia, nordesteSavanas e ao sul e sudeste-Floresta Atlântica (UFMT 1997).

A planície aluvial do Pantanal é verdadeiramente única no mundo em abundância de pássaros (mais de 650 espécies), peixes e jacarés. A ictiofauna compreende mais de 260 espécies. Os peixes têm grande importância sócio-econômica na Bacia do Alto Paraguai, explorados como recurso pesqueiro (MMA 1997).

A região do Pantanal não é permanentemente inundada, mesmo durante os períodos das enchentes. As áreas inundadas podem variar em extensão, níveis das camadas d'água e duração da inundação. Em função disto, a característica da maior parte do Pantanal não corresponde propriamente àquela de um pântano, pois não há uniformidade em toda sua extensão territorial (UFMT 1997).

O uso da terra no Planalto da Bacia do Alto Paraguai é voltado principalmente para agricultura (pastagem e produção de soja e arroz), que teve expansão rápida a partir da década de 1970. O entorno do Planalto, o Pantanal, foi identificado como área de significância global pelo The Nature Conservancy and World Wildlife Fund (Fundo de Conservação da Natureza e Vida Selvagem) (OAS 2002).

O Plano de Conservação da Bacia do Alto Paraguai (PCBAP) implementado pelo Ministério do Meio Ambiente, dos Recursos Hídricos e Amazônia Legal (MMA) estabeleceu como problemas ambientais prioritários tanto para a Bacia do Alto Paraguai quanto para o Pantanal, o carreamento do solo das áreas agricultáveis, a 
contaminação por poluentes orgânicos e metais pesados resultantes da agricultura e mineração, e nutrientes de esgotos de áreas urbanas (OAS 2002).

Em relação às atividades de mineração na região do Pantanal, a cidade de Poconé, localizada à borda do Pantanal a 90 km de Cuiabá, teve a partir de 1982 a exploração de ouro como principal atividade econômica superando a tradicional pecuária (VEIGA e FERNANDES 1991). Assim, Poconé tornou-se o principal pólo da exploração de ouro na região.

Em razão das emissões de mercúrio a partir de algumas drenagens de áreas de garimpo de ouro dessa região e os achados recentes de altos níveis de mercúrio natural em solos tropicais, foram realizados estudos sobre o ciclo de mercúrio no Pantanal mato-grossense.

É grande a contribuição de mercúrio de origem antropogênica na quantidade total desse metal em peixes em muitas regiões de clima temperado, principalmente naquelas que possuem florestas boreais como o Norte Europeu (HYLANDER e col. 2000a). Porém, não há estudos conclusivos sobre o assunto nos peixes de regiões tropicais. No entanto, os peixes são uma importante fonte de alimento e algumas espécies podem ser utilizadas como bioindicadores. Muitos fatores que influenciam os níveis de mercúrio em peixes nos trópicos são ainda pouco entendidos, por exemplo, as mudanças sazonais, carbono orgânico dissolvido na água e a grande quantidade de biomassa (HYLANDER e col. 2000a).

A pesca é um importante recurso para os habitantes do Pantanal, seja diretamente para consumo ou indiretamente como atrativo para o grande número de turistas que visitam a região. Um exemplo é a comunidade de Barão de Melgaço (6 000 habitantes). Ela foi fundada devido à produção de álcool e açúcar, mais tarde por causa da erosão nos campos de cana-de-açúcar e sua substituição pelas pastagens, a comunidade passou a depender da carne e couro e, atualmente, tem como principal meio de sobrevivência o comércio de pescado (MATTOS 1997). Assim, ações que 
reduzam a quantidade ou a qualidade do peixe afetariam seriamente as condições de vida da população do Pantanal.

A ictiofauna desempenha também papel de fundamental importância, enquanto componente do ecossistema do Pantanal. Os grandes estoques pesqueiros provavelmente representam um dos maiores compartimentos de reserva viva de nutrientes e de energia do sistema, com implicações óbvias na circulação e fluxo destes elementos. Os peixes, entre outras funções, atuam como dispersores de sementes e constituem a alimentação básica para muitos componentes da fauna (CATELLA 1992 citado por MMA 1997), fato que aponta para a necessidade de se avaliar a contaminação do pescado da região em relação ao seu potencial de transmissão da carga de contaminantes para os seus predadores.

Segundo levantamento feito pelo Plano de Conservação da Bacia do Alto Paraguai (MMA 1997), o maior esforço de pesca recai principalmente sobre as espécies de médio e grande portes, na Bacia do Alto Paraguai (BAP). Estas espécies são consideradas nobres, pois representam um troféu para os pescadores esportivos e alcançam os melhores preços para os pescadores profissionais. Embora ocorram mais de 260 espécies de peixes na região, apenas 10 espécies responderam por mais de $80 \%$ de todo o desembarque pesqueiro oficialmente registrado na BAP, no ano de 1995: Pseudoplatystoma corruscans (pintado), Piaractus mesopotamicus (pacu), Leporinus sp (piavuçu), Pseudoplatystoma fasciatum (cachara), Prochilodus lineatus (curimbatá), Paulicea luetkeni (jaú), Pinirampus pinirampu (barbado), Salminus maxillosus (dourado), Pygocentrus nattereri (piranha) e Brycon microlepis (piraputanga). No mesmo levantamento, observou-se que 45,6\% de toda a produção recaía sobre espécies carnívoras. Os rios Paraguai e Cuiabá juntos responderam por $67,5 \%$ de toda a produção pesqueira da BAP.

Vários estudos foram desenvolvidos investigando os teores de mercúrio nas diversas matrizes ambientais e biológicas na região do Alto Pantanal. Entretanto, não existem estudos que definem o transporte de mercúrio a partir das fontes de contaminação, em especial os garimpos de ouro às bordas do Pantanal. 


\subsection{Estudo da Distribuição e Transporte de Mercúrio na Bacia do Alto Paraguai do Projeto GEF Alto Paraguai.}

Visando conhecer os pontos de acumulação de mercúrio na Bacia do Alto Paraguai e as rotas de transporte desse metal, está sendo desenvolvido pela UFMT (Departamento de Química) um estudo dentro do sub-projeto intitulado "Implementação de Práticas de Gerenciamento Integrado de Bacia Hidrográfica para o Pantanal e a Bacia do Alto Paraguai (ANA/GEF/PNUMA/OEA)". O estudo corresponde à Atividade 1.4 - Distribuição e transporte de mercúrio na bacia do Alto Paraguai do Projeto GEF Alto Paraguai e teve início no ano de 2000.

O levantamento permitirá o conhecimento geral dos pontos de acumulação de mercúrio na Bacia do Alto Paraguai e as rotas de transporte desse metal ao longo da região estudada. Essas informações deverão servir de subsídio para o sistema de monitoramento das águas da Bacia do Alto Paraguai, para definição dos melhores locais de monitoramento e inclusive do melhor bioindicador para as condições tropicais do Pantanal. Além disso, essa quantificação permitirá subsidiar a avaliação do impacto a jusante das atividades mineradoras.

O estudo tem como objetivo geral avaliar o nível de contaminação por mercúrio e seu transporte na Bacia do Alto Paraguai, o qual deverá ser atingido por meio dos seguintes objetivos específicos:

- Determinar os teores de mercúrio total em material particulado em suspensão, sedimento de fundo, perfil de sedimento, solo, peixes, e plantas aquáticas ao longo dos rios Cuiabá, Paraguai e Bento Gomes, na Bacia do Alto Paraguai (Tabela 1);

- Determinar o teor de mercúrio total em amostras de ar atmosférico nas áreasalvo (Tabela 1);

- Elaborar mapa de concentração de mercúrio nas diferentes matrizes em toda a região estudada;

- Realizar ensaios de especiação de mercúrio nas amostras de solo, material particulado em suspensão e sedimentos; e 
- Correlacionar os teores de mercúrio das amostras com outros metais/substâncias e com as variáveis físico-químicas da água da região estudada.

Os estudos e levantamentos estão sendo desenvolvidos nos rios e bacias Cuiabá, Paraguai e Bento Gomes (MT) (Figura 1). 
Tabela 1 - Localização dos pontos de coleta de amostras por área e por coordenadas geográficas, com os respectivos tipos de amostras coletadas no estudo do projeto GEF Alto Pantanal.

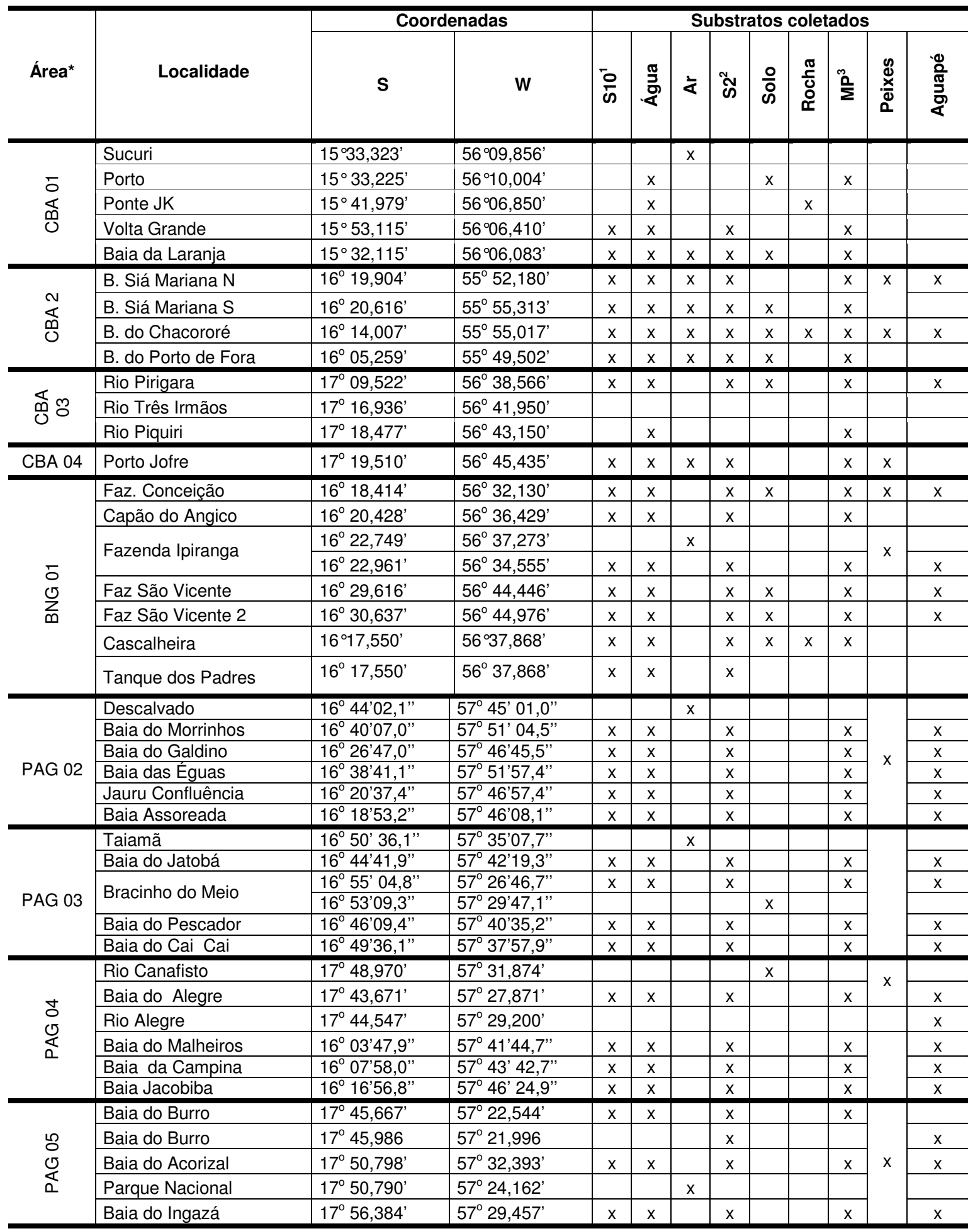

*CBA - Rio Cuiabá; BNG - Rio Bento Gomes; PAG - Rio Paraguai

${ }^{1}$ Sedimento da camada de $0-10 \mathrm{~cm}$

${ }^{2}$ Sedimento da camada de $0-2 \mathrm{~cm}$

${ }^{3}$ Material particulado em suspensão (água) 


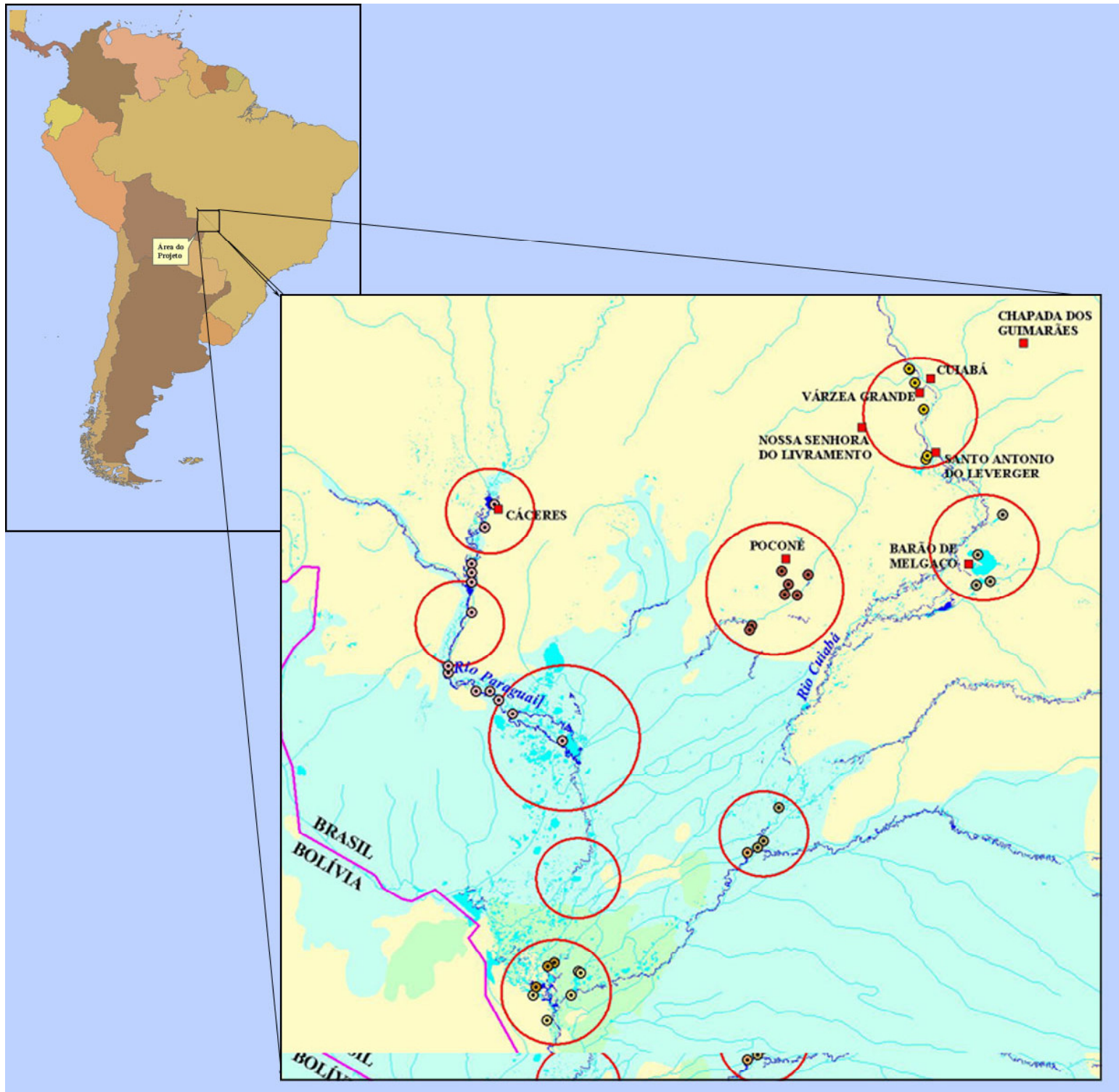

Figura 1 - Mapa de localização das áreas e pontos de amostragem da atividade 1.4 do Projeto GEF na Bacia do Alto Paraguai. 
Na primeira etapa de execução do projeto, realizada no ano de 2000 (04/8/2000 a 15/10/2000), foram definidos e amostrados 32 pontos de coleta nas baías ao longo dos rios Cuiabá e Paraguai, nos quais foram obtidas amostras de sedimento, água, material particulado em suspensão, ar, solo e peixes. Parte dessas amostras foi analisada de imediato com os recursos disponíveis na época (reagentes e equipamentos), enquanto que o restante foi devidamente acondicionado e analisado em 2002, com a reativação do projeto e a instalação de equipamentos (espectrofotômetro de absorção atômica). Todas as análises foram realizadas nas dependências do laboratório de análise de metais pesados do Departamento de Química da Universidade Federal do Mato Grosso. 


\subsection{Justificativa}

No presente trabalho, utilizando-se as informações referentes à primeira fase do estudo "Distribuição e transporte de mercúrio na bacia do Alto Paraguai" do Projeto GEF Alto Paraguai, pretendeu-se analisar os dados relacionados à contaminação por mercúrio em peixes, material particulado em suspensão e sedimentos, com o objetivo de realizar uma avaliação da evolução do processo de contaminação por mercúrio no ecossistema aquático a partir da comparação dos dados atuais com os obtidos em estudos anteriores.

Essa avaliação é justificada pela necessidade de reunir e sistematizar as informações geradas pelos vários estudos realizados na região do Pantanal, a partir do final da década de 80, para avaliar a contaminação ambiental por mercúrio a partir dos garimpos. Muitos desses estudos incluíram determinação de concentrações de mercúrio em peixes. Porém, devido a diferenças temporais e espaciais na execução desses, bem como à desarticulação desses trabalhos no sentido de se fazer uma avaliação global, menos pontual, não se tem um diagnóstico da evolução temporal da contaminação por mercúrio a partir das fontes de contaminação (garimpos).

Os garimpos localizados às bordas do Pantanal Mato-Grossense são os pertencentes à Baixada Cuiabana, região que engloba os municípios de Cuiabá, Várzea Grande, Santo Antônio do Leverger, Nossa Senhora do Livramento e parte de Poconé.

Para melhor entendimento do processo de exploração de ouro no estado de Mato Grosso, com ênfase na região da Baixada Cuiabana, bem como a caracterização deste como atividade altamente impactante sob o ponto de vista ambiental, são abordados a seguir a história da atividade garimpeira no estado e a tecnologia empregada no processo de lavra e beneficiamento do minério. 


\subsection{Histórico da Atividade Garimpeira no Estado de Mato Grosso}

Remontando ao final do século XV, observa-se que a Era dos Descobrimentos foi, em boa parte, impulsionada pelo sonho com bens minerais valiosos, ansiosamente buscados pelos europeus nas terras ainda incógnitas das Américas (MIRANDA e col. 1997). Tal objetivo foi atingido rapidamente pelas expedições espanholas, uma vez que os povos por elas conquistados já exibiam alguma familiaridade com os metais preciosos existentes em seus territórios, diferindo dos povos indígenas do Brasil, onde a descoberta de minerais valiosos ocorreu dois séculos depois da chegada dos portugueses, sendo possibilitada pela superação das dificuldades de penetração em direção ao interior, causadas principalmente pela barreira natural da Serra do Mar e pelas diversas endemias regionais.

Contrastando com os hábitos dos silvícolas da América espanhola, nossos índios não se adornavam com esses bens, além do que desconheciam ocorrências desses minerais em seus domínios.

A descoberta de ouro e diamante em Minas Gerais, nos primórdios do século XVIII, provocou uma enorme corrida à região, carreando cerca de 600000 homens da Metrópole nos primeiros sessenta anos do século (SALOMÃO 1984) e provocou, no dizer de Caio Prado Jr. (1971)..."um rush de proporções gigantescas que, relativamente às condições da Colônia, é ainda mais acentuado e violento que o famoso rush californiano do século XIX."

O contingente de pessoas que seguiu para as Gerais não era constituído apenas de gente da Metrópole e de seus escravos. Compunham-no também desertores de Santos e Rio de Janeiro e toda uma gama de vadios-mestiços, negros forros e fugidos. Deslocava-se o pólo econômico da Colônia, antes fixado na produção açucareira do Nordeste, para as riquezas minerais que se acumulavam nas serranias do interior do país (SALOMÃO 1984). 
Com a referida descoberta de ouro e diamante, desencadeou-se no século XVIII a rápida interiorização das forças produtivas na Colônia, sustentadas pelo regime escravagista e submetidas a um aparato legal essencialmente fiscalista. "Os meios de controle da produção, prontamente adotados pela Coroa absolutista, incluíam a urbanização dos sítios produtores e a instituição de normas rígidas e detalhadas que iriam distinguir a mineração autorizada da lavra clandestina, passível de severas punições" (MIRANDA e col. 1997).

Uma vez distribuídas as datas entre os senhores de escravos considerados "aptos a sustentar produções regulares e a arcar com a tributação, restava aos homens livres sem posses embrenharem-se pelos lugares ermos e aí praticarem suas lavras à distância das autoridades coloniais". "Tais homens subiam às grimpas (recôndito das serras), derivando daí a denominação de garimpeiros, e em sua faina, realizavam novas descobertas" (MIRANDA e col. 1997).

Em termos de origem mais precisa do vocábulo, pode-se remontar à data de 26 de março de 1731, dia da assinatura do Decreto Real de expropriação das minas de ouro e diamantes do Arraial do Tijuco. O termo garimpeiro correspondia então ao "nome com que se apelida neste país aos que mineram furtivamente as terras diamantinas e que assim são chamados por viverem escondidos pelas grimpas das serras" (SALOMÃO 1984).

"Mesmo após os tempos de grande atividade, a garimpagem continuou, embora discretamente, já que o acesso às lavras continuava restrito aos que dispusessem de capital e não apenas de sua força de trabalho. Tal marginalidade tornou-se mais pronunciada a partir do momento em que os empreendimentos mineiros lançaram mão de técnicas e equipamentos que revertiam em escalas maiores de produção, ao passo que os garimpeiros, até recentemente, permaneceriam restritos a atividades manuais" (MIRANDA e col. 1997).

As regiões da Grande Cuiabá, Poconé e Nova Xavantina constituíram um subcapítulo da extração mineral do século XVIII. A penetração a oeste do rio Paraná foi 
exclusiva iniciativa de paulistas que, destituídos de suas conquistas nas Gerais, após o incidente dos emboabas, se direcionaram para os sertões de Mato Grosso e Goiás, objetivando principalmente o apresamento indígena. As lavras de Cuiabá foram as mais promissoras e, através delas, se irradiou para outros locais a febre da procura do ouro. Goiás e a região de Nova Xavantina (MT) tornaram-se o terceiro eldorado do Brasil, repetindo o que ocorreu nas lavras de Minas Gerais e Mato Grosso, ou seja, o mesmo efêmero ciclo de apogeu e decadência (SEMA 1987).

A partir do final da década de 70 e nos anos 80, registrou-se um aumento vertiginoso na atividade garimpeira em nosso país, principalmente em busca de ouro na Amazônia Legal (Figura 2).

Segundo MIRANDA e col.(1997), como causa desse aumento, são considerados os seguintes fatos: desemprego crescente nas grandes cidades, forçando a inversão do fluxo migratório; a situação de seca no Nordeste; a existência de áreas com substâncias minerais de alto valor unitário e teores elevados, possibilitando a lavra rudimentar; a atratividade do preço do ouro no mercado nacional, e a dimensão que assumiu Serra Pelada, com ampla divulgação na imprensa.

Além dessas causas, pode-se também citar o fato de, historicamente, em tempos de crise econômica, a produção de ouro ter sido alternativa mais buscada, quer pelos governos, quer pelos investidores (MIRANDA e col. 1997), advindo daí o incentivo governamental ao garimpo e ao investimento na mineração do ouro.

$\mathrm{O}$ aumento da atividade garimpeira fez com que alguns problemas inerentes à mesma, que antes tinham pouca importância no cenário nacional, aumentassem em número, tamanho e importância, além de surgirem outros no bojo da intensidade elevada da atividade, levando a conflitos e crises (MIRANDA e col. 1997).

A partir da década de 90, a produção garimpeira vem diminuindo gradativamente, conforme dados oficiais, na qual a produção de 1990 registrou 71 t, variando para 7,2 t em 2001 (Figura 2). O decaimento dessa produção é creditado às dificuldades 
na manutenção da atividade garimpeira, referentes aos custos elevados dos combustíveis e peças de reposição dos equipamentos utilizados na lavra, e à exaustão dos depósitos ricos de natureza alúvio-coluvionar. O depósito primário de ouro necessita de técnicas de engenharia para ser atingido em profundidade maior, requerendo custos adicionais aos já existentes na lavra de aluvião. Além dos fatores citados que concorreram para a queda de produção do ouro, pode-se citar o preço internacional abaixo de US\$ 400,00/onça troy em meados da década de 90, valor com o qual a produção garimpeira não tem como se sustentar (MIRANDA e col. 1997).

Os primeiros garimpeiros que chegaram no norte do Estado de Mato Grosso, no ano de 1978, vieram dos garimpos da província aurífera do rio Tapajós. Utilizando métodos e equipamentos rústicos associados à coragem e espírito desbravador, os garimpeiros subiram o rio Teles Pires e seus afluentes, descobrindo importantes jazidas ao longo destes rios (SEMA 1987).

É justamente neste período, anos 70, que se reinicia no Brasil o processo de geração de patrimônio mineral pelo garimpeiro. SALOMÃO (1984) em "O Ofício e a Condição de Garimpar”, afirma: "desde o ciclo do ouro, que as descobertas minerais feitas pelos garimpeiros não apresentavam grande expressão e nestes últimos 20 anos multiplicaram-se as descobertas importantes, especialmente de ouro, cassiterita, tantalita, wolfremita e outros minerais, associados a depósitos aflorantes ou subaflorantes". 


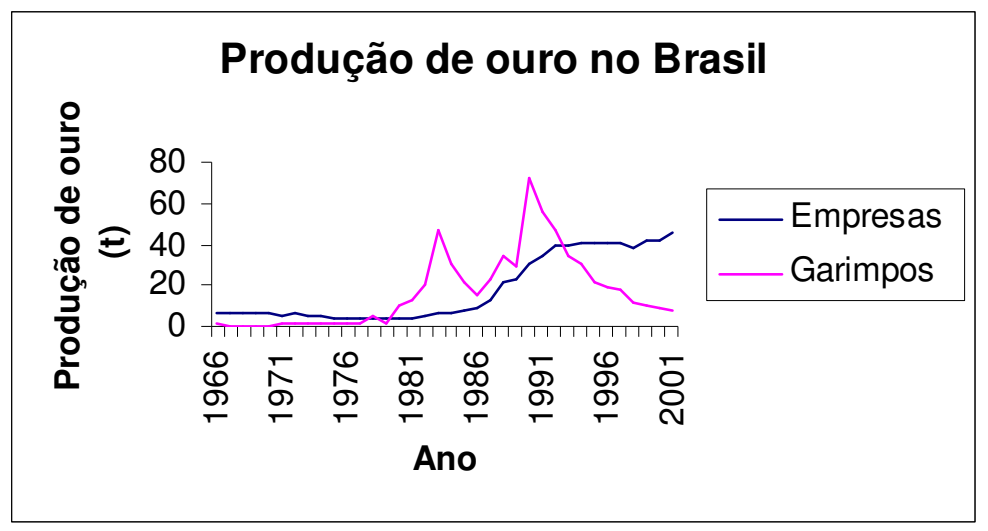

Figura 2 - Evolução da Produção Brasileira oficial de ouro de empresas mineradoras e de garimpos no período de 1966 a 2001. Fonte: MIRANDA e col. 1997; DNPM 1999, 2002.

Efetivamente, entre 1978 e 1979, ocorreu um grande marco na história da produção aurífera do país, com a introdução de maquinaria pesada na garimpagem. A partir daí também começou a ganhar peso, de forma exponencial, a variável ambiental na problemática garimpeira, ao lado do problema legal. Até 1978 esta atividade era artesanal, envolvendo o trabalho solitário de alguns homens que, com métodos rústicos produziam apenas para a sua sobrevivência (SEMA 1987).

Com a introdução de maquinaria pesada no garimpo a partir da década de 70 , a atividade passou a demandar um nível de investimento incomparavelmente superior ao que vinha ocorrendo até então. A garimpagem foi ficando assim cada vez mais seletiva, na medida que o "empresário" precisava dispor de um capital acumulado em uma outra atividade para transferi-lo ao garimpo. $\mathrm{O}$ aumento da cotação média da onça troy de ouro no mercado de Londres, nessa época, foi o que provocou toda essa transferência de recursos para o garimpo, pois a produção de ouro tornou-se mais atrativa do que muitas atividades tradicionais (SEMA 1987).

Este aumento exacerbado da cotação da onça troy, cujo preço médio no mercado internacional saltou de US\$ 39 em 1968 para US\$ 612 em 1980, possibilitou a introdução de técnicas mais sofisticadas de exploração e beneficiamento do minério aurífero, gerando verdadeiros empresários garimpeiros. A falta de perspectiva da 
esmagadora maioria da população brasileira na época, vitimada pelo desemprego e convivendo com uma inflação galopante, também acelerou o processo de “inchamento" da atividade garimpeira (SEMA 1987).

O aumento da atividade garimpeira começa a gerar conflitos devidos ao envolvimento dos garimpeiros em questões relacionadas ao cenário em que se localizam suas atividades. Dentre esses estão os conflitos entre os garimpeiros e empresas de mineração, reservas indígenas, fronteiras internacionais, tecnologia de lavra e beneficiamento, relações de trabalho, comercialização da produção, poluição e degradação ambiental (MIRANDA e col. 1997). 


\subsection{Garimpo e o Processo de Extração de Ouro}

\subsubsection{Garimpagem/Garimpo/Garimpeiro}

De acordo com o inciso I do Art. 70 (revogado) do Decreto - Lei 227 de 28/02/67 (Código de Mineração), considerava-se garimpagem “o trabalho individual de quem utilize instrumentos rudimentares, aparelhos manuais ou máquinas simples e portáteis, na extração de pedras preciosas, semi-preciosas e minerais metálicos ou não-metálicos, valiosos, em depósitos de eluvião, nos álveos de cursos d'água ou nas margens reservadas, bem como nos depósitos secundários ou chapadas (grupiaras), vertentes e altos de morros, depósitos esses genericamente denominados garimpos".

A garimpagem foi definida mais tarde no artigo $10^{\circ}$ da Lei $n^{\circ} 7805$ de 18/6/89 como sendo "a atividade de aproveitamento de substâncias minerais garimpáveis, executadas no interior de áreas estabelecidas para este fim, exercida por brasileiro, cooperativa de garimpeiros, autorizada a funcionar como empresa de mineração, sob o regime de permissão de lavra garimpeira".

Os minerais considerados garimpáveis, segundo o parágrafo primeiro do artigo supracitado são “o ouro, o diamante, a cassiterita, a columbita, a tantalita e wolframita, nas formas aluvionar, eluvional e coluvial; a scheelita, as demais gemas, o rutilo, o quartzo, o berilo, a muscovita, o espodumênio, a lepidolita, o feldspato, a mica e outros, em tipos de ocorrência que vierem a ser indicados, a critério do Departamento Nacional de Produção Mineral - DNPM".

Por fim, o parágrafo segundo do mesmo artigo enuncia que "o local em que ocorre a extração de minerais garimpáveis, na forma deste artigo, será genericamente denominado garimpo" (MIRANDA e col. 1997). 


\subsubsection{Métodos de Lavra e Beneficiamento Utilizados nos Garimpos de Ouro}

Neste item são descritos os métodos de lavra e beneficiamento, segundo MIRANDA e col. 1997.

A) Garimpagem manual: garimpagem tradicional de barrancos e catas, apoiada por equipamentos rudimentares.

Normalmente trabalha-se em equipes, em áreas de 25 até $100 \mathrm{~m}^{2}$. O "barranco" pode estar localizado em encostas de morros, em planícies de inundação dos cursos d'água (baixões) ou dentro dos leitos dos rios.

A remoção do estéril ou abertura é feita com picaretas, enxadecos e pás, acumulando-se o material para lavagem posterior. Eventualmente, o barranco localizado nas encostas de morros é secado com o auxílio de moto-bombas.

A lavagem do cascalho inicia-se por peneiramento, descartando-se o material acima de meia polegada. A fração abaixo de meia polegada é lavada em "cobra fumando", "lontona" ou "dalla", que são planos inclinados revestidos com carpetes ou sacos de juta, providos de taliscas para ajudar na retenção do ouro e na diminuição da velocidade de escoamento.

O ouro retido na "cobra fumando" é concentrado através de um processo chamado "despescagem", que consiste na amalgamação com mercúrio e concentração em bateia. Finalmente, promove-se a "queima", quando é separado o ouro do mercúrio por aquecimento, feito normalmente com maçarico ou fogão de lenha.

B) Garimpagem de balsa: garimpagem feita com equipamento de operação semimecanizado, onde a extração do cascalho do fundo dos rios é feita com "chupadeiras" controladas por mergulhadores. 
A sucção das "chupadeiras" (denominação vulgar de draga de sucção, conduzida manualmente no fundo do rio para retirar cascalho mineralizado) é realizada por bombas acionadas por motores diesel de até $32 \mathrm{hp}$. O cascalho coletado passa pelo mesmo processo de lavagem e extração descrito na garimpagem manual, porém, essa operação geralmente é realizada dentro da própria balsa.

O processo tem duração de 10 a 15 horas, utilizando-se três ou quatro trabalhadores na operação de uma balsa, sendo: um mergulhador, um outro responsável pelo contato com o mergulhador e pelo fornecimento do ar, e um ou dois para esvaziar o material grosso retido na peneira.

Visando melhorar o rendimento de recuperação, o mercúrio é freqüentemente adicionado já no plano inclinado para que se inicie ali a amalgamação.

C) Garimpagem de draga: garimpagem realizada com equipamento de operação mecânica. O cascalho do leito do rio é retirado por "chupadeiras" controladas por guinchos mecânicos, dispensando a figura do mergulhador.

A sucção utiliza bombas acionadas por motores de até $140 \mathrm{hp}$. Após a extração do cascalho, o método de processamento é semelhante àquele usado na garimpagem de balsa.

As vantagens apontadas neste processo, em relação à garimpagem de balsa, são as seguintes:

- capacidade de trabalhar em maior profundidade;

- capacidade de remover uma cobertura estéril mais espessa;

- maior duração do período de garimpagem anual;

- melhores condições de segurança de trabalho;

- menor custo de manutenção, podendo-se contar com uma equipe menor;

- os custos reduzidos permitem lavrar teores menores; 
- melhor aproveitamento do cascalho pelo acoplamento de pequenos britadores, e emprego de guinchos mecânicos para a movimentação da tubulação.

D) Garimpagem mista: utiliza o desmonte hidráulico do estéril por jatos d'água, bombeados através de mangueiras de 2 a 3 polegadas, providas de bicos para aumentar a pressão. Normalmente, o processo permite a remoção de 70 a $90 \mathrm{~m}^{3}$ de estéril/dia.

O cascalho pode ser triturado em pilões improvisados ou em britadores, e a concentração é feita em “cobra fumando", seguida de despescagem e queima.

Mais recentemente, tem-se utilizado retroescavadeira e trator de esteira para a remoção da camada estéril e caminhões para transporte do material retirado.

E) Garimpagem de ouro primário: em ocorrências de mineralizações primárias, à forma de veios em quartzo, o material, após o desmonte feito com explosivo, é reduzido usando-se britadores de mandíbula e moinho de martelo. A recuperação é feita pelos mesmos processos utilizados na garimpagem manual. Utilizam-se rotineiramente os mesmos equipamentos citados na garimpagem mista. 


\subsection{Problemas Ambientais Decorrentes da Tecnologia Empregada nos Garimpos de Ouro}

Na relação entre garimpo e meio ambiente é certo que o garimpo, como qualquer empreendimento mineral, constitui-se em atividade expressivamente transformadora do meio em que atua, podendo tornar-se fonte de poluição e degradação ambientais. Essa poluição e degradação ocorrem devido à produção rudimentar e desordenada desse tipo de atividade, cujos efeitos vêm sendo mais sentidos nas regiões dos garimpos da Amazônia Legal (MIRANDA e col. 1997).

Os prejuízos estendem-se por todos os segmentos do meio ambiente: solo, água, ar, flora e fauna.

O tema tem sido alvo de preocupação de órgãos governamentais, tendo-se desenvolvidos vários projetos na área, tais como: Programa de Monitoramento Ambiental das Áreas Garimpadas na Amazônia Legal (Departamento Nacional de Produção Mineral - DNPM), Programa Desenvolvimento de Tecnologia Ambiental (Centro de Tecnologia Mineral - CETEM) e Programa de Controle Ambiental no Rio Tapajós (Governo do Pará) (MIRANDA e col. 1997).

Esses programas, embora com dados coletados em regiões limitadas e por tempo determinado, possibilitam uma visão abrangente da realidade das regiões garimpeiras.

A erosão do solo ocorre nos baixões, onde a cobertura do solo, com altura de até 20 metros, é decapeada para se atingir o cascalho mineralizado. Onde o decapeamento não se mostra vantajoso (caso de alguns garimpos de gemas), são feitos poços e túneis que, após a extração do material desejado, são abandonados e não aterrados (MIRANDA e col. 1997).

Em locais com morros (caso de Serra Pelada), os mesmos são totalmente divididos em barrancos e desmontados até o nível do terreno, iniciando a partir dali uma cava. 
Obviamente, o nível de destruição do solo em sítios de garimpagem é relativamente baixo, porém concorre com a erosão e a contaminação por mercúrio que atinge o solo e cursos d'água. Esse processo tem início no seu manuseio inadequado e, principalmente, durante a queima do amálgama para se apurar o ouro, prática corriqueira nos garimpos brasileiros. Durante a queima, a inalação de vapor de mercúrio pode provocar sérios danos ao organismo, atingindo principalmente órgãos do aparelho circulatório e sistema nervoso e, em casos graves, culminar com a morte.

Com relação à contaminação do solo causada pela precipitação do mercúrio, tal fato pode ser verificado em cidades onde existem lojas compradoras de ouro, isso porque o metal vendido nesses locais possui aproximadamente 5\% de mercúrio, precisando ser queimado novamente para atingir teores comercializáveis (VEIGA e FERNANDES 1991).

Em Alta Floresta (MT), o CETEM realizou coletas de amostras de solo (das ruas), que acusaram até 4,10 ppm de $\mathrm{Hg}$ e teor médio de 0,23 ppm, quando a ocorrência natural desse metal em solos é de 0,10 ppm (FARID 1992).

Uma idéia da dimensão desse problema pode ser fornecida pela estimativa feita pelos pesquisadores do CETEM. Com base na quantidade de ouro comercializada na cidade em 12 anos, foram liberadas aproximadamente 7 toneladas de mercúrio através da queima nas casas compradoras.

No meio hídrico, a poluição e degradação são mais intensas. O uso de balsas e dragas nos leitos dos rios desloca grande quantidade de sedimento natural, argila e cascalho que, após a rápida passagem pelos planos e calhas inclinadas, são devolvidos aos leitos. Além de destruir o plâncton e o habitat natural de inúmeros organismos vivos, há o aumento dos sólidos em suspensão e, por conseqüência, da turbidez dos rios, além do assoreamento da drenagem. Além desses danos, é freqüente o derramamento de óleo combustível e graxas utilizados nos equipamentos (MIRANDA e col. 1997). Nos garimpos de baixão, o rejeito do beneficiamento, lançado no terreno logo à saída da calha, segue por gravidade a topografia do terreno e atinge as drenagens próximas 
dos locais de trabalho, causando o mesmo tipo de dano acima citado (FARID 1992). Esse rejeito nas drenagens leva à turbidez das águas que se estende por centenas de quilômetros, e junto com o mercúrio forma o conjunto de problemas de maior seriedade.

O comportamento biogeoquímico do mercúrio presente na água, solo e sedimentos foi intensivamente estudado em Poconé (MT) por VEIGA e FERNANDES (1991). O mercúrio metálico, por apresentar alta densidade $(13,6)$, vai imediatamente para o fundo dos rios, porém uma parte fica retida na fração fina dos sedimentos e é transportada pelas águas.

Em alguns garimpos, foi constatada a utilização do cianeto para lixiviação do ouro, substância também de grande importância toxicológica (SEMA 1987; MIRANDA e col. 1997).

Quanto à flora e fauna, realizou-se uma ampla abordagem das conseqüências da atividade garimpeira na reserva do Tapajós (MIRANDA e col. 1997), onde se analisaram as espécies que estão sujeitas à extinção devido à destruição de seu habitat por esse tipo de atividade. Estudos dos efeitos da poluição com mercúrio na cadeia alimentar e biológica foram apresentados nos trabalhos do programa Desenvolvimento de Tecnologia Ambiental, do CETEM (MIRANDA e col. 1997).

A partir de 1981, quando quase a totalidade dos garimpos, principalmente os de depósitos aluvionares no norte do estado, encontravam-se mecanizados (SALOMÃO 1984), os problemas ambientais evoluíram de maneira alarmante. Geralmente, quanto maior o grau de sofisticação nos métodos de exploração, maiores serão os impactos provenientes da atividade garimpeira sobre o meio ambiente. Estes problemas começaram a aumentar sobremaneira com o maior volume de material lavrado, em função de uma produção maior, conseqüentemente a utilização de mercúrio no processo de apuração também aumentou assustadoramente. Em anos anteriores à mecanização dos garimpos, sua atividade estava limitada a determinados tipos de depósitos. Normalmente, o processo de garimpagem era desenvolvido 
somente sobre o leito de pequenas drenagens, córregos e igarapés de terra firme de quarta e quinta ordens, e assim subseqüentemente. Estes depósitos típicos de aluviões eram lavrados manualmente durante anos, décadas, para que toda uma jazida fosse exaurida ou abandonada (SEMA 1987).

O processo normal de garimpagem manual era restrito a pequenas regiões e, conseqüentemente, os impactos por ele gerados eram muito menores. A prática usual visava exclusivamente a parte mais rica da jazida, ficando restrita basicamente à fração mais grosseira do minério contido, na sua maior parte, no leito dessas pequenas drenagens. Assim, esta prática imprimia um menor risco de comprometimento dos recursos hídricos, uma vez que muito raramente pequenas manchas da cobertura vegetal eram retiradas, os volumes trabalhados eram menores e a utilização do mercúrio era praticamente inexistente (SEMA 1987).

Os dois parâmetros ambientais maiores, volume de material tratado e despejo de mercúrio eram, neste caso, praticamente desprezíveis. Todo o processo impactante desencadeado a partir de exploração manual destas lavras era bastante localizado, ficando restrito quase que exclusivamente às áreas de despejo de resíduos do beneficiamento. Isto se deve, em parte, à localização das áreas trabalhadas, que estavam em drenagens com vazões pouco representativas, vindo amenizar sobremaneira o transporte de sólidos finos em suspensão, carreados e/ou lixiviados destas frentes de lavras. Este fato, associado à manutenção da integridade da cobertura vegetal, mais o fator tempo gasto no trabalho destes depósitos, resultavam num comprometimento pouco expressivo (SEMA 1987).

Na década de 80, com o advento da sofisticação das técnicas garimpeiras, drenagens até então inexploradas, bem como outros tipos de depósitos, passaram a ser objeto de garimpagem. Localidades cujos depósitos minerais eram inacessíveis frente aos métodos usuais empregados na exploração manual passaram a ser alvo imediato, fugindo a qualquer controle legal, quer da legislação ambiental ou mineral. Drenagens de primeira, segunda e terceira ordens foram sendo trabalhadas em todo o 
seu leito, planície de inundação e até mesmo nos seus terraços marginais, atingindo proporções que requeriam uma sofisticação técnica cada vez maior (SEMA 1987).

No primeiro grande levantamento feito no estado de Mato Grosso pelo órgão ambiental estadual sobre o impacto ambiental causado pela atividade garimpeira (SEMA 1987), a região de Poconé foi indicada como uma das mais críticas, sendo escolhida para ser estudada detalhadamente nas etapas posteriores da pesquisa. $\mathrm{O}$ critério que a incluiu entre as três mais significativas para o estudo foi a localização estratégica do município, dada a fragilidade do ecossistema (inúmeras drenagens intermitentes com número expressivo de cabeceiras que fluem para as vazantes da província Pantaneira), com extensas áreas alagadas propícias a concentrações muito altas de mercúrio no substrato de fundo. Portanto, a sua localização estratégica às bordas do Pantanal determinou a sua inclusão no estudo, embora o volume de mercúrio utilizado na área tenha sido menor comparativamente com as outras regiões do estado. A vegetação e a fauna associadas individualizam a região Pantaneira, como um ecossistema ímpar de grande importância para a conservação mundial. Nesse mesmo estudo, foi estimado que na época eram utilizados na extração de ouro $798 \mathrm{~kg}$ de mercúrio/ano nos garimpos de Poconé e $316 \mathrm{~kg}$ de mercúrio/ano nos garimpos da Baixada Cuiabana (SEMA 1987).

A partir de 1990, a Fundação Estadual do Meio Ambiente de Mato Grosso (FEMA) instituiu, através da Resolução $n^{\circ}$ 003/90, um roteiro para elaboração do Projeto de Controle Ambiental e do Plano de Recuperação de Áreas Degradadas (PRADE), para permissão de lavra garimpeira, com base na Lei 7805 de 18/7/89 que tinha como objetivo licenciar a atividade (BELLATO 2000).

No ano de 1995, foram levantados e vistoriados pela FEMA 64 garimpos na região de Poconé; destes, 32 garimpos que já se encontravam em processo de licenciamento foram avaliados quanto ao nível dos impactos e práticas de controle ambiental, e em seguida foram classificados para fins de obtenção de licença. Destes últimos 32, apenas 9 foram considerados aptos a serem licenciados, num primeiro momento. Nesse ano, nos 32 garimpos em funcionamento havia aproximadamente 3.000 
pessoas trabalhando diretamente na produção de ouro, com uma produção média de ouro estimada em 2,0 t/ano, estabilizada neste patamar desde o início da década de 90 (BELLATO 2000).

Porém, do levantamento iniciado em 1995 pela FEMA, verificou-se, em dezembro de 1996, que foram emitidas 23 Licenças de Operação a garimpos considerados de bom nível sob o ponto de vista de controle ambiental. A partir de então, acentua-se a diminuição do número de empreendimentos em operação nessa região, chegando ao final de 1997 a um número de 10 (BELLATO 2000). Essa diminuição, no caso de Poconé, pode ser atribuída ao somatório de diversos fatores, entre eles os procedimentos exploratórios não planificados, com excessiva diluição dos teores nas frentes de lavras, a conhecida baixa eficiência dos circuitos de recuperação, em média em torno de $60 \%$, a queda dos preços do ouro e o presente aumento dos custos ambientais para se manter em atividade, o que resultou em receitas operacionais incompatíveis com as necessárias para manter os empreendimentos em operação (BELLATO 2000).

O quadro atual de franco declínio da atividade em Poconé acentua-se dentro de um cenário internacional com uma tendência acentuada de queda do preço do ouro, motivado sobretudo por políticas cambiais de desvalorização monetária e crescente disponibilização no mercado de grandes quantidades de ouro pelos bancos centrais dos países exportadores (BELLATO 2000).

Dentro dos moldes em que ocorre a atividade mineradora no Estado de Mato Grosso, a atividade em desenvolvimento na bacia do rio Bento Gomes é a que mais se aproxima de um modelo de pequena mineração, considerando-se o aspecto legal da atividade, os sistemas de produção e a natureza dos depósitos.

Atualmente, os rejeitos contaminados com mercúrio estão sendo armazenados na central de amalgamação, em sacos de plástico, tambores e em tanques de concreto, embora, em alguns empreendimentos, este material esteja sendo reprocessado na planta de beneficiamento, juntamente com o minério, e bombeado para as bacias de 
contenção, pulverizando as mesmas com prováveis partículas de mercúrio, promovendo a contaminação de uma área maior (BELLATO 2000). 


\subsection{Comportamento do Mercúrio no Ambiente e Incorporação pela Cadeia Trófica Aquática}

Na natureza, a transformação do mercúrio metálico e do mercúrio inorgânico para compostos orgânicos, mais biodisponíveis, voláteis e consequientemente mais perigosos, pode ocorrer por reações químicas e biológicas.

A metilação do mercúrio inorgânico no sedimento de lagos, rios e outros corpos d'água, como também nos oceanos, é a chave no transporte de mercúrio nas cadeias alimentares aquáticas. A metilação do mercúrio vai depender de condições ambientais tais como $\mathrm{pH}$, condutividade, oxidantes, temperatura, taxa de crescimento microbiano, e a taxa de metilação é inibida pela adição de sulfeto aos sistemas anaeróbios (WHO 1989).

Compostos organo-mercuriais têm alta afinidade por tecidos vivos, por organismos, e são incorporados à cadeia alimentar. Isto pode causar acúmulo de mercúrio no nível trófico mais alto quando o valor da ingestão é maior que o da eliminação.

O ciclo bio-geoquímico natural do mercúrio é caracterizado pela sua evaporação a partir do solo e águas superficiais, seguido pelo transporte atmosférico, deposição do mercúrio de volta ao solo e águas superficiais, e a adsorção do composto no solo ou sedimentos. O mercúrio depositado na terra e na água é em parte revolatilizado de volta para a atmosfera. Devido a esse ciclo, torna-se difícil determinar o movimento do mercúrio a partir da fonte de emissão (WHO 1990).

O mercúrio ligado ao material particulado pode ser convertido a sulfeto de mercúrio insolúvel e ser precipitado ou bioconvertido em formas mais voláteis ou solúveis que voltam para a atmosfera ou são bioacumuladas nas cadeias alimentares aquática e terrestre (EPA 1984 citado por ATSDR 1999). 
O mercúrio tem três estados de valência. A forma e estado específico em que o composto é encontrado no compartimento ambiental depende de inúmeros fatores, que incluem o potencial redox e $\mathrm{pH}$ do meio. A forma mais reduzida é a metálica ou mercúrio elementar, cujo estado é líquido à temperatura ambiente, mas é prontamente vaporizado. Cerca de $95 \%$ do mercúrio encontrado na atmosfera é mercúrio gasoso $\left(\mathrm{Hg}^{0}\right)$, forma envolvida no transporte global do elemento. $\mathrm{O}$ tempo de residência na atmosfera varia de 6 dias (ANDREN e NRIAGU 1979) a 2 anos (EPA 1984 citado por ATSDR 1999).

Aproximadamente 5\% do mercúrio atmosférico está associado a particulados, que têm um tempo de residência atmosférico mais curto, são removidos por deposição úmida e seca e apresentam distribuição específica regional ou local (NATER e GRIGAL 1992). A contribuição atmosférica é mais significativa em áreas onde outras fontes de contaminação são pouco significativas ou inexistentes (ATSDR 1999). Embora as fontes locais sejam importantes, estudos indicam que o mercúrio encontrado na água de chuva pode ser originado de fontes de até $2500 \mathrm{~km}$ de distância (GLASS e col. 1991).

No solo e águas superficiais, o mercúrio pode existir nos estados mercúrico $\left(\mathrm{Hg}^{+2}\right)$ e mercuroso $\left(\mathrm{Hg}^{+1}\right)$ em numerosos complexos iônicos de diferentes solubilidades em água. A forma predominante do mercúrio presente em águas superficiais é provavelmente o mercúrio mercúrico. $\mathrm{O}$ transporte e distribuição do mercúrio nas águas superficiais e solos é influenciada pela forma do composto. Mais de $97 \%$ do mercúrio gasoso dissolvido encontrado na água é de mercúrio elementar (VANDAL e col. 1991 citado por ATSDR 1999). As formas voláteis (exemplo: mercúrio metálico e dimetilmercúrio) são evaporadas para a atmosfera, enquanto que as formas sólidas ligadas a particulados no solo ou coluna d'água são transportadas para o sedimento (HURLEY e col. 1991). A vaporização do mercúrio a partir do solo é controlada pela temperatura, sendo a emissão a partir de solos contaminados maiores em clima mais quente, quando a redução microbiana do solo de $\mathrm{Hg}^{+2}$ para o mercúrio elementar, mais volátil, é maior (LINDBERG e col. 1991). 
O processo de ligação do mercúrio ao solo ou sedimento está relacionado ao conteúdo de matéria orgânica nessas matrizes. $\mathrm{O}$ mercúrio é fortemente adsorvido a materiais húmicos e sesquióxidos em solo com $\mathrm{pH}$ maior que 4 (BLUME e BRUMMER 1991) e à camada superficial da turfa (LODENIUS e AUTIO 1989). A adsorção do mercúrio no solo diminui com o aumento do pH e/ou concentração de íons cloreto (SCHUSTER 1991). O mercúrio é adsorvido ao solo com alto conteúdo de ferro e alumínio (AHMAD e QURESHI 1989).

A forma orgânica mais comum do mercúrio, o metilmercúrio, é solúvel, móvel, e rapidamente entra na cadeia alimentar aquática. Esta forma de mercúrio é muito mais acumulada no tecido biológico do que as formas inorgânicas do mercúrio. O metilmercúrio em águas superficiais é rapidamente acumulado por organismos aquáticos; concentrações em peixes carnívoros do topo da cadeia alimentar aquática são biomagnificadas na ordem de 10000 - 100000 vezes as concentrações encontradas em ambientes aquáticos (WHO 1990, 1991; ATSDR 1999). O potencial de bioacumulação para o metilmercúrio em peixe é influenciado pelo $\mathrm{pH}$ da água, sendo observada a maior bioacumulação em águas com pH mais baixo (WATRAS e BLOOM 1992). As concentrações de mercúrio em peixe tiveram também correlação negativa com outros fatores de qualidade da água, como a alcalinidade e oxigênio dissolvido (WREN 1992 citado por ATSDR 1999).

A biomagnificação do metilmercúrio foi demonstrada pelos níveis elevados encontrados em peixes piscívoros comparados com peixes de níveis tróficos mais baixos (ATSDR 1999). Nos estudos, o peixe parece acumular metilmercúrio tanto do alimento como da coluna d'água. Entretanto, HALL e col. (1997) mostraram que a fonte predominante de absorção de mercúrio no peixe é o alimento.

Em pH entre 4-9 e uma concentração normal de sulfeto, o mercúrio formará sulfeto mercúrico. Este composto é relativamente insolúvel em solução aquosa, e assim irá precipitar e remover os íons de mercúrio da água, reduzindo a disponibilidade de mercúrio para o peixe. Sob condições ácidas, entretanto, a atividade do íon sulfeto diminui, inibindo assim a formação de sulfeto mercúrico e favorecendo a formação 
de metilmercúrio (BJORNBERG e col. 1988). Baixo pH e concentrações altas de mercúrio no sedimento favorecem a formação de metilmercúrio, que tem maior potencial de biodisponibilidade para organismos aquáticos do que compostos inorgânicos de mercúrio. O metilmercúrio é ingerido pelos organismos aquáticos dos níveis mais baixos da cadeia trófica, que por sua vez são consumidos pelos peixes piscívoros dos níveis mais altos da cadeia (COPE e col. 1990; WIENER e col. 1990). Durante o verão, as concentrações superficiais de metilmercúrio e mercúrio elementar declinam como resultado da evaporação, embora elas se mantenham constantes nas águas mais profundas (ATSDR 1999).

A redução abiótica de mercúrio inorgânico para mercúrio metálico em sistemas aquosos pode acontecer particularmente na presença de substâncias húmicas solúveis (águas ácidas contendo ácidos húmicos e fúlvicos). Este processo de redução é favorecido pela luz, ocorre sob condições aeróbicas e anaeróbicas, e é inibido pela competição dos íons cloreto (ALLARD e ARSENIE 1991).

Essas características mostram que pequenas alterações em certos estágios do ciclo de mercúrio podem trazer aumentos significativos no valor de exposição e/ou incorporação à cadeia trófica, situação que expõe grupos da população ao risco de intoxicação crônica.

Na região Amazônica, estudos mostram claramente que a deposição de mercúrio em sedimentos e solos de áreas alagadas tem aumentado no passado recente (ROULET e col. 2000). Concentrações de mercúrio no cabelo de muitas comunidades ribeirinhas estão próximas ou acima dos limites seguros, devido à alta ingestão de peixe, podendo causar efeitos neurotóxicos leves (LEBEL e col. 1996). 


\subsection{Efeitos do Mercúrio na Saúde Humana}

Os diferentes estados do mercúrio possuem propriedades químicas intrínsecas e necessitam de avaliação toxicológica independente. De uma maneira geral, pode-se considerar três formas básicas: mercúrio metálico (elementar), compostos inorgânicos e compostos orgânicos. Na avaliação das conseqüências para a saúde pública das intoxicações por mercúrio, a diferenciação do tipo de exposição torna-se útil, compreendendo a exposição ocupacional e a exposição não ocupacional (UNGAR 1998).

Os vapores de mercúrio metálico presentes no ar são prontamente absorvidos através dos pulmões após exposição por inalação, enquanto que os compostos inorgânicos e orgânicos de mercúrio são pouco absorvidos por essa via (BERLIN e col. 1969). A absorção gastrintestinal (GI) do metilmercúrio é quase completa, enquanto que a absorção GI do mercúrio inorgânico é baixa (menor que 10\%) (ATSDR 1999). O vapor de mercúrio metálico pode ser absorvido após exposição dérmica; entretanto, a absorção dérmica do vapor é muito menor (2,6\% do total absorvido através dos pulmões) do que a absorção pela via inalatória. Os sais de mercúrio inorgânico e os compostos organomercuriais também podem ser absorvidos pela pele (ATSDR 1999).

A maior parte do mercúrio presente em alimentos, pelo menos de origem animal, e principalmente em peixes, deve estar sob a forma de metilmercúrio (WHO 1989). De acordo com BERLIN (1986), os danos causados pelo consumo a longo prazo de alimento contendo metilmercúrio são devidos à sua eficiente absorção (90\%) pelo organismo humano e à sua longa meia-vida biológica (cerca de 70 dias), com acumulação de metilmercúrio no cérebro.

Cerca de $90 \%$ do total de metilmercúrio absorvido encontra-se nas hemácias, geralmente ligado à hemoglobina; no plasma encontra-se ligado às proteínas plasmáticas. A barreira hemato-encefálica constitui um obstáculo relativo à penetração do metilmercúrio no cérebro, onde níveis máximos ocorrem após 5 a 6 
dias. No tecido cerebral, encontra-se principalmente na matéria cinzenta, podendo apresentar uma concentração 5 a 10 vezes maior que aquela verificada no sangue. Devido a esta acumulação no sistema nervoso central, o cérebro é considerado o órgão crítico na intoxicação. Em indivíduos adultos, cerca de $10 \%$ do metilmercúrio total corpóreo encontra-se no cérebro e, o restante, a maior parte encontra-se no fígado e nos rins (BERLIN 1983; HUTTON 1987; KAZANTZIS 1980; MITRA 1986; WHO 1990).

O metilmercúrio presente na circulação sangüínea incorpora-se aos fios de cabelo durante sua formação, de forma proporcional. Estima-se que sua concentração seja, aproximadamente, 250 vezes maior que a concentração simultânea sangüínea. Considerando-se que, uma vez incorporado ao cabelo, a concentração capilar de metilmercúrio permanece constante no decorrer do tempo e que um fio de cabelo cresce em média $1 \mathrm{~cm}$ por mês, a medida dos níveis de metilmercúrio em segmentos consecutivos de amostras de cabelo é o melhor meio de recapitular a história individual de exposição sendo, portanto, o melhor indicador biológico nestes casos (WHO 1990).

Dados clínicos, epidemiológicos e patológicos mostram que o metilmercúrio atravessa a placenta causando intoxicação no feto. Os casos detectados em Minamata, Japão, em 1962 foram chamados de Doença Congênita de Minamata.

A cidade de Minamata localiza-se na ilha Kyushu, a sudoeste do Japão. A costa oeste da ilha é banhada pelo mar Shiranui, onde localiza-se a baía de Minamata. No início dos anos 50, começaram a aparecer peixes mortos, mariscos apareciam abertos e em estado de decomposição e as aves caíam durante o vôo. Os gatos apresentavam excessiva salivação, convulsões e freqüentemente caíam mortos. Outros animais como cães e porcos também foram afetados (HARADA 1995).

A partir de 1953 começaram a aparecer os primeiros casos humanos de uma doença com comprometimento neurológico e características de envenenamento. Casos 
congênitos começaram a ser relatados, onde recém-nascidos, de mães aparentemente sadias, eram portadores de danos cerebrais graves.

Minamata era a única cidade industrializada da área, onde a Chisso Chemical Corporation Ltd. operava desde 1907, uma das maiores e mais modernas indústrias químicas do Japão na época. Produzia fertilizantes químicos, resinas sintéticas, plásticos e produtos químicos industriais. A fábrica utilizava uma variedade de substâncias químicas e despejava o efluente líquido diretamente na baía de Minamata. Existiam evidências de que a contaminação da vida marinha, próxima à indústria, ocorria desde 1925 (HARADA 1995).

Só em 1958 um médico do "Grupo de Pesquisa da Doença de Minamata", constituído principalmente por membros da Escola de Medicina da Universidade de Kumamoto, notou que os achados clínicos e patológicos da Doença de Minamata eram idênticos àqueles observados em funcionários, vítimas de intoxicação ocupacional por mercúrio orgânico, de uma indústria inglesa de fertilizantes químicos que utilizava metilmercúrio e ocorrida em 1940 (HARADA 1995).

Experimentos realizados com gatos, alimentados com metilmercúrio e organismos marinhos afetados, demonstraram que a doença de Minamata era induzida e causada por envenenamento pelo mercúrio orgânico. $\mathrm{O}$ mesmo contaminante foi detectado em altas concentrações no sedimento e fauna da baía de Minamata. Constatou-se que tanto o metilmercúrio quanto o mercúrio inorgânico estavam presentes nos efluentes líquidos da indústria Chisso, e, em novembro de 1959, os pesquisadores informaram às autoridades de Saúde do Japão que a doença de Minamata era causada pelo metilmercúrio proveniente do efluente líquido da Chisso (UNGAR 1998).

Apesar da gravidade do problema, foi apenas em 1968 que o governo japonês reconheceu que a Doença de Minamata era provocada pela ingestão de pescado contaminado por metilmercúrio, ano também em que a indústria Chisso suspendeu a emissão de mercúrio em seus efluentes líquidos (PHILLIPS e RAINBOW 1994). 
Até março de 1992, 2252 pacientes foram reconhecidos oficialmente como vítimas da Doença de Minamata, 1043 dos quais haviam morrido. Um total de 12127 pessoas reivindicaram ser portadoras da doença, porém não foram reconhecidas como tal e outras 1968 ainda esperavam ser submetidas à avaliação do "Examining Board for the Recognition of Minamata Disease Patients" (PHILLIPS e RAINBOW 1994).

Um segundo caso de intoxicação por mercúrio ocorreu também no Japão entre pessoas que se alimentavam de peixes em Niigata nos anos de 1964 e 1965. Foram registrados 47 casos da Doença de Minamata, com 6 óbitos. As pessoas ingeriram peixes capturados no rio Agano, contaminado pelos efluentes contendo mercúrio da indústria Showa Electric (UNGAR 1998).

Outro caso de grandes proporções de intoxicação por mercúrio aconteceu no Iraque em 1971 - 1972, quando grande quantidade de sementes de trigo e cevada destinadas ao plantio foram utilizadas para consumo humano, o que levou cerca de 400 pessoas à morte. As sementes tinham sido tratadas com fungicida à base de metilmercúrio, os grãos de trigo foram utilizados na produção de pão caseiro que foi consumido pelas comunidades rurais em todo o país (WHO 1990).

De acordo com a publicação da Organização Mundial da Saúde (WHO 1976), o feto é mais sensível ao metilmercúrio do que as mães, já que em Minamata as crianças nasceram com paralisia cerebral devido ao metilmercúrio e suas mães não apresentaram a doença ou a tiveram, porém com sintomas leves.

A transferência transplacentária de compostos de metilmercúrio em humanos é bastante conhecida e é responsável pela exposição pré-natal. Comparativamente ao nível sangüíneo materno, a placenta não concentra mercúrio; porém, sua permeabilidade desempenha um papel chave na determinação da relação entre a concentração materna do metal e a dos tecidos fetais. Os eritrócitos de recémnascidos, quando comparados aos dos adultos, apresentam mais metilmercúrio, provavelmente devido ao fato de que as células fetais contêm mais hemoglobina e 
grupos sulfidrila. A concentração de metilmercúrio nos glóbulos vermelhos do recém-nascido pode ser cerca de 20 a 30\% maior que o nível sérico materno simultâneo (UNGAR 1998).

O mercúrio é encontrado no leite materno de mulheres expostas ao metilmercúrio pela ingestão de pescado (WHO 1976). Em estudo realizado no Iraque, determinouse que há uma estreita correlação entre os níveis de mercúrio total no leite e os níveis no sangue total da mãe. O conteúdo de mercúrio no leite materno corresponderia a cerca de $5 \%$ da concentração de mercúrio no sangue. Apesar dessa baixa concentração no leite, os lactentes acumularam altas concentrações no sangue. As observações clínicas no Iraque sugeriram que as mulheres são mais sensíveis aos efeitos tóxicos do metilmercúrio durante a gestação (WHO 1990).

O metilmercúrio inibe o crescimento do cérebro do feto e a migração dos neurônios da camada formadora embriológica para o destino final na córtex cerebral. Isto foi demonstrado nos casos clínicos no Japão e Iraque. A inibição do desenvolvimento cerebral do feto causada pela exposição ao metilmercúrio resulta em mudanças de comportamento e redução nas habilidades cognitivas e motoras, encontradas nos casos clínicos. Foi demonstrado que o metilmercúrio interfere na formação microtubular, na divisão celular e na síntese da proteína neuronal; tudo isso poderia explicar os efeitos descritos acima (WHO 1990).

No estudo do Iraque, foram detectados efeitos em crianças, comumente expressos como "retardamento motor", quando o nível de mercúrio no cabelo materno havia variado de 10 a 20 mg/kg durante a gestação (WHO 1990).

Vários outros estudos estão sendo desenvolvidos em diferentes regiões do mundo, relacionando a dose-resposta com a exposição pré-natal, para quantificar e qualificar os efeitos adversos do mercúrio durante o período fetal. Eles abrangem populações dos Grandes Lagos em países nórdicos e Canadá, Ilhas Seycheles, no Oceano Índico, e Ilhas Faröe, no Atlântico Norte (GRANDJEAN e col. 1998). 
Os estudos realizados com a população de Seycheles, de elevado consumo de pescado, sugeriram que não havia efeito adverso no desenvolvimento do feto, associado à concentração de mercúrio no cabelo da mãe, até o limite de 26 ppm. Entretanto, os estudos realizados nas Ilhas Faröe sugeriram que os efeitos no desenvolvimento mental da criança poderiam ocorrer, mesmo quando as gestantes apresentassem concentrações de mercúrio no cabelo de 10 ppm ou menos (GRANDJEAN e col. 1998).

Na Amazônia Brasileira, por sua vez, estudos efetuados com crianças e adultos expostos ao metilmercúrio, devido ao consumo de peixe, demonstraram efeitos neuromotores adversos, associados a concentrações de mercúrio em cabelo menores que 50 g/g (LEBEL e col. 1995; 1998; GRANDJEAN e col. 1999).

Várias agências internacionais de saúde pública tentaram determinar o risco da ingestão de metilmecúrio para a população em geral. Em 1972, a Organização Mundial da Saúde (OMS) estabeleceu uma ingestão semanal máxima tolerável de 3,3 $\mu \mathrm{g} / \mathrm{g}(0,47 \mu \mathrm{g} / \mathrm{kg}$ por dia), baseada nos dados de contaminação de Minamata (WHO 1972). A U.S.Environmental Protection Agency (U.S.EPA), baseando-se nos dados dos estudos do Iraque, estimou que a dose para o menor efeito adverso observado (Lowest Observed Effect Level - LOAEL) de metilmercúrio seria de $3 \mu \mathrm{g} / \mathrm{kg}$. Dividindo-se ainda este valor por um fator de incerteza de 10 (para dados humanos), obteve-se uma dose sem efeito observável (No Adverse Effect Level - NOAEL) de 0,3 $\mu \mathrm{g} / \mathrm{kg}$ de metilmercúrio (U.S.EPA 1992).

Subseqüentemente, a U.S.EPA, reavaliando os dados de contaminação do Iraque, propôs uma redução da dose de referência oral (RfD) para o nível de $0,1 \mu \mathrm{g} / \mathrm{kg}$ por dia (U.S.EPA 1997). A Agência de Registro de Substâncias Tóxicas e de Doenças dos EUA (ATSDR), baseando-se nos dados do estudo de Seycheles, propôs uma ingestão de 0,3 $\mu \mathrm{g} / \mathrm{kg}$ por dia como nível de risco mínimo (DAVIDSON e col. 1998). Essas variações do limite de quantidade de metilmercúrio que pode ser tolerado no consumo advêm dos diferentes estudos nos quais são baseadas e, também, dos 
fatores de incerteza considerados por cada uma das agências que efetuaram os respectivos estudos.

Os principais efeitos na saúde humana decorrentes da exposição ao metilmercúrio são os efeitos neurotóxicos em adultos (BAKIR e col. 1973) e toxicidade para os fetos cujas mães foram expostas durante a gravidez (COX e col. 1989). A principal fonte de exposição para pessoas da população geral é o consumo de pescado e, neste caso, o cérebro é o órgão crítico. Foi também demonstrado, em populações expostas a metilmercúrio, um efeito genotóxico que resulta em aberração cromossômica.

No adulto, a ação tóxica do metilmercúrio se manifesta principalmente no sistema nervoso. As lesões são localizadas e comumente são afetadas as funções sensitiva, visual e auditiva. $\mathrm{O}$ metilmercúrio inibe a síntese protéica das células neurais, sendo este um dos primeiros efeitos bioquímicos detectáveis, mas a sequiência de eventos que resultam no dano celular não está totalmente esclarecida. O metilmercúrio pode, também, reagir com receptores do sistema nervoso, inibindo, por exemplo, a transmissão da acetilcolina nas ligações neuromusculares (WHO 1990).

Em adultos, o período de latência é longo, geralmente vários meses. Os primeiros sintomas podem ser inespecíficos, tais como parestesia, mal-estar e visão obscurecida (WHO 1990). As manifestações clínicas dos efeitos neurotóxicos podem evoluir para ataxia, neurastenia, perda de visão e audição, descontrole motor e tremores e, finalmente, coma e morte (GOYER 1996). 


\subsection{Estudos Relacionados à Contaminação Ambiental por Mercúrio na Região do Pantanal e Amazônia}

Vários estudos têm relatado concentrações de mercúrio em peixes carnívoros nos ecossistemas aquáticos da Amazônia e do Pantanal. Os níveis de mercúrio variam de 0,03 a 1,65 $\mu \mathrm{g} / \mathrm{g}$ (ppm) na bacia do rio Tapajós (SANTOS e col. 2000); de nd (não detectado) a 3,8 $\mu \mathrm{g} / \mathrm{g}$ na bacia do Madeira (BOISCHIO e HENSHEL 1996); de 0,8 a 4,2 $\mu \mathrm{g} / \mathrm{g}$ no rio Negro (MALM e col. 1994); de 0,04 a 3,6 $\mu \mathrm{g} / \mathrm{g}$ na bacia do rio Teles Pires (HACON e col. 1997); de 0,013 a 0,5 $\mu \mathrm{g} / \mathrm{g}$ no rio Cuiabá (UFMT 1997) e de $<0,001$ a $0,21 \mu \mathrm{g} / \mathrm{g}$ no rio Bento Gomes na região de Poconé (MALM e GUIMARÃES 1996).

OLIVEIRA e col. (1990) analisaram os níveis de mercúrio total em peixes e também em cabelos da população da zona ribeirinha dos municípios de Barão de Melgaço e Poconé (MT). Os resultados mostraram teores de mercúrio total mais elevados para os peixes do topo da cadeia alimentar (carnívoros), principalmente a piranha (Serrasalmus nattereri), muito apreciada pela população de Poconé. Trinta por cento das amostras de cabelos coletadas apresentaram teores de mercúrio total acima do limite de segurança estabelecido pela OMS (6 ppm).

VIEIRA (1991) analisou o teor de mercúrio total no tecido muscular em amostras de peixes capturados no rio Bento Gomes. Foram encontradas concentrações de mercúrio total de até $2,29 \mu \mathrm{g} / \mathrm{g}, 7,92 \mu \mathrm{g} / \mathrm{g}, 10,25 \mu \mathrm{g} / \mathrm{g}$ e $12,78 \mu \mathrm{g} / \mathrm{g}$ em exemplares de peixe-cachorro, traíra, piranha e cachara respectivamente. As médias dos níveis de mercúrio foram $0,52 \mu \mathrm{g} / \mathrm{g}, 1,09 \mu \mathrm{g} / \mathrm{g}, 1,25 \mu \mathrm{g} / \mathrm{g}$ e $3,29 \mu \mathrm{g} / \mathrm{g}$ respectivamente para aquelas espécies, sendo que os teores mais elevados foram para os peixes carnívoros.

HYLANDER e col. (1994) analisaram mercúrio total em músculo de peixes do Alto Pantanal. Os níveis variaram de 0,05 a $0,95 \mu \mathrm{g} / \mathrm{g}$ para pintado (média de $0,26 \mu \mathrm{g} / \mathrm{g}$ ) e, para piranha, variaram de 0,09 a $0,51 \mu \mathrm{g} / \mathrm{g}$ (média de 0,28). Os peixes foram capturados em Santo Antônio de Leverger, Barão de Melgaço, Porto Jofre, Descalvado, Porto Conceição, Rosário Oeste, Porto Cercado e Pixaim. Observou-se 
uma tendência de aumento nas concentrações de mercúrio em pintado e piranha capturados no rio Cuiabá nos locais a jusante da fonte de contaminação (garimpos localizados na Baixada Cuiabana). Não foi detectada correlação significativa entre níveis de mercúrio em pintado e os parâmetros de água, porém foi encontrada uma dependência entre concentração de mercúrio em filé e distância da fonte. Por essas razões, os autores levantaram a hipótese de que, como o rio Cuiabá recebe carga de mercúrio em Cuiabá e esta é transportada para Barão de Melgaço, este mercúrio influencia os níveis em peixes em Porto Jofre mais do que em Barão de Melgaço, isto porque sofre biometilação ao longo do rio; tornando-se biodisponível nos pontos de coleta mais a jusante, como por exemplo em Porto Jofre.

MARINS e col. (1991) encontraram teores de até $1,68 \mu \mathrm{gHg} / \mathrm{m}^{3}$ no ar ambiente próximo às lojas compradoras de ouro em Poconé, indicando que as operações de queima nos centros urbanos devem ser controladas, já que as concentrações medidas ultrapassaram o limite máximo de $1,0 \mu \mathrm{gHg} / \mathrm{m}^{3}$ ar recomendado pela OMS como limite ambiental (WHO 2000). Segundo este estudo, os operadores da queima nas lojas de compra de ouro estão expostos a teores acima de $70 \mu \mathrm{gHg} / \mathrm{m}^{3}$, valor este encontrado junto à capela e que está acima dos valores para exposição ocupacional.

SILVA e SILVA (1991) encontraram teores de mercúrio no solo acima do nível de "background" da região em áreas próximas das lojas de compra de ouro, a distâncias de até 400 metros na direção predominante dos ventos.

Sabe-se que a concentração de mercúrio no cabelo é o melhor indicador biológico de exposição humana, pelo consumo de pescado, ao metilmercúrio. Geralmente, um alto consumo propicia uma maior concentração de mercúrio nas amostras de cabelo. $\mathrm{Na}$ região da Amazônia e Pantanal foram encontradas altas concentrações de mercúrio no cabelo de adultos, principalmente no Alto Tapajós, com níveis que variaram de 18,6 a $176 \mu \mathrm{g} / \mathrm{g}$ (MALM 1994); no rio Madeira, com 19,2 $\mu \mathrm{g} / \mathrm{g}$ (BOISCHIO 1996) e em Alta Floresta, com 6,2 a $174 \mu \mathrm{g} / \mathrm{g}$ (HACON e col. 1997). Porém, essas concentrações elevadas estavam associadas com alto consumo de peixes carnívoros. As exposições naquelas regiões são crônicas e com várias fontes de contaminação . 
Atualmente, uma das mais críticas questões em saúde ambiental é a determinação do nível a partir do qual o metilmercúrio é tóxico, considerando-se pessoas com exposição crônica a baixas concentrações, devida principalmente ao consumo de peixe (MAHAFFEY 2000). Estudos com pessoas que tiveram exposição crônica ao metilmercúrio sugerem que o nível de referência de $50 \mu \mathrm{g} / \mathrm{g}$ no cabelo, adotado pela OMS, pode não ser seguro para evitar os efeitos neurotóxicos desse composto (WHO 1990). Níveis de mercúrio no cabelo abaixo de $50 \mu \mathrm{g} / \mathrm{g}$ foram associados a distúrbios neuro-comportamentais relacionados, por exemplo, ao desempenho visual (discriminação cromática, sensibilidade de contraste e campos periféricos) e a funções neuromotoras (tremor, destreza, força da pegada, seqüências de movimentos complexos, coordenação mão-olho e movimentos rápidos alternados) (LEBEL e col. 1995, 1996, 1998; DOLBEC e col. 2000).

Na região de Gurupi, no Estado do Pará, outra parte da região amazônica de importância mineral, PALHETA e TAYLOR (1995) determinaram a concentração de mercúrio total e inorgânico em amostras de água, peixes, tecidos de outros animais e sangue, cabelo e urina de população garimpeira e não garimpeira. Os valores encontrados foram considerados elevados quando comparados com outros de áreas não contaminadas. Amostras de sangue, pêlo de porco, carneiro e gado bovino criados na área com acesso ao rio contaminado tiveram valores variando de 0,1 a $1,28 \mu \mathrm{g} / \mathrm{g}$ em amostras de pêlo e 11,7 a $15,7 \mu \mathrm{g} / \mathrm{g}$ em amostras de sangue. Estes valores são aproximadamente o dobro dos encontrados em animais controle. A concentração média de mercúrio em sangue, urina e cabelo dos residentes foi de 11,4 $\mu \mathrm{g} / \mathrm{L}, 22,8 \mu \mathrm{g} / \mathrm{L}$ e $4,3 \mu \mathrm{g} / \mathrm{L}$ respectivamente, enquanto que na urina dos garimpeiros os valores encontrados chegaram a $155 \mu \mathrm{g} / \mathrm{L}$.

BARBOSA e col. (1995) estudaram a contaminação por mercúrio de garimpeiros, ribeirinhos e população indígena, além de peixes da região amazônica. Também fizeram o levantamento do hábito alimentar da população estudada e verificaram estreita correlação entre a contaminação por mercúrio nos peixes, os hábitos alimentares e o teor de mercúrio no cabelo das populações. Observaram que aqueles 
que apresentaram maior consumo de peixes apresentavam também maiores teores de mercúrio no cabelo. Observaram ainda, uma grande variabilidade na concentração de desse metal no cabelo. Tais diferenças foram explicadas pela presença de grande variedade de peixes consumidos e pertencentes a diferentes níveis tróficos. Com relação aos garimpeiros, foram encontrados maiores teores de mercúrio na urina do que no cabelo, o que é consistente com a alta exposição ocupacional ao vapor de mercúrio e o baixo consumo de peixes por esta população. A comparação dos níveis médios de mercúrio em cabelo $(17,2 \mu \mathrm{g} / \mathrm{g})$ das populações ribeirinhas do rio Madeira com os da população controle $(1,6 \mu \mathrm{g} / \mathrm{g})$, que consomem peixe apenas 2 a 3 vezes por mês, confirmou que o consumo de peixe é a principal fonte de mercúrio para o ser humano. Constataram ainda que a maioria das mulheres em idade fértil (54\%) apresentou teores de mercúrio em cabelo próximos a $10 \mu \mathrm{g} / \mathrm{g}$, limite acima do qual pode haver risco para o feto.

BOISCHIO e HENSHEL (1996) estimaram a ingestão de mercúrio em função da concentração encontrada no cabelo e da concentração nos peixes consumidos pela população ribeirinha do alto rio Madeira (RO). Com relação à ingestão estimada, os autores observaram que os valores encontrados a partir da ingestão de peixes subestimavam a ingestão, quando comparados aos valores calculados a partir dos teores encontrados nos cabelos das crianças. A ingestão média da população estudada estava acima do valor mínimo que pode causar parestesia para alguns grupos da população. Ainda, segundo os autores, as crianças com idade inferior a 15 anos são as mais sensíveis e aparentemente acumularam maiores quantidades de mercúrio. Com base nesse trabalho, os mesmos autores, numa segunda pesquisa, avaliaram os riscos da toxicidade do metilmercúrio para a mesma população ribeirinha do rio Madeira, a qual consome grandes quantidades de peixes. Estimando a ingestão média diária de mercúrio a partir da concentração média encontrada nos peixes, bem como no próprio consumo médio de peixe e comparando com o valor resultante da interconversão de mercúrio no cabelo em ingestão de mercúrio, observaram que estes dois valores eram iguais a $70 \mu \mathrm{g} / \mathrm{dia}$. A correspondência entre esses valores indica que a ingestão de mercúrio por esta população se dá primordialmente através do consumo de peixe. Através da avaliação de risco, os 
autores constataram que as crianças até 15 anos são a sub-população submetida ao risco mais alto.

Em julho e setembro de 1995 (época de seca ) e no período de março a maio de 1996 (época de chuva), o grupo de pesquisa do Departamento de Química da UFMT (Universidade Federal de Mato Grosso) fez um estudo na Baixada Cuiabana para avaliar o nível de contaminação de mercúrio nas populações ribeirinhas e nas espécies de peixes mais consumidas por essa população. Foram analisadas amostras de sangue, urina e cabelo da população humana, além de levantamento sobre consumo de pescado e efeitos clínicos e neuropsicológicos relacionados à exposição ao mercúrio. As análises compreenderam 54 espécimes de peixes na época da seca e 51 na época da chuva. As concentrações médias de mercúrio no peixe foram de $0,11 \mu \mathrm{g} / \mathrm{g}$ (não detectado a $0,49 \mu \mathrm{g} / \mathrm{g}$ ) na estação seca e $0,13 \mu \mathrm{g} / \mathrm{g}(0,01 \mu \mathrm{g} / \mathrm{g}$ a $0,68 \mu \mathrm{g} / \mathrm{g})$ na estação chuvosa. Dessas amostras, 36 espécimes na estação seca eram carnívoros, e apresentaram concentração média de mercúrio de $0,156 \mu \mathrm{g} / \mathrm{g}$, variando de $0,039 \mu \mathrm{g} / \mathrm{g}$ a $0,488 \mu \mathrm{g} / \mathrm{g}$. Na estação chuvosa, 28 espécimes eram carnívoros, cuja média de concentração de mercúrio foi de $0,211 \mu \mathrm{g} / \mathrm{g}$, variando de $0,050 \mu \mathrm{g} / \mathrm{g}$ a $0,680 \mu \mathrm{g} / \mathrm{g}$ (UFMT 1997).

Apesar de os níveis de mercúrio encontrados em peixes carnívoros no estudo do grupo da UFMT estarem abaixo do limite estabelecido pela legislação brasileira, que é de $1,00 \mathrm{mg} / \mathrm{kg}$, nesse mesmo estudo, 129 indivíduos adultos tiveram amostras de seus cabelos analisados em relação ao conteúdo de mercúrio. A média encontrada foi de 4,2 $\pm 2,4 \mu \mathrm{g} / \mathrm{g}$, e concentrações de mercúrio em cabelo acima do limite de referência da OMS para crianças e gestantes $(6 \mu \mathrm{g} / \mathrm{g})$ foram observadas em 25\% dos indivíduos (YOKOO 2001). Observou-se também, que 80\% da população amostrada apresentou níveis de mercúrio em cabelo acima dos $2 \mu \mathrm{g} / \mathrm{g}$, nível esperado para populações não expostas ao mercúrio.

Ainda no mesmo estudo, 92 amostras de sangue foram analisadas e a concentração média de mercúrio foi de 7,3 $\mu \mathrm{g} / \mathrm{L}$, variando de n.d. (não detectado) 
a $51,3 \mu \mathrm{g} / \mathrm{L}$, no período de seca. No período de chuva, 89 amostras de sangue foram analisadas e a concentração média foi de 9,2 $\mu \mathrm{g} / \mathrm{L}$, variando de n.d. a 92,3 $\mu \mathrm{g} / \mathrm{L}$. As concentrações de mercúrio em sangue de populações não expostas variam de 5 a $10 \mu \mathrm{g} / \mathrm{L}$. Os resultados desse estudo mostram que a fonte mais provável de contaminação por mercúrio nos indivíduos estudados é aquela proveniente da cadeia trófica, pelo consumo de pescado. Em relação ao consumo de pescado, considerando todas as espécies consumidas, o consumo médio de peixe foi de $109 \mathrm{~g}$ (0-379 g) na estação seca e $118 \mathrm{~g}(0-526 \mathrm{~g})$ na estação chuvosa. Nenhuma diferença estatisticamente significativa foi encontrada entre consumo médio de carnívoros ou omnívoros ou de outros peixes (considerando-se todos os hábitos alimentares) nas duas estações.

HYLANDER e col. (2000a) analisaram 185 amostras de peixes capturados nas partes sul e norte do Alto Pantanal, próximo à confluência dos rios Cuiabá e Paraguai e região de Cáceres e Barão de Melgaço. As concentrações de mercúrio nos peixes variaram de 0,04 a 2,05 mg/g. Das amostras analisadas, $90 \%$ tiveram concentrações de mercúrio abaixo de 0,5 ppm. Concentrações acima desse limite foram encontradas em amostras de Pseudoplatystoma e Serrasalmus capturadas na Baía Siá Mariana. Esta baía pertence à área CBA 2, onde também a média dos níveis de mercúrio em Serrasalmus (piranha) foi mais elevada no presente estudo. HYLANDER e col. (2000a) atribuem à característica levemente ácida das águas da baía as concentrações mais elevadas de mercúrio encontradas nos peixes capturados nessa região. 


\section{OBJETIVOS}

\subsection{Objetivo Geral}

Avaliar a evolução da contaminação mercurial em peixes no Alto Pantanal.

\subsection{Objetivos Específicos}

- Conhecer os níveis das concentrações de mercúrio em peixes, sedimento e material particulado em suspensão em diferentes pontos das baías ao longo dos rios Cuiabá, Paraguai e Bento Gomes, no Pantanal Mato-Grossense;

- Estabelecer correlações entre o conteúdo de mercúrio em peixes da espécie Serrasalmus spp. e o conteúdo de mercúrio em sedimento e material particulado em suspensão; e entre as concentrações de mercúrio e matéria orgânica no sedimento;

- Verificar a existência de diferenças espaciais entre as concentrações de mercúrio em piranhas (Serrasalmus spp.), no sedimento e em material particulado em suspensão; e

- Correlacionar os teores de mercúrio nas matrizes citadas com os teores encontrados em outros estudos feitos na região; a fim de avaliar a evolução dessa contaminação. 


\section{MATERIAL E MÉTODOS}

\subsection{Região de Abrangência do Estudo, Pontos de Coleta de Amostras e Período de Coleta de Amostras}

Os estudos e levantamentos foram desenvolvidos nos rios e baías Cuiabá, Paraguai e Bento Gomes (MT). As áreas onde foram coletadas as amostras encontram-se na Figura 3.

A coleta de amostras foi realizada no período de 04 de agosto a 15 de outubro de 2000 .

A Tabela 2 mostra a localização das áreas de coleta e os tipos de matrizes analisadas em cada área. 


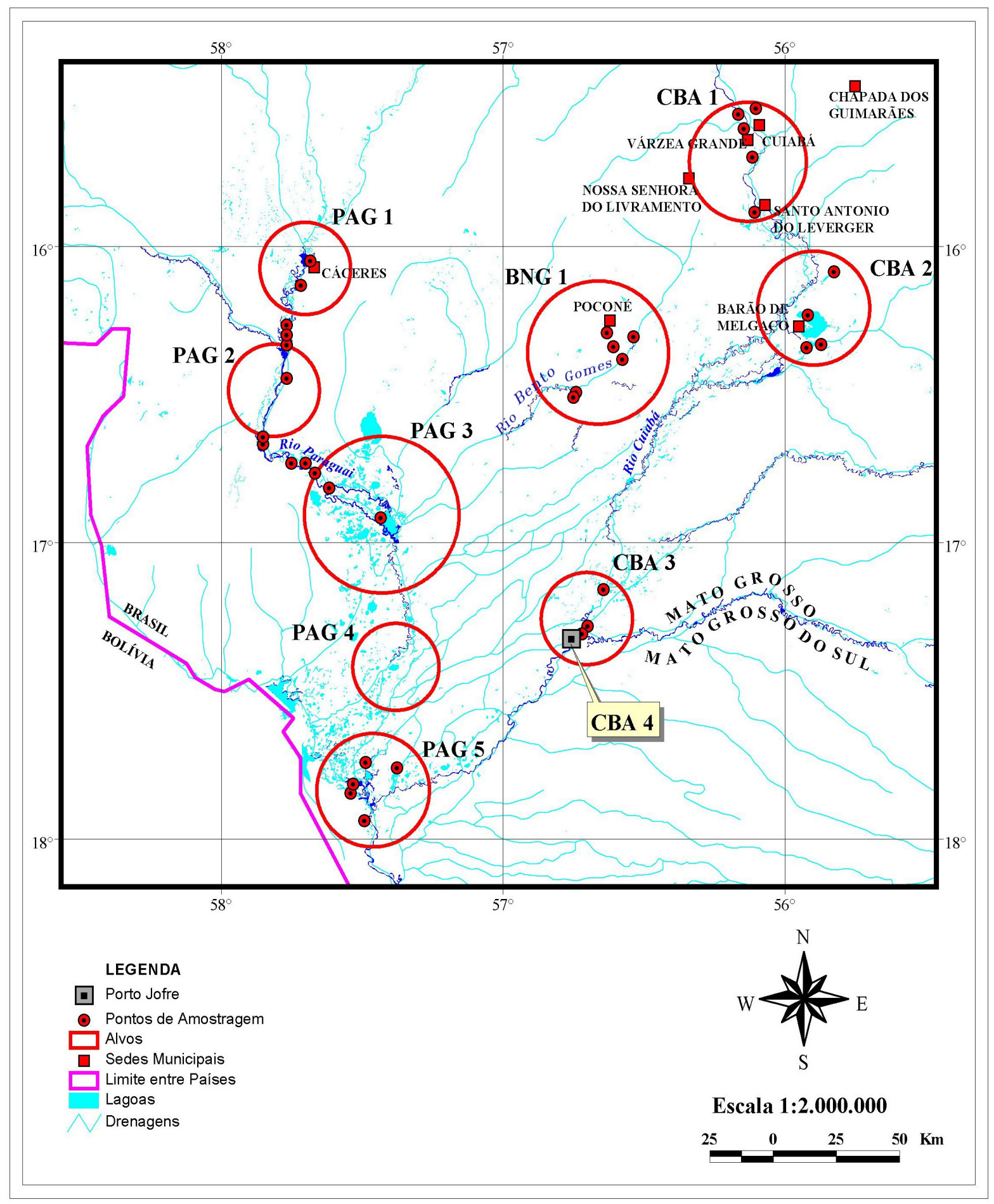

Figura 3 - Localização das áreas estudadas com os respectivos pontos de coleta. Bacia Alto Paraguai, Mato Grosso. 
Tabela 2 - Localização das áreas estudadas na região do Alto Pantanal, com as respectivas matrizes coletadas e analisadas em 2000.

\begin{tabular}{c|l|l}
\hline Área* & \multicolumn{1}{|c}{ Localidade } & \multicolumn{1}{|c}{ Matriz coletada } \\
\hline CBA 1 & $\begin{array}{l}\text { Rio Sucuri, Porto e Ponte JK (município } \\
\text { Cuiabá), Volta Grande e Baía da Laranja }\end{array}$ & $\begin{array}{l}\text { Sedimento e material particulado em } \\
\text { suspensão }\end{array}$ \\
\hline CBA 2 & $\begin{array}{l}\text { Baía Siá Mariana, Baía do Chacororé e } \\
\text { Baía do Porto de Fora }\end{array}$ & $\begin{array}{l}\text { Peixe, sedimento e material particulado em } \\
\text { suspensão }\end{array}$ \\
\hline CBA 3 & Rio Pingara, Rio Três Irmãos e Rio Piquiri & $\begin{array}{l}\text { Sedimento e material particulado em } \\
\text { suspensão }\end{array}$ \\
\hline CBA 4 & Porto Jofre & $\begin{array}{l}\text { Peixe, sedimento e material particulado em } \\
\text { suspensão }\end{array}$ \\
\hline BNG 1 & $\begin{array}{l}\text { Fazenda Conceição, Capão do Angico, } \\
\text { Cascalheira, Tanque dos Padres }\end{array}$ & $\begin{array}{l}\text { Peixe, sedimento e material particulado em } \\
\text { suspensão }\end{array}$ \\
\hline PAG 1 & Baía do Malheiros e Baía da Campina & Sedimento \\
\hline PAG 2 & $\begin{array}{l}\text { Confluência rios Jauru e Paraguai, Baía } \\
\text { do Galdino e Baía das Éguas }\end{array}$ & Sedimento \\
\hline PAG 3 & $\begin{array}{l}\text { Reserva Ecológica de Taiamã e Fazenda } \\
\text { Descalvado }\end{array}$ & Peixe e sedimento \\
\hline PAG 5 4 & $\begin{array}{l}\text { Rio Canafisto, Baía do Alegre, Rio Alegre } \\
\text { Nacional, Baía do Ingazá }\end{array}$ & $\begin{array}{l}\text { Peixe, sedimento e material particulado em } \\
\text { suspensão }\end{array}$ \\
\hline PAG - Rio Paraguai & $\begin{array}{l}\text { Peixe, sedimento e material particulado em } \\
\text { suspensão }\end{array}$ \\
\hline
\end{tabular}




\subsection{Matrizes e Parâmetros Analisados}

Foram coletadas amostras de sedimentos, material particulado em suspensão e peixes, que foram analisadas quanto às concentrações de mercúrio total, e no sedimento também foi determinada a concentração de matéria orgânica. Todas as análises foram realizadas nas dependências do laboratório de análise de Metais Pesados do Departamento de Química/UFMT.

As amostras de sedimento foram coletadas em duas profundidades, uma compreendeu uma camada de sedimento de até $10 \mathrm{~cm}$ de profundidade aproximadamente, e a outra correspondente a uma camada mais superficial, de $2 \mathrm{~cm}$. As amostras da camada de $10 \mathrm{~cm}$ foram coletadas com o auxílio de uma draga manual, Draga de Elkman. Este material, com aproximadamente 1,5 kg, foi acondicionado em sacos de polietileno, identificados, rotulados e preservados em caixas térmicas com gelo e posteriormente transportadas para o laboratório, onde foram mantidas sob refrigeração até o momento da análise. Foram coletadas 19 amostras de sedimento da camada de $2 \mathrm{~cm}$, obtidas próximos aos locais de coleta de sedimento da camada de $10 \mathrm{~cm}$. Para a obtenção das amostras da camada de $2 \mathrm{~cm}$ foi utilizado um perfilador tipo "corer" que permitiu após a coleta, a separação dos segmentos de $2 \mathrm{~cm}$.

Foram determinadas as concentrações de mercúrio em 18 amostras de material particulado em suspensão em águas das baías da Bacia do Alto Paraguai. As amostras de água foram coletadas em galões de polietileno com capacidade de vinte litros. Às amostras foram adicionadas, ainda em campo, solução de sulfato de alumínio $\left(\mathrm{AL}_{2}\left(\mathrm{SO}_{4}\right)_{3}\right)$ a $10 \%$ e de hidróxido de sódio $(\mathrm{NaOH}) 1 \mathrm{~N}$, com ajuste para $\mathrm{pH}=$ 7. As amostras foram então identificadas, rotuladas e transportadas para o laboratório; deixadas em repouso por 24 horas, quando então, era retirado de cada amostra o sobrenadante e, o concentrado de aproximadamente $500 \mathrm{~mL}$, era acondicionado em garrafas de polietileno com capacidade de 2 litros, que foram rotuladas e preservadas sob refrigeração até o momento da análise. 
Os peixes analisados foram os pertencentes ao topo da cadeia trófica de espécies predominantes no local (região) de estudo. As amostras eram das seguintes espécies de peixes predadores: Pseudoplatystoma fasciatum (cachara), Piniranpus pirinanpu (barbado), Pseudoplatystoma coruscans (pintado), Salminus maxillosus (dourado), Hemisorubin plathyrhynchos (jurupoca), Surubin lima (jurupensém) e Serrasalmus spp. (piranha). 


\subsection{Métodos Analíticos}

\subsubsection{Determinação de Mercúrio Total e Matéria Orgânica em Sedimento}

As amostras de sedimento foram secas em estufas, com temperatura inferior a $50^{\circ} \mathrm{C}$. Após a secagem, foram submetidas a peneiramento, sendo que somente a fração menor que $0,074 \mathrm{~mm}$ (200 mesh) era reservada para análise química.

Para a determinação do mercúrio foram utilizados 2,0 g de amostra $(<0,074 \mathrm{~mm})$, digerida segundo o método proposto por GONÇALVES E PAIVA (1995). Em tubo de ensaio longo, com dedo frio para evitar a perda de amostra por evaporação, foi adicionada uma alíquota de até $0,5 \mathrm{~g}$ da amostra (dependendo da massa total obtida), $7 \mathrm{ml}$ de ácido clorídrico - $\mathrm{HCl}$ (concentrado) e $3 \mathrm{ml}$ de ácido nítrico - HNO3 (concentrado). A mistura foi aquecida em bloco digestor a $80^{\circ} \mathrm{C}$ por 30 minutos, depois, por mais uma hora a $120^{\circ} \mathrm{C}$. Após o aquecimento, deixava-se a solução esfriar e acrescentava-se à mesma mais $10 \mathrm{~mL}$ de água deionizada e, em seguida, procedia-se às leituras. O teor de mercúrio foi determinado por CVAAS (Gerador de hidretos VGA 77 da Varian acoplado a um AAS Varian 220), utilizando como redutor o cloreto estanoso em meio ácido.

A determinação do teor de matéria orgânica em sedimento foi realizada pelo método de WALKLEY e BLACK (1934), que se baseia na oxidação da matéria orgânica contida na amostra por dicromato de potássio, em meio sulfúrico.

O controle das análises de mercúrio foi conferida por meio da comparação com materiais de referência certificados (GBW 07309 sedimento de fluxo com 83 ng $\mathrm{Hg} / \mathrm{g}$, NIST 2704 com $1470 \mathrm{ng} \mathrm{Hg/g).} \mathrm{A} \mathrm{precisão} \mathrm{de} \mathrm{todas} \mathrm{as} \mathrm{análises} \mathrm{foi} \mathrm{verificada}$ por padrões internos e análises em duplicatas. O limite de detecção (3 SD) para mercúrio foi de $0.5 \mu \mathrm{g} / \mathrm{L}$ no extrato, e $5 \mathrm{ng} / \mathrm{g}$ de peso seco, no sedimento, quando 
usado $2 \mathrm{~g}$ de amostra e um volume final de $20 \mathrm{~mL}$. A precisão (1 SD) foi ao redor de $10 \%$ em amostras típicas que contêm $10-100 \mathrm{ng} / \mathrm{g}$ de peso seco.

\subsubsection{Determinação de Mercúrio Total em Material Particulado em Suspensão}

Para a preparação da amostra de material particulado em suspensão (MPS) para análise do teor de mercúrio, o concentrado, após ambientação à temperatura do laboratório, foi centrifugado a 2000 rpm por 5 minutos, em centrífuga Fanen modelo Baby. O resíduo pastoso foi colocado para secar em estufa em temperatura inferior a $50^{\circ} \mathrm{C}$. Depois de seco, foi realizada a desagregação do resíduo sólido, com pistilo em gral de porcelana. O pó obtido foi acondicionado em dessecador.

A digestão da amostra foi feita segundo o método proposto por GONÇALVES e PAIVA (1995). Em tubo de ensaio longo, com dedo frio para evitar a perda de amostra por evaporação, foi adicionada uma alíquota de até $0,5 \mathrm{~g}$ (dependendo da massa total obtida), $7 \mathrm{ml}$ ácido clorídrico $(\mathrm{HCl})$ concentrado e $3 \mathrm{ml}$ de ácido nítrico $\left(\mathrm{HNO}_{3}\right)$ concentrado. A mistura foi aquecida em bloco digestor a $80^{\circ} \mathrm{C}$ por 30 minutos, depois por mais uma hora a $120^{\circ} \mathrm{C}$. Após o aquecimento, deixava-se a solução esfriar e acrescentava-se à mesma mais $10 \mathrm{~mL}$ de água deionizada e, em seguida, procediam-se às leituras. $\mathrm{O}$ teor de mercúrio foi determinado por CVAAS (Gerador de hidretos VGA 77 da Varian acoplado a um AAS Varian 220), utilizando como redutor o cloreto estanoso em meio ácido.

\subsubsection{Determinação de Mercúrio Total em Peixes}

\subsubsection{Coleta e Preparação das Amostras de Peixes}

Espécimes de peixes foram capturados por pescadores locais, que foram contratados com este propósito, ou pela própria equipe de pesquisa, utilizando-se instrumentos de pesca convencional, como anzóis e linhas. Ainda em campo, foram retirados cerca de cinco gramas do músculo lateral. Essa porção era então acondicionada em saco plástico e mantida sob refrigeração em caixa isolante contendo gelo para o transporte 
até o laboratório. No laboratório, os pedaços foram triturados em triturador de alimentos e misturados até a completa homogeneização. As frações para determinação de mercúrio total foram tomadas da amostra homogeneizada.

\subsubsection{Digestão e Leitura das Amostras de Peixes}

Da amostra previamente homogeneizada, 1,0 g foi pesado e colocado em tubo de ensaio com dedo frio para a abertura. A digestão foi realizada com $10 \mathrm{~mL}$ de água régia (2 partes de ácido nítrico concentrado para 1 parte de ácido clorídrico concentrado), em banho-maria por 1 hora em temperatura entre 70 e $80^{\circ} \mathrm{C}$. A leitura do teor de mercúrio foi realizada em espectrofotômetro de absorção atômica, modelo ESPECTRA 220 da Varian, com a utilização de gerador de hidretos modelo VG 77.

\subsubsection{Controle de Qualidade para Determinação de Mercúrio Total em Peixes}

Todas as determinações de mercúrio total em amostras de peixes foram controladas pela comparação com leituras paralelas de amostras certificadas de peixes "Dogfish Muscle and liver Certified Reference Material for Trace Metals of the National Research Council Canada, sample DORM-2", bem como de amostras padrões internos. Os padrões internos foram preparados a partir de um exemplar de peixe grande, o qual foi totalmente triturado e separado em pequenas porções, as quais foram analisadas juntamente com todos os lotes de amostras do projeto. 


\subsection{Análise Estatística dos Dados}

Após a verificação de consistência e correção de possíveis erros de digitação, os dados relativos às concentrações de mercúrio em peixe, sedimento e material particulado em suspensão foram sumariados e apresentados em forma de tabelas e gráficos. Foram estimadas as médias e desvios-padrão dos níveis de mercúrio dessas amostras.

Foi testada a normalidade da distribuição dos dados das variáveis estudadas, pelo teste de Shapiro-Wilk, sendo que nenhuma das variáveis apresentou distribuição normal, o que justificou a aplicação de testes não-paramétricos na análise estatística dos dados.

Nas análises estatísticas, foram utilizados apenas os dados de mercúrio em piranhas (Serrasalmus spp.), pois essa espécie foi a que teve maior representatividade nas áreas de coleta de amostras.

Para verificar a existência de diferença entre as concentrações de mercúrio nas matrizes analisadas segundo local de coleta foram aplicados os testes de KruskalWallis e de Mann-Whitney.

O teste de correlação de Spearman foi aplicado para verificar a existência de correlação entre as variáveis.

As análises estatísticas foram realizadas utilizando o programa SPSS 9.0. 


\section{RESULTADOS}

\subsection{Mercúrio Total nas Amostras de Peixes}

Foram analisadas, quanto ao conteúdo de mercúrio total, 74 amostras de peixes pertencentes a sete espécies, distribuídas em 6 áreas da região de estudo. Os resultados das análises estão na Tabela 3 e Figura 4.

O número de amostras (n) variou muito entre as espécies. A espécie Serrasalmus spp. (piranha) é a que apresentou o maior n, 44 amostras. As concentrações de mercúrio total considerando todas as espécies analisadas também tiveram grande variação, de $0,02 \mu \mathrm{g} / \mathrm{g}$ a $0,80 \mu \mathrm{g} / \mathrm{g}$. As espécies que apresentaram os valores mais altos de mercúrio foram barbado e dourado, mas destaca-se o número muito reduzido de amostras, 02 e 01 respectivamente.

A Tabela 4 apresenta os dados de concentração de mercúrio nas espécies estudadas, agrupadas por área de coleta. Tendo em vista o reduzido número de amostras das diferentes espécies e que essas não foram coletadas em todas as áreas, decidiu-se analisar a distribuição das concentrações de mercúrio apenas nas piranhas. Foram analisadas 44 amostras de piranha que foram capturadas em todas as áreas de coleta de amostras de peixes. Não foi possível incluir na análise, os dados de biometria das piranhas devido a falta desses dados para todos os espécimes capturados. 
Tabela 3 - Distribuição das concentrações de mercúrio total $(\mu \mathrm{g} / \mathrm{g})$ em peixes das áreas estudadas do Alto Pantanal, segundo espécie.

\begin{tabular}{|c|c|c|c|c|}
\hline Espécie & $n$ & $\begin{array}{c}\text { Média } \\
\pm \mathrm{DP}(\mu \mathrm{g} / \mathrm{g}) \\
\end{array}$ & Mínimo & Máximo \\
\hline $\begin{array}{l}\text { Pseudoplatystoma } \\
\text { fasciatum (cachara) }\end{array}$ & 18 & $0,21 \pm 0,20$ & 0,06 & 0,80 \\
\hline $\begin{array}{l}\text { Piniranpus pirinanpu } \\
\text { (barbado) }\end{array}$ & 02 & $0,72 \pm 0,08$ & 0,06 & 0,77 \\
\hline $\begin{array}{l}\text { Pseudoplatystoma } \\
\text { coruscans (pintado) }\end{array}$ & 07 & $0,18 \pm 0,19$ & 0,07 & 0,59 \\
\hline $\begin{array}{l}\text { Salminus maxillosus } \\
\text { (dourado) }\end{array}$ & 01 & 0,72 & --- & --- \\
\hline $\begin{array}{l}\text { Hemisorubin } \\
\text { plathyrhynchos } \\
\text { (jurupoca) }\end{array}$ & 01 & 0,05 & --- & --- \\
\hline $\begin{array}{l}\text { Surubin lima } \\
\text { (jurupensém) }\end{array}$ & 01 & 0,30 & --- & --- \\
\hline $\begin{array}{c}\text { Serrasalmus spp. } \\
\text { (piranha) }\end{array}$ & 44 & $0,16 \pm 0,12$ & 0,02 & 0,50 \\
\hline Total & 74 & $0,19 \pm 0,18$ & 0,02 & 0,80 \\
\hline
\end{tabular}




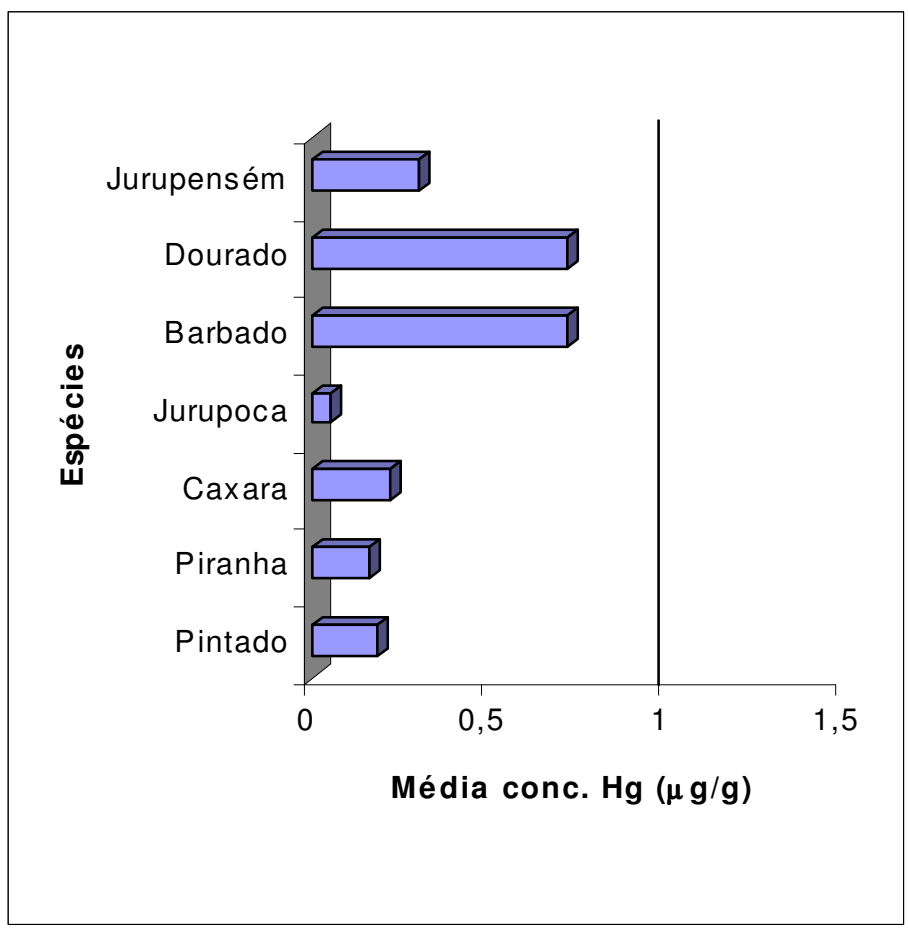

Figura 4 - Médias das concentrações de mercúrio total $(\mu \mathrm{g} / \mathrm{g})$ em peixes, segundo espécie, e limite máximo permitido da concentração de mercúrio na musculatura de peixes predadores no Brasil, de 1,0 $\mu \mathrm{g} / \mathrm{g}$ (BRASIL 1998). 
Tabela 4 - Concentrações de mercúrio total $(\mu \mathrm{g} / \mathrm{g})$ nas diferentes espécies de peixes analisados, segundo área de coleta.

\begin{tabular}{|c|c|c|c|c|c|}
\hline \multirow{2}{*}{$\begin{array}{c}\text { Área de } \\
\text { coleta* }\end{array}$} & \multirow[b]{2}{*}{ Espécie } & \multirow[b]{2}{*}{$\mathbf{n}$} & \multicolumn{3}{|c|}{ Concentração de mercúrio $(\mu \mathrm{g} / \mathrm{g})$} \\
\hline & & & Média \pm DP & mín. & máx. \\
\hline \multirow{7}{*}{ CBA 2} & $\begin{array}{c}\text { Pseudoplatystoma fasciatum } \\
\text { (Cachara) }\end{array}$ & 04 & $0,45 \pm 0,29$ & 0,13 & 0,80 \\
\hline & Piniranpus pirinanpu (Barbado) & 02 & $0,72 \pm 0,06$ & 0,66 & 0,77 \\
\hline & Serrasalmus spp. (Piranha) & 17 & $0,24 \pm 0,12$ & 0,11 & 0,50 \\
\hline & $\begin{array}{l}\text { Pseudoplatystoma coruscans } \\
\text { (Pintado) }\end{array}$ & 04 & $0,21 \pm 0,22$ & 0,07 & 0,59 \\
\hline & Salminus maxillosus (Dourado) & 01 & 0,72 & --- & --- \\
\hline & $\begin{array}{l}\text { Hemisorubin plathyrhynchos } \\
\text { (Jurupoca) }\end{array}$ & 01 & 0,05 & --- & --- \\
\hline & Surubin lima (Jurupensém) & 01 & 0,30 & --- & --- \\
\hline CBA 4 & Serrasalmus spp. (Piranha) & 01 & 0,41 & --- & --- \\
\hline \multirow[t]{2}{*}{ BNG 1} & $\begin{array}{c}\text { Pseudoplatystoma fasciatum } \\
\text { (Cachara) }\end{array}$ & 03 & $0,20 \pm 0,03$ & 0,17 & 0,25 \\
\hline & Serrasalmus spp. (Piranha) & 05 & $0,10 \pm 0,02$ & 0,06 & 0,13 \\
\hline PAG 3 & Serrasalmus spp. (Piranha) & 04 & $0,08 \pm 0,02$ & 0,05 & 0,10 \\
\hline PAG 4 & Serrasalmus spp. (Piranha) & 07 & $0,14 \pm 0,05$ & 0,09 & 0,21 \\
\hline \multirow{3}{*}{ PAG 5} & Serrasalmus spp. (Piranha) & 10 & $0,05 \pm 0,03$ & 0,02 & 0,11 \\
\hline & $\begin{array}{c}\text { Pseudoplatystoma coruscans } \\
\text { (Pintado) }\end{array}$ & 03 & $0,13 \pm 0,01$ & 0,12 & 0,14 \\
\hline & $\begin{array}{l}\text { Pseudoplatystoma fasciatum } \\
\text { (Cachara) }\end{array}$ & 11 & $0,13 \pm 0,06$ & 0,07 & 0,24 \\
\hline \multicolumn{6}{|c|}{$\begin{array}{l}\text { *CBA } 2 \text { - Rio Cuiabá: baía Siá Mariana, baía do Chacororé e baía do Porto de Fora } \\
\text { CBA } 4 \text { - Rio Cuiabá: Porto Jofre } \\
\text { BNG } 1 \text { - Rio Bento Gomes: Fazenda Conceição, Capão do Angico, Fazenda Ipiranga, Fazenda São } \\
\text { Vicente, Cascalheira, Tanque dos Padres } \\
\text { PAG } 3 \text { - Rio Paraguai: Reserva Ecológica de Taiamã e Fazenda Descalvado } \\
\text { PAG } 4 \text { - Rio Paraguai: Rio Canafisto, baía do Alegre, rio Alegre } \\
\text { PAG } 5 \text { - Rio Paraguai: Baía do Burro, baía Acorizal, Parque Nacional, baía do Ingazá } \\
\text { n = número de amostras } \\
\text { DP = desvio padrão } \\
\text { Md = mediana } \\
\text { Mín. = valor mínimo } \\
\text { Máx. = valor máximo } \\
\text {--- = não se aplica }\end{array}$} \\
\hline
\end{tabular}


A distribuição das concentrações de mercúrio em piranhas, segundo área de coleta (Tabela 5 e Figura 5), indicou que aparentemente a média das piranhas foi maior na área CBA 2, excluindo-se a área CBA 4 onde analisou-se apenas um indivíduo.

Para verificar se a distribuição das concentrações de mercúrio em piranha era normal, aplicou-se o teste de Shapiro-Wilk. Duas áreas não apresentaram distribuição normal, CBA 2 e PAG $5\left(W_{\mathrm{CBA} 2}=0,875, p=0,028 ; W_{\mathrm{PAG} 5}=0,828, p=0,039\right)$. Portanto, foi utilizado o teste não-paramétrico de Kruskal-Wallis para testar se havia diferença entre as concentrações de mercúrio dos grupos de piranha segundo local de coleta.

O teste de Kruskal-Wallis indicou que os grupos de piranhas das diferentes áreas de coleta diferiam entre si quanto ao conteúdo de mercúrio, com valor de $\mathrm{H}=32,896$, $\mathrm{gl}=5$ e $p<0,001$.

Tabela 5 - Concentrações de mercúrio total $(\mu \mathrm{g} / \mathrm{g})$ em piranhas, segundo local de coleta.

\begin{tabular}{ccccc}
\hline $\begin{array}{c}\text { Área de } \\
\text { coleta }\end{array}$ & $\mathbf{n}$ & Média $\pm \mathbf{D P}(\boldsymbol{\mu g} / \mathbf{g})$ & Mín. & Máx \\
\hline CBA 2 & 17 & $0,24 \pm 0,13$ & 0,11 & 0,50 \\
CBA 4 & 1 & 0,41 & --- & --- \\
BNG 1 & 5 & $0,10 \pm 0,03$ & 0,06 & 0,13 \\
PAG 3 & 4 & $0,08 \pm 0,02$ & 0,05 & 0,10 \\
PAG 4 & 7 & $0,14 \pm 0,05$ & 0,09 & 0,21 \\
PAG 5 & 10 & $0,05 \pm 0,03$ & 0,02 & 0,11 \\
\hline Total & 44 & $0,16 \pm 0,12$ & 0,02 & 0,50 \\
\hline
\end{tabular}




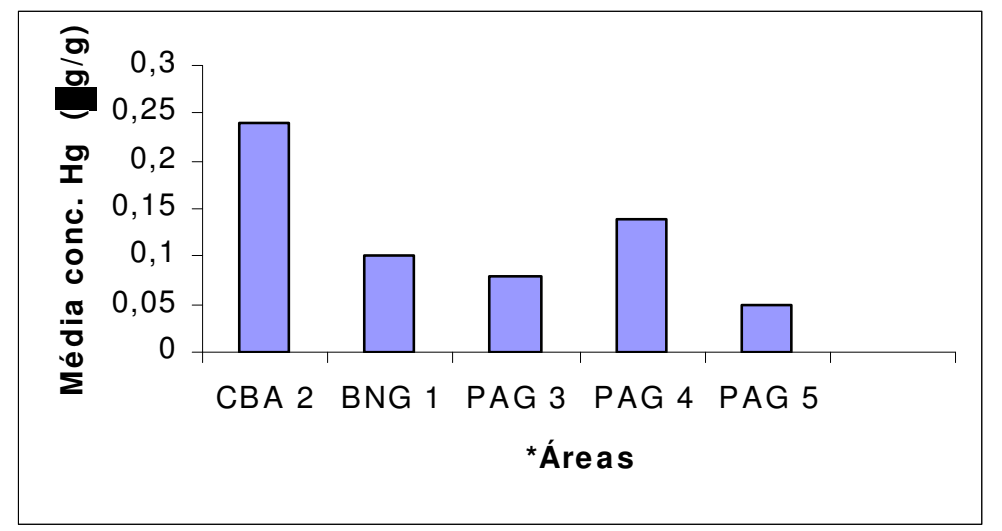

${ }^{*}$ CBA 4 excluída por apresentar apenas um indivíduo

Figura 5 - Distribuição das médias das concentrações de mercúrio total $(\mu \mathrm{g} / \mathrm{g})$ em piranhas, segundo área de coleta.

Foi feito o teste de Mann-Whitney (nível de significância de 5\%) para comparação entre os grupos de piranhas, de 2 em 2 áreas, para saber quais diferem, já que o teste de Kruskal- Wallis indicou diferença entre os grupos.

As concentrações de mercúrio em piranha mostraram ser mais elevadas na área CBA 2 do que nas áreas BNG $1(p=0,003)$, PAG $3(p=0,002)$ e PAG $5(p<0,001)$. As áreas BNG 1 e PAG 5 também mostraram ser diferentes entre si $(p=0,011)$, e também as concentrações foram diferentes entre as áreas PAG 4 e PAG $5(p=0,001)$. 


\subsection{Mercúrio Total nas Amostras de Sedimento}

A Tabela 6 mostra as concentrações de mercúrio total nas amostras de sedimento das camadas de 0-10 $\mathrm{cm}$ e de 0-2 $\mathrm{cm}$ de profundidade. Para a análise de sedimento da camada de 0-10 cm foram realizadas coletas de amostras em dez áreas da região do Alto Pantanal (Tabela 1), mas para sedimento de profundidade de 0-2 cm, em apenas oito áreas . Os dados mostram pouca variação das concentrações de mercúrio nas áreas estudadas.

Tabela 6 - Concentrações de mercúrio $(\mu \mathrm{g} / \mathrm{g})$ no sedimento do Alto Pantanal, segundo local de coleta

\begin{tabular}{cccccc}
\hline $\begin{array}{c}\text { Área de } \\
\text { coleta }\end{array}$ & $\mathbf{n}$ & $\begin{array}{c}\text { Média do sedimento } \\
\mathbf{0 - 1 0} \mathbf{~ c m} \pm \mathbf{D P}\end{array}$ & Mín. & Máx. & $\begin{array}{c}\text { Média do } \\
\text { sedimento } \mathbf{0 - 2} \mathbf{~ c m}\end{array}$ \\
\hline CBA 1 & 5 & $0,03 \pm 0,02$ & 0,005 & 0,05 & --- \\
CBA 2 & 5 & $0,03 \pm 0,01$ & 0,03 & 0,05 & 0,06 \\
CBA 3 & 3 & $0,02 \pm 0,01$ & 0,01 & 0,03 & --- \\
CBA 4 & 2 & $0,05 \pm 0,02$ & 0,04 & 0,07 & 0,02 \\
BNG 1 & 11 & $0,04 \pm 0,03$ & 0,01 & 0,11 & 0,05 \\
PAG 1 & 4 & $0,05 \pm 0,02$ & 0,03 & 0,07 & 0,07 \\
PAG 2 & 9 & $0,06 \pm 0,03$ & 0,01 & 0,11 & 0,05 \\
PAG 3 & 5 & $0,05 \pm 0,01$ & 0,03 & 0,05 & 0,06 \\
PAG 4 & 2 & $0,03 \pm 0,02$ & 0,01 & 0,05 & 0,03 \\
\hline PAG 5 & 6 & $0,04 \pm 0,02$ & 0,02 & 0,08 & 0,03 \\
\hline Total & 52 & $0,04 \pm 0,03$ & 0,01 & 0,11 & 0,05 \\
\hline
\end{tabular}

Para testar a diferença entre os grupos, aplicou-se o teste de Kruskal-Wallis. O teste indicou que não existe diferença significativa (nível de significância de 5\%) entre as concentrações de mercúrio nas amostras de sedimento dos diferentes locais de coleta. Para as concentrações de mercúrio em sedimento de 0-10 cm, o valor para $\mathrm{H}$ foi 
11,456, $\mathrm{gl}=9$ e $p=0,246$, e para o sedimento de $0-2 \mathrm{~cm}$, o valor para $\mathrm{H}$ foi 8,825 , $\mathrm{gl}=7$ e $p=0,265$. 


\subsection{Mercúrio Total em Material Particulado em Suspensão de Amostras de Água}

Foram analisadas somente 18 (dezoito) amostras de material particulado em suspensão, em apenas 7 áreas da região do Alto Paraguai. As concentrações de mercúrio total nessas amostras estão sumarizadas na Tabela 7 e Figura 6.

Tabela 7 - Concentrações de mercúrio total $(\mu \mathrm{g} / \mathrm{g})$ em amostras de material particulado em suspensão em águas das baías da Bacia do Alto Paraguai, segundo local de coleta.

\begin{tabular}{llcll}
\hline Área $^{*}$ & $\mathbf{n}$ & $\begin{array}{c}\text { Média } \\
(\mu \mathbf{g} / \mathbf{g})\end{array}$ & Min. & Máx. \\
\hline CBA 1 & 5 & 0,05 & 0,02 & 0,09 \\
CBA 2 & 2 & 0,05 & 0,04 & 0,05 \\
CBA 3 & 2 & 0,10 & 0,06 & 0,14 \\
BNG 1 & 5 & 0,03 & 0,02 & 0,04 \\
PAG 5 & 2 & 0,04 & 0,02 & 0,05 \\
\hline
\end{tabular}

*As áreas CBA 4 e PAG 4 não foram incluídas porque ambas apresentaram $n=1$

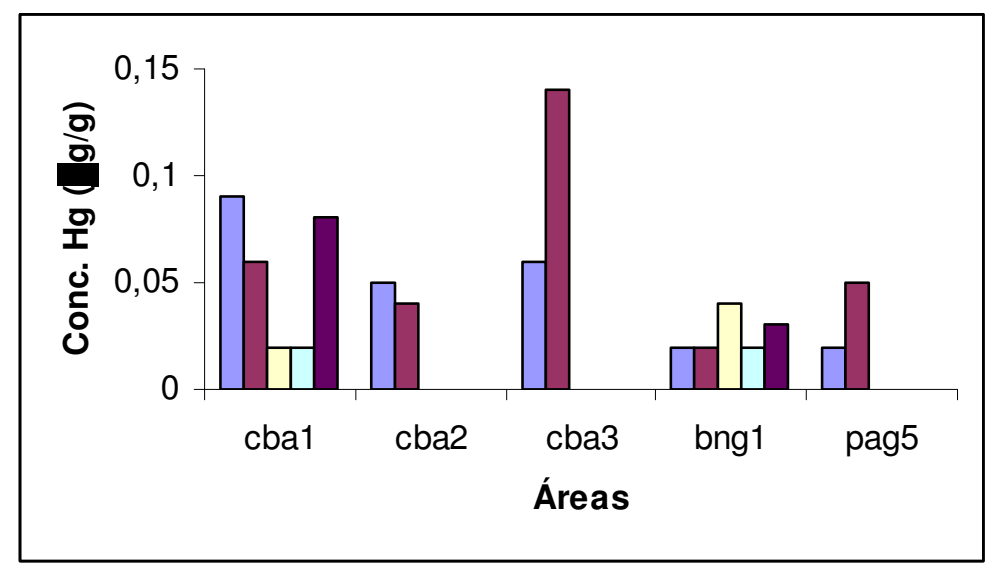

Figura 6 - Concentrações de mercúrio total $(\mu \mathrm{g} / \mathrm{g})$ em material particulado em suspensão em amostras de água, segundo área de coleta. As barras verticais representam cada amostra analisada.

A área CBA 3 (Fig. 6) foi a que apresentou as maiores concentrações de mercúrio em material particulado em suspensão. Porém, o teste de Kruskal-Wallis indicou que não 
há diferença estatisticamente significativa entre as concentrações de mercúrio no material particulado nas áreas estudadas. 


\subsection{Correlação entre as variáveis estudadas}

Foi aplicado o teste de correlação de Spearman para verificar a existência de correlação entre a variável mercúrio em piranha e as variáveis mercúrio em sedimento 0-10 cm, mercúrio em sedimento 0-2 $\mathrm{cm}$ e em material particulado em suspensão; a correlação entre concentração de mercúrio e concentração de matéria orgânica no sedimento $0-10 \mathrm{~cm}$; e também a correlação entre as concentrações de mercúrio em sedimento 0-10 cm e em material particulado em suspensão. A Tabela 8 mostra o relacionamento dessas variáveis.

O teste de Spearman encontrou correlação positiva entre concentração de mercúrio em piranha e concentração de mercúrio em material particulado em suspensão e em sedimento 0-2 cm, apesar de que não foram considerados na análise os dados de peso, tamanho e idade dos peixes. Não houve correlação estatisticamente significativa entre concentração de mercúrio em sedimento $0-10 \mathrm{~cm}$ e material particulado em suspensão; e entre concentração de mercúrio em sedimento 0-10 cm e concentração de matéria orgânica.

Houve correlação estatisticamente significativa, porém negativa, entre mercúrio em piranha e mercúrio em sedimento $0-10 \mathrm{~cm}$. 
Tabela 8 - Correlações entre as variáveis mercúrio em piranha, mercúrio em sedimento 0-10 cm, mercúrio em sedimento 0-2 cm, mercúrio em material particulado em suspensão; correlação entre mercúrio em sedimento $0-10 \mathrm{~cm}$ e em material particulado em suspensão e conteúdo de matéria orgânica.

\begin{tabular}{cccc}
\hline Correlação & $\mathbf{n}$ & $\begin{array}{c}\text { Coef. de } \\
\text { Spearman ( } \boldsymbol{\rho})\end{array}$ & $\boldsymbol{p}$ \\
\hline $\begin{array}{c}\text { Hg em piranha e Hg em } \\
\text { sedimento } 0-10 \mathrm{~cm}\end{array}$ & 44 & $-0,711$ & $<0,001$ \\
$\begin{array}{c}\mathrm{Hg} \text { em piranha e Hg em } \\
\text { sedimento 0-2 cm }\end{array}$ & 44 & 0,459 & 0,002 \\
$\begin{array}{c}\text { Hg em piranha e Hg em } \\
\text { material particulado }\end{array}$ & 40 & 0,561 & $<0,001$ \\
$\begin{array}{c}\text { Hg em sedimento 0-10 cm e } \\
\text { material particulado em } \\
\text { suspensão }\end{array}$ & 15 & $-0,100$ & 0,723 \\
$\begin{array}{c}\text { Hg em sedimento 0-10 cm e } \\
\text { concentração de matéria } \\
\text { orgânica }\end{array}$ & 35 & 0,085 & 0,626 \\
\hline
\end{tabular}




\section{DISCUSSÃO}

\subsection{Mercúrio em peixes}

As sete espécies de peixes carnívoros estudadas, Pseudoplatystoma fasciatum (cachara), Piniranpus pirinanpu (barbado), Serrasalmus spp. (piranha), Pseudoplatystoma coruscans (pintado), Salminus maxillosus (dourado), Hemisorubin plathyrhynchos (jurupoca) e Surubin lima (jurupensém), são espécies de importância na região do Alto Pantanal sob o aspecto de consumo humano e em relação à posição que ocupam na cadeia alimentar. Por pertencerem ao topo da cadeia trófica, a probabilidade de acumulação de mercúrio nesses organismos é maior.

No entanto, as dificuldades na obtenção de espécimes de peixes pertencentes a essas sete espécies em todas as áreas de abrangência do estudo fez com que a amostragem de pescado ficasse restrita a poucas espécies em cada área e a um número muito reduzido de amostras. A conseqüência foi uma distribuição não eqüitativa de espécies e espécimes nas seis áreas onde houve coleta de peixes, o que tornou as áreas muito heterogêneas para realizar uma avaliação de contaminação por mercúrio, além de que não havia dados de biometria de todos os peixes capturados (Tabela 4).

Decidiu-se pois, analisar os resultados das concentrações de mercúrio somente em piranhas (Serrasalmus spp.), já que esta espécie é a que apresentou maior representatividade em todas as áreas. Também, sendo a piranha um peixe de pouca importância econômica, acaba por constituir uma das espécies mais consumidas pela população ribeirinha local (YOKOO 2001).

A piranha tem hábitos carnívoros e oportunísticos e é uma espécie migratória que se desloca em cardumes de 20 a 30 indivíduos (SAZIMA e MACHADO 1990). A análise do conteúdo estomacal dessa espécie mostra que elas comem peixes, répteis, insetos, crustáceos, moluscos e plantas aquáticas. Portanto, a piranha, pelo seu hábito alimentar e por viver preferencialmente em ambientes de baixo hidrodinamismo 
(lênticos) (SAZIMA e MACHADO 1990), pode ser um bom indicador da contaminação do ambiente em que vive.

Com as ressalvas acima expostas, se observarmos os resultados de concentração em todas as espécies, ainda assim o limite estabelecido pela legislação brasileira de mercúrio total em peixes predadores de $1,00 \mu \mathrm{g} / \mathrm{g}$ não foi ultrapassado em nenhuma das amostras. Porém, esse valor deve ser observado com cuidado pois, dependendo do consumo de pescado pela população, valores como os encontrados nas espécies de barbado e dourado poderiam causar algum efeito prejudicial para a saúde humana.

As concentrações de mercúrio total em piranhas variaram de $0,02 \mu \mathrm{g} / \mathrm{g}$ a $0,50 \mu \mathrm{g} / \mathrm{g}$. Os valores mais altos foram encontrados nas áreas CBA 2, CBA 4, PAG 4.

LACERDA (1991) encontrou concentrações bem mais baixas em piranhas das espécies Serrasalmus eigenmans, Serrasalmus rhombeus e Serrasalmus nattereri; as quais variaram de 0,04 a $0,06 \mu \mathrm{g} / \mathrm{g}$ no rio Bento Gomes. $\mathrm{O}$ autor sugere que as baixas concentrações encontradas sejam devidas às características do ponto de amostragem no rio Bento Gomes, cuja vazão é muito alta, com grande poder de diluição, e que o mercúrio transportado encontra-se associado ao material particulado, eficientemente retido (depositado) pelos vários lagos, artificiais ou não, presentes ao longo da drenagem (LACERDA 1991).

HYLANDER e col. (2000a), em estudo realizado no ano de 1998 na região do Alto Pantanal, encontraram concentrações de mercúrio nos peixes que variaram de 0,04 a 2,05 $\mu \mathrm{g} / \mathrm{g}$. Das amostras analisadas, 90\% tiveram concentrações de mercúrio abaixo de 0,5 ppm. Os valores de mercúrio mais elevados foram encontrados em peixes das espécies Pseudoplatystoma e Serrasalmus na Baía Siá Mariana, concentrações acima de $0,50 \mu \mathrm{g} / \mathrm{g}$. As concentrações de mercúrio na espécie Serrasalmus spp. variaram de 0,05 a $0,50 \mu \mathrm{g} / \mathrm{g}$ na época chuvosa e de 0,07 a 2,05 $\mu \mathrm{g} / \mathrm{g}$ na época de seca. Essa baía pertence à área CBA 2, onde também a média dos níveis de Hg em Serrasalmus (piranha) foi mais elevada no presente estudo. 
Segundo os mesmos autores, a Baía Siá Mariana, devido às características de suas águas, tais como pH mais ácido, pouca quantidade de material particulado em suspensão e íons dissolvidos, levam à dissolução da matéria orgânica. Esse tipo de água, como também as águas escuras com alto conteúdo de carbono orgânico, é conhecida por aumentar a mobilidade e provavelmente também a biodisponibilidade de mercúrio (MEILI 1991, 1997 citado por HYLANDER e col. 2000a).

As características das águas citadas acima foram encontradas em águas das baías da área CBA 2 (Baía Siá Mariana, Baía do Chacororé e Baía do Porto de Fora) no estudo do projeto GEF (UFMT 2002), na mesma campanha de obtenção dos dados aqui analisados. O pH nessas baías, inclusive Siá Mariana, variou de 5,50 a 7,42.

HYLANDER e col. (1994) realizaram um outro estudo em 1992 também na região do Alto Paraguai, porém os pontos de coleta estavam localizados nas drenagens nos cursos dos rios Cuiabá e Paraguai. Os níveis de mercúrio em peixes variaram de 0,05 a $0,95 \mu \mathrm{g} / \mathrm{g}$ em pintado e de 0,09 a $0,51 \mu \mathrm{g} / \mathrm{g}$ em piranha. Nota-se que os níveis de mercúrio no estudo de 1992 foram mais baixos do que os encontrados em 1998 (HYLANDER e col. 2000a). Segundo os autores, essa diferença é devida às características da água de lagos, como a das baías do Pantanal, que, por ser pouco misturada, mais parada, as concentrações de mercúrio em peixe têm uma variação maior naquelas espécies que preferem ambientes lênticos, como as piranhas.

No presente estudo foi encontrado o valor de $0,41 \mu \mathrm{g} / \mathrm{g}$ na área CBA 4 (Porto Jofre), mas analisou-se apenas um espécime de piranha. Nos dois estudos anteriores, na mesma região (HYLANDER e col. 1994, 2000a), foram também encontrados níveis de mercúrio em piranhas mais altos em Porto Jofre. Esses estudos mostraram um aumento nos níveis de mercúrio em peixes nos pontos localizados no Rio Cuiabá a jusante do Planalto Guimarães em direção a Porto Jofre, mas essa tendência não se manteve no ponto a jusante de Porto Jofre. 
No estudo de 1998, realizado por HYLANDER e col. (2000a), foi encontrada uma dependência entre concentração de mercúrio em musculatura e distância da fonte. Por essa razão, os autores levantaram a hipótese de que o rio Cuiabá recebe carga de mercúrio em Cuiabá, e esta é transportada para Barão de Melgaço. Esse mercúrio influenciaria os níveis nos peixes de Porto Jofre mais do que em Barão de Melgaço, isto porque haveria a biometilação do mercúrio ao longo do rio, tornando o mercúrio biodisponível nos pontos de coleta mais a jusante como, por exemplo, em Porto Jofre.

De fato, MALM e GUIMARÃES (1996) encontraram na região de Poconé, média de mercúrio em peixes carnívoros de $0,07 \mu \mathrm{g} / \mathrm{g}$, e média geral em todos os outros peixes de $0,06 \mu \mathrm{g} / \mathrm{g}$. Esses valores bem mais baixos na região de Poconé, onde a contaminação por mercúrio advindo da atividade garimpeira tornou a região uma fonte importante de contaminação ambiental por esse metal, podem ser explicados porque a carga de mercúrio recebida pelo rio Cuiabá pode estar sendo transportada e biometilada ao longo do corpo d'água, tornando-se biodisponível nos locais mais distantes à jusante, hipótese levantada por HYLANDER e col. (1994).

De todas as amostras de piranha analisadas, considerando todos os pontos de coleta, $75 \%$ apresentaram valores até $0,21 \mu \mathrm{g} / \mathrm{g}$ e $90 \%$ até $0,39 \mu \mathrm{g} / \mathrm{g}$. Apesar de a coleta de amostras ter sido na época de seca, esses dados estão de acordo com os encontrados por Hylander e col. na campanha de 1992 (HYLANDER e col. 1994), e no estudo realizado em 1998 na época de chuva (HYLANDER e col. 2000a) (ver item 1.9). As diferenças encontradas em relação à época de coleta e a concordância com os dados encontrados no estudo de 1992 (HYLANDER e col. 1994) realizado nos cursos d'água das drenagens, em oposição ao presente estudo que foi feito nas baías da bacia do Alto Paraguai, devem ser melhor investigadas, pois devem estar relacionadas com outros parâmetros, como os físico-químicos, que não são objeto do presente estudo. 
Por outro lado, no estudo realizado pelo grupo de pesquisa da UFMT na Baixada Cuiabana, incluindo Barão de Melgaço, em 1995 (época da seca) e em 1996 (época da chuva), os níveis de mercúrio encontrados em piranhas foram próximos ao do presente estudo e não mostraram diferença estatisticamente significante entre as duas épocas (seca e chuva). A média foi $0,15 \mu \mathrm{g} / \mathrm{g}$, variando de $0,05 \mu \mathrm{g} / \mathrm{g}$ a $0,25 \mu \mathrm{g} / \mathrm{g}$ para época da seca, e $0,20 \mu \mathrm{g} / \mathrm{g}$, variando de $0,05 \mu \mathrm{g} / \mathrm{g}$ a $0,40 \mu \mathrm{g} / \mathrm{g}$ para época da chuva (UFMT 1997).

Comparando-se os diversos estudos realizados na região, nota-se uma semelhança de valores encontrados nos estudos anteriores e dos encontrados no presente estudo (Tabela 9). As diferenças observadas devem ser devidas às diferentes características dos locais de coleta de amostras de peixe, isto é, baías, drenagens e localização em relação ao ponto de recebimento da carga poluidora. 
Tabela 9 - Concentrações de mercúrio $(\mu \mathrm{g} / \mathrm{g})$ em peixes na região do Alto Pantanal referentes a estudos realizados no período de 1991 a 2000, segundo espécie e local de coleta.

\begin{tabular}{|c|c|c|c|c|c|}
\hline Espécie & $\mathbf{n}$ & $\begin{array}{c}\text { Média } \\
(\text { mín-máx })^{\star}\end{array}$ & Local & Ano & Referência \\
\hline $\begin{array}{l}\text { Serrasalmus eigenmanni, } \\
\text { Serrasalmus rhomoeus, } \\
\text { Serrasalmus nattereri } \\
\text { (Piranha) }\end{array}$ & 9 & $(0,04-\overline{--} 0,06)$ & $\begin{array}{l}\text { Rio Bento } \\
\text { Gomes }\end{array}$ & 1991 & LACERDA 1991 \\
\hline $\begin{array}{l}\text { Pseudoplatystoma coruscans } \\
\text { (Pintado) }\end{array}$ & 34 & $\begin{array}{c}0,26 \\
(0,05-0,95)\end{array}$ & $\begin{array}{l}\text { Rios Cuiabá e } \\
\text { Paraguai }\end{array}$ & 1992 & $\begin{array}{l}\text { HYLANDER e } \\
\text { col. } 1994\end{array}$ \\
\hline $\begin{array}{l}\text { Pygocentrus nattereri } \\
\text { (Piranha) }\end{array}$ & 16 & $\begin{array}{c}0,28 \\
(0,09-0,51)\end{array}$ & $\begin{array}{l}\text { Rios Cuiabá e } \\
\text { Paraguai }\end{array}$ & 1992 & $\begin{array}{l}\text { HYLANDER e } \\
\text { col. } 1994\end{array}$ \\
\hline $\begin{array}{l}\text { Pygocentrus nattereri } \\
\text { (Piranha) }\end{array}$ & 15 & $\begin{array}{c}0,15 \\
(0,05-0,25)\end{array}$ & $\begin{array}{c}\text { Baixada } \\
\text { Cuiabana } \\
\text { (incluindo Barão } \\
\text { de Melgaço) }\end{array}$ & $\begin{array}{c}1995 \\
\text { (seca) }\end{array}$ & UFMT 1997 \\
\hline $\begin{array}{l}\text { Pygocentrus nattereri } \\
\text { (Piranha) }\end{array}$ & 12 & $\begin{array}{c}0,20 \\
(0,05-0,40)\end{array}$ & $\begin{array}{c}\text { Baixada } \\
\text { Cuiabana } \\
\text { (incluindo Barão } \\
\text { de Melgaço) }\end{array}$ & $\begin{array}{c}1996 \\
\text { (chuva) }\end{array}$ & UFMT 1997 \\
\hline carnívoros & 67 & $\begin{array}{c}0,07 \\
(0,02-0,21)\end{array}$ & Poconé & 1996 & $\begin{array}{l}\text { MALM e } \\
\text { GUIMARÃES } \\
1996\end{array}$ \\
\hline $\begin{array}{l}\text { Pseudoplatystoma fasciatus } \\
\text { (cachara), } \\
\text { Pseudoplatystoma coruscans, } \\
\text { Serrasalmus spilopleura e } \\
\text { Serrasalmus nattereri } \\
\text { (piranha) }\end{array}$ & 185 & $\begin{array}{c}0,27 \\
(0,04-2,05)\end{array}$ & Alto Pantanal & 1998 & $\begin{array}{l}\text { HYLANDER e } \\
\text { col. } 2000 a\end{array}$ \\
\hline Serrasalmus spp. (piranha) & $\begin{array}{l}54 \\
47\end{array}$ & $\begin{array}{c}-- \\
(0,05-0,5) \\
\text { chuva } \\
-- \\
(0,07-2,05) \\
\text { seca }\end{array}$ & Alto Pantanal & 1998 & $\begin{array}{l}\text { HYLANDER e } \\
\text { col. } 2000 a\end{array}$ \\
\hline Serrasalmus spp. & 44 & $\begin{array}{c}0,16 \\
(0,02-0,50)\end{array}$ & $\begin{array}{c}\text { Rios Cuiabá, } \\
\text { Bento Gomes e } \\
\text { Paraguai } \\
\end{array}$ & 2000 & Presente estudo \\
\hline
\end{tabular}

Em relação somente às espécies de piranhas, nota-se que não houve aumento das concentrações de mercúrio ao longo dos anos. Porém, uma análise mais aprofundada da evolução da contaminação por mercúrio na região do Alto Pantanal ficou comprometida. Por ser essa região muito grande, os estudos realizados não foram feitos nas mesmas áreas específicas, o que seria de fundamental importância pela existência nessa região, de ambientes muito diferentes em termos de dinâmica e características, que influem sobremaneira na incorporação do mercúrio pelos 
organismos aquáticos. Somente esse fato, já limita a comparação entre os dados dos diversos trabalhos. Outra restrição foi o número reduzido de amostras também observado nos outros estudos.

Assim, na análise da evolução da contaminação por mercúrio na região do Alto Pantanal foram considerados somente os dados de piranhas, e também apenas dos estudos feitos nas regiões próximas às áreas estudadas do presente estudo, o que restringiu o número de estudos utilizados na comparação.

Quanto aos níveis de mercúrio encontrados, considerando o limite máximo de tolerância de mercúrio em peixes predadores em vigência no Brasil, estabelecido pela Portaria $\mathrm{n}^{\circ}$ 685/98 do Ministério da Saúde (BRASIL 1998), de 1,0 $\mu \mathrm{g} / \mathrm{g}$ (ppm), nenhum espécime analisado ultrapassou esse limite. Alguns países, entretanto, adotam como limite seguro 0,5 ppm de mercúrio em peixes predadores para consumo humano (LEBEL e col. 1997). No Canadá, Austrália, Israel, Noruega, Suíça e Tailândia o limite é 0,5 ppm de mercúrio em peixes; nos Estados Unidos da América, Alemanha, Dinamarca, Finlândia, Nova Zelândia e Suécia o limite estabelecido é 1,0 ppm. No Japão, o limite é de 0,4 ppm e na Itália 0,7 ppm. A Organização Mundial da Saúde estabelece para peixes predadores o valor de 1,0 ppm. A Food and Drug Administration dos EUA recomenda que para espécies de peixe com níveis próximos de 0,5 ppm o consumo deva ser reduzido para apenas 2 refeições por semana (CFIA 2002; WHO 1991; ATSDR 1999 ; KITAHARA e col. 2000).

Em áreas não contaminadas, os níveis de mercúrio em peixes de diferentes hábitos alimentares são geralmente inferiores a $0,2 \mathrm{ppm}$ para peixes de água doce (GALVÃO e COREY 1987).

Como a população de Barão de Melgaço pode ser considerada como representativa da região estudada, pode-se calcular a ingestão diária de mercúrio, 
apenas via pescado, utilizando os dados do consumo de pescado e da biometria dessa população, obtidos no estudo da UFMT (1997).

Se calcularmos a ingestão diária de mercúrio baseada no consumo de piranha, usando a concentração média encontrada nessa espécie que foi de $0,16 \mu \mathrm{g} / \mathrm{g}$, temos:

Ingestão diária de $\mathrm{Hg}(\mu \mathrm{g})={ }^{1}$ consumo $(\mathrm{g}) /$ dia $\mathrm{X}^{2}$ concentração $\mathrm{Hg}$ no peixe

${ }^{3}$ Peso corporal $(\mathrm{kg})$

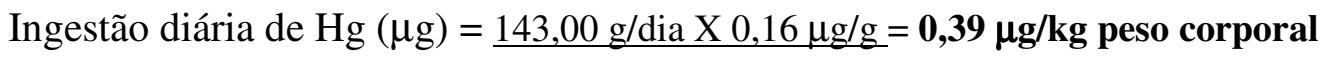
$58,9 \mathrm{KG}$

Onde:

1 consumo médio diário de peixe das mulheres na faixa etária de 15-49 anos, na época da chuva, determinado no estudo da UFMT (1997).

${ }^{2}$ concentração média de $\mathrm{Hg}$ em piranhas no presente estudo.

${ }^{3}$ Peso corporal médio das mulheres na faixa etária de 15-49 anos do estudo da UFMT (1997).

A Organização Mundial da Saúde (OMS) recomenda uma ingestão semanal tolerável de mercúrio de $200 \mu \mathrm{g}(3,30 \mu \mathrm{g} / \mathrm{kg}$ de peso corporal) ou uma ingestão diária ao redor de $30 \mu \mathrm{g}(0,48 \mu \mathrm{g} / \mathrm{kg}$ peso corporal) (WHO 1990).

Segundo a estimativa feita no estudo de Barão de Melgaço (UFMT 1997), a população estudada tem um alto consumo de pescado e este fato determina uma ingestão diária de mercúrio considerada alta se comparada com outras populações, $0,39 \mu \mathrm{g} / \mathrm{kg}$ de peso corporal, valor calculado anteriormente, mas que não ultrapassa a ingestão diária recomendada pela OMS. No entanto, deve-se mencionar que, se fosse calculada a ingestão diária de mercúrio usando as concentrações mais altas encontradas no presente estudo, o consumo de piranha $(0,50 \mu \mathrm{g} \mathrm{de} \mathrm{Hg} / \mathrm{g})$ e de outras espécies que apresentaram concentrações de até $0,72 \mu \mathrm{g} \mathrm{Hg} / \mathrm{g}$ (dourado e barbado), ultrapassariam a ingestão máxima recomendada pela OMS. 


\subsection{Mercúrio nos Sedimentos}

No presente estudo, as concentrações de mercúrio total em sedimento da camada de 0-10 cm variaram de 0,01 a $0,11 \mu \mathrm{g} / \mathrm{g}$, com média de $0,04 \mu \mathrm{g} / \mathrm{g}$ (Tabela 6). Não foram encontradas diferenças estatisticamente significativas entre as áreas estudadas.

HYLANDER e col. (1994, 2000b) também encontraram, nos dois estudos realizados na região do Alto Pantanal, níveis baixos de mercúrio no sedimento. No primeiro estudo, a média de mercúrio no sedimento foi $0,03 \mu \mathrm{g} / \mathrm{g}$ e a concentração variou de 0,01 a 0,04 $\mu \mathrm{g} / \mathrm{g}$. Posteriormente, no estudo feito em 1998 (HYLANDER e col. 2000b), a média de mercúrio total no sedimento foi $0,03 \mu \mathrm{g} / \mathrm{g}$, a mediana foi 0,03 $\mu \mathrm{g} / \mathrm{g}$, o primeiro quartil $0,02 \mu \mathrm{g} / \mathrm{g}$ e o terceiro quartil $0,05 \mu \mathrm{g} / \mathrm{g}$. Nesse último estudo, evidenciou-se uma concentração maior de mercúrio em sedimento da bacia do rio Bento Gomes, que teve média de $0,09 \mu \mathrm{g} / \mathrm{g}$, mediana $0,07 \mu \mathrm{g} / \mathrm{g}$, primeiro quartil 0,05 $\mu \mathrm{g} / \mathrm{g}$ e terceiro quartil $0,12 \mu \mathrm{g} / \mathrm{g}$. Esses níveis mais altos foram atribuídos pelos autores ao fato da região ser área pertencente às de extração de ouro.

Em outro estudo na mesma região, LACERDA e col. (1991) encontraram níveis mais altos de mercúrio na camada superficial de sedimento (primeiros $2 \mathrm{~cm}$ ), 0,06 a 0,08 $\mu \mathrm{g} / \mathrm{g}$, e 0,01 a $0,03 \mu \mathrm{g} / \mathrm{g}$ nas camadas mais profundas (abaixo de $3 \mathrm{~cm}$ ).

No município de Poconé, LACERDA (1991) estudou a distribuição de mercúrio num pequeno córrego que drena os rejeitos produzidos durante 10 anos na atividade de garimpo de ouro. As concentrações de mercúrio em sedimentos variaram de <0,02 ppm a $0,18 \mathrm{ppm}$. As maiores concentrações ocorreram nas proximidades do depósito de rejeitos e foram decaindo à medida que se afastava do mesmo, até atingir valores menores que $0,02 \mathrm{ppm}$.

Em sedimentos lacustres superficiais de regiões temperadas, a concentração média de mercúrio é de 0,33 ppm (ANDREN e NRIAGU 1979), onde os corpos d'água estão sujeitos à contribuição atmosférica de mercúrio de origem antropogênica (NRIAGU 
1979). Entretanto, os valores de "background" encontrados em áreas temperadas são em média de 0,01 ppm (LACERDA 1991). É difícil a comparação com regiões temperadas, caracterizadas por um forte desenvolvimento industrial e freqüentemente com presença natural de minérios de mercúrio.

As concentrações encontradas no presente trabalho mostraram-se inferiores às outras áreas de garimpo de ouro no Brasil. Por exemplo, no rio Madeira (AM), os níveis de mercúrio em sedimentos variaram de 0,05 a 0,28 ppm (LACERDA e col. 1987 citados por LACERDA 1991), no rio Mutum (AM) de 0,21 a 19,8 ppm, e no rio Paraíba do Sul (RJ) de 0,30 a 0,90 ppm (PFEIFFER e col. 1989 citados por LACERDA 1991).

Em rios não contaminados da Amazônia, os níveis são inferiores a 0,02 ppm (LACERDA 1991) e em rios não contaminados em outros locais no mundo são inferiores a 0,30 ppm (SALOMONS e FORSTNER 1984).

GUIMARÃES e col. (1999) determinaram as concentrações de mercúrio em amostras de sedimento no rio Bento Gomes em 1995 na época de seca. Nas camadas superficiais, os níveis foram mais altos $(0,13-0,26 \mu \mathrm{g} / \mathrm{g})$ em Poconé e em locais a jusante, e nas camadas mais profundas variaram de $0,02-0,08 \mu \mathrm{g} / \mathrm{g}$, sugerindo, segundo os autores, alguma mobilização do mercúrio a partir das áreas de mineração de ouro.

Os níveis de mercúrio no sedimento no presente estudo não diferem dos encontrados nesses estudos, realizados na mesma região.

Na bacia Amazônica, há muitos estudos que mostram que as concentrações de mercúrio no sedimento dependem de vários outros parâmetros ambientais (por exemplo, presença de alumínio, ferro e manganês); porém, no Pantanal não está bem esclarecido o papel desses parâmetros na contaminação por mercúrio no sedimento, já que estudos feitos (HYLANDER e col. 2000b) indicam que o ciclo do mercúrio no 
Pantanal deve ser governado por outros parâmetros diferentes dos que o regem na bacia Amazônica, onde os solos são mais jovens e de origem diferente. 


\subsection{Mercúrio em Material Particulado em Suspensão}

A média das concentrações de mercúrio no material particulado em todas as áreas estudadas foi $0,06 \mu \mathrm{g} / \mathrm{g}$, variando de 0,02 a $0,18 \mu \mathrm{g} / \mathrm{g}$.

Atividades antropogênicas que causam erosão do solo, como construção de rodovias, pecuária, agricultura, aumentam a quantidade de material particulado na água, que influencia o conteúdo de mercúrio, independentemente de atividades de mineração de ouro a montante (RICHARD e col. 2000). O mercúrio é adsorvido ao material particulado, sendo por ele transportado para os rios e transformado em metilmercúrio biodisponível, principalmente em águas ricas em matéria orgânica dissolvida mas pobre em matéria inorgânica dissolvida.

LACERDA (1991), em estudo feito em Poconé (MT) em áreas de rejeito de mineração de ouro, observou um aumento muito grande na concentração de mercúrio em material particulado em suspensão durante o período de chuva. As concentrações de mercúrio no material particulado em suspensão subiram de $<0,02$ ppm para 0,61 ppm. Esses resultados mostram a capacidade das chuvas de lixiviar sedimentos argilosos enriquecidos de mercúrio, sugerindo que a erosão seguida do transporte de mercúrio associado a partículas finas é o principal mecanismo para a contaminação do sistema de drenagem. Assim, as concentrações de mercúrio no material particulado estão mais relacionadas às concentrações de mercúrio nos peixes do que o mercúrio no sedimento. No estudo feito por HYLANDER e col.(2000a) na região do Alto Pantanal, os autores sugerem que os níveis mais altos de mercúrio em peixes capturados na região de Barão de Melgaço podem ser devidos a maior quantidade de material particulado em suspensão do rio Cuiabá em comparação ao rio Paraguai, causada pela agricultura, dragas e desmatamento das margens do rio. O mercúrio é então adsorvido a esse material e pode ser liberado para a água e ser transformado em metilmercúrio biodisponível, especialmente em águas ricas em matéria orgânica dissolvida, porém pobre em matéria inorgânica dissolvida. 
Em estudo realizado no rio Cuiabá (UFMT 1997), no trecho entre Santo Antônio do Leverger e Barão de Melgaço, a concentração média de mercúrio no material particulado em suspensão foi de $0,03 \mu \mathrm{g} / \mathrm{g}$, variando de 0,007 a $0,07 \mu \mathrm{g} / \mathrm{g}$ na estação da seca. $\mathrm{Na}$ estação de chuva, a média foi de $0,05 \mu \mathrm{g} / \mathrm{g}$, variando de 0,03 a $0,08 \mu \mathrm{g} / \mathrm{g}$.

Nessa região, a análise do material particulado em suspensão é também importante porque, além das populações usarem o rio para a pesca, usam suas águas também para beber, cozinhar, tomar banho, irrigar plantações, etc, constituindo assim uma importante fonte de contaminação (UFMT 1997).

No presente estudo, os níveis de mercúrio no material particulado em suspensão no rio Cuiabá apresentaram média de $0,06 \mu \mathrm{g} / \mathrm{g}$ e variação de 0,02 a $0,14 \mu \mathrm{g} / \mathrm{g}$, no rio Bento Gomes a média foi de $0,03 \mu \mathrm{g} / \mathrm{g}$ com variação de 0,02 a $0,04 \mu \mathrm{g} / \mathrm{g}$ e no rio Paraguai a média foi de $0,08 \mu \mathrm{g} / \mathrm{g}$ variando de 0,02 a $0,18 \mu \mathrm{g} / \mathrm{g}$. Devido ao número reduzido de amostras no rio Paraguai, sendo que uma delas apresentou nível muito alto $(0,18 \mu \mathrm{g} / \mathrm{g})$, uma análise mais aprofundada da distribuição das concentrações de mercúrio nas diversas áreas fica prejudicada.

Se compararmos as concentrações de mercúrio em material particulado em suspensão das amostras do rio Cuiabá do estudo anterior (UFMT 1997) com as concentrações determinadas no rio Cuiabá no presente estudo, estas últimas são superiores. A explicação pode ser a influência dos municípios de Cuiabá e Várzea Grande, com a contribuição do aporte de material particulado nessa drenagem, devido ao crescimento da região nos últimos anos. 


\subsection{Correlações entre Mercúrio em Peixes, Sedimentos e Material Particulado em Suspensão}

O sedimento sempre foi considerado o principal local onde ocorre a produção de metilmercúrio, nos ecossistemas aquáticos. Entretanto, em áreas tropicais alagadas, a vegetação aquática flutuante e as florestas inundadas ocupam áreas extensas e podem ser importantes sítios de metilação do mercúrio (GUIMARÃES e col. 2000).

GUIMARÃES e col. (2000) estudaram, experimentalmente, a capacidade de metilação de mercúrio nos sedimentos e raízes de macrófitas de baías das bacias dos rios Cuiabá e Paraguai na região do Alto Pantanal e em outras regiões. Em todas as regiões, a metilação em macrófitas foi de $13,7 \%$, enquanto que em sedimentos foi de apenas $0,6 \%$. Segundo os autores, as taxas entre os potenciais de metilação nesses dois tipos de amostras são o melhor parâmetro de comparação entre os diferentes locais ou estudos. Encontraram que, em média, o potencial de metilação nas partes submersas das macrófitas estudadas é 27,5 vezes maior do que nos sedimentos. Em estudo realizado nos lagos do Pantanal, em 1998, a metilação em raízes de Eichlornia azurea foi, em média, 58,8 vezes maior do que nos sedimentos. Nesse mesmo estudo, o maior potencial de metilação (34\%) foi observado em E. azurea das águas ácidas da Baía Siá Mariana. Nas outras baías do Pantanal, a metilação nessas espécies variou de 1,8 a 25\%. Nesse estudo, houve indicação de que a metilação do mercúrio em macrófitas varia com as espécies, mas também é fortemente influenciada pelos fatores específicos locais. Os estudos no Brasil, que mediram, simultaneamente, os potenciais de metilação e concentrações de metilmercúrio, encontraram concentrações de metilmercúrio mais altas na coluna d'água dos locais de maior potencial de metilação de mercúrio (GUIMARÃES e col. 2000).

Alguns autores sugerem que as condições levemente anóxicas nas formações densas de macrófitas favorecem a metilação do mercúrio, e que os exudatos das raízes são uma fonte de carbono que simula a atividade bacteriana. A metilação em raízes de Eichhornia crassipes é fortemente influenciada pela temperatura, com um máximo a $35^{\circ} \mathrm{C}$ e uma forte inibição acima de $50^{\circ} \mathrm{C}$, sendo mais alta em pH 6-7 do que acima 
ou abaixo dessa faixa, e também estimulada pela baixa condutividade (MAURO e col. 1999).

Experimentos com estimulação e inibição da atividade de sulfato-redução sugeriram que as bactérias sulfidogênias são as principais bactérias responsáveis pela metilação nas raízes de macrófitas e também no sedimento (GUIMARÃES e col. 1998; MAURO e col.1999).

Um alto potencial de metilação do mercúrio em macrófitas aquáticas é relevante por diversas razões. Esta característica da vegetação aquática tropical estimula a produção de metilmercúrio altamente biodisponível, em parte por causa de sua alta densidade, $1 \mathrm{~kg}$ de peso $\mathrm{seco} / \mathrm{m}^{2}$, e uma grande área relativa em contato direto com a coluna d'água (GUIMARÃES e col. 2000), além de que isto constitui a maior fonte de absorção de metilmercúrio nas cadeias alimentares aquáticas tropicais, porque a zona da raiz dessas plantas aquáticas é densamente povoada por uma variedade de invertebrados e peixes e representa uma fonte essencial de carbono para as cadeias alimentares aquáticas. Contrastando, a produção de metilmercúrio nos sedimentos é aproximadamente 30 vezes menor do que em raízes das macrófitas e sua biodisponibilidade é provavelmente limitada, como também o fluxo sedimento água de metilmercúrio.

Foi encontrada correlação entre os níveis de mercúrio nos sedimentos da camada de 0-10 cm das áreas estudadas e nas piranhas, porém a correlação foi negativa. Este fato pode ser devido à não biodisponibilidade do mercúrio presente nos sedimentos, pois esses atuam como pontos de acumulação de mercúrio, não significando que o mercúrio nele presente se encontre na forma biodisponível. Já, a correlação entre concentração de mercúrio da camada de sedimento de 0-2 $\mathrm{cm}$ e mercúrio em piranha foi positiva. Esse fato pode ser atribuído aos processos de transporte e deposição de sedimentos fluviais, que sobrepõem camadas sucessivas com diferentes níveis de contaminação em função das fontes de poluição. Assim, a análise do sedimento de 0$10 \mathrm{~cm}$ inclui as camadas mais profundas com diferentes gradientes de contaminação porque no momento da coleta da amostra há a mistura das várias camadas. 
Provavelmente, o sedimento da camada mais superficial é o que sofre trocas de metilmercúrio com a coluna d'água, sedimentação do mercúrio presente no material particulado em suspensão, o que poderia explicar a correlação positiva de mercúrio em piranha e mercúrio na camada de 0-2 cm.

Seria interessante verificar a existência de correlação entre mercúrio em material particulado em suspensão e mercúrio no sedimento $0-2 \mathrm{~cm}$, mas em razão de se ter dados disponíveis desses dois parâmetros somente para três das áreas estudadas, não foi possível fazer a análise de tal correlação.

Já os dados de mercúrio em material particulado em suspensão e mercúrio em sedimento da camada de 0-10 cm, estavam disponíveis para cinco das áreas estudadas, então procedeu-se à análise de correlação nessas cinco áreas. Não foi encontrada correlação entre as concentrações de mercúrio no sedimento de profundidade de $0-10 \mathrm{~cm}$ e as concentrações de mercúrio em material particulado em suspensão, e nem entre mercúrio no sedimento $(0-10 \mathrm{~cm})$ e quantidade de matéria orgânica no sedimento.

Alguns autores também não encontraram correlação entre mercúrio em sedimento e mercúrio em peixes. Em um estudo feito em lagos do Canadá, as concentrações de mercúrio em peixes variaram de 0,003 a $0,88 \mu \mathrm{g} / \mathrm{g}(\mathrm{ppm})$, e a concentração mais alta foi encontrada em lagos menos contaminados (HARRISON e KLAVERKAMP 1990).

Verifica-se no presente estudo que o sedimento da camada mais superficial $(0-2 \mathrm{~cm})$, que é responsável pela exposição direta à biota, pode ter condicionado a concentração de mercúrio nas populações de piranhas estudadas. Nas amostras que foram coletadas envolvendo camadas mais espessas $(0-10 \mathrm{~cm})$, não se verificou a correlação com a contaminação das populações de piranha, o que indica que o sedimento superficial é o que melhor reflete a contaminação da biota, da mesma forma, o material particulado em suspensão, que afeta diretamente a comunidade íctica, também apresentou correlação positiva com a contaminação das piranhas. 
A análise de correlação entre concentrações de mercúrio em piranhas e em material particulado mostrou-se significativa. Este fato está de acordo com outros estudos em que também foi encontrada tal correlação. A piranha tem por hábito permanecer na coluna d'água, em ambientes lênticos, o que pode explicar a correlação positiva entre mercúrio em piranha e mercúrio em material particulado em suspensão. 


\section{CONCLUSÕES}

- As concentrações de mercúrio total nos 74 peixes predadores analisados variaram de 0,02 a $0,80 \mu \mathrm{g} / \mathrm{g}(\mathrm{ppm})$ com média de $0,19 \pm 0,18 \mu \mathrm{g} / \mathrm{g}$. Nenhum espécime analisado apresentou concentração de mercúrio acima de 1,00 $\mu \mathrm{g} / \mathrm{g}$, estabelecido pela legislação brasileira como valor máximo permitido em peixes predadores para consumo humano. Porém, considerando que na região estudada a população tem alto consumo de pescado e que algumas espécies apresentaram concentrações mais elevadas, como o barbado e dourado, os peixes carnívoros da região devem ser monitorados, já que estudos indicam que níveis abaixo de $1,00 \mu \mathrm{g} / \mathrm{g}$ já podem causar alterações importantes na saúde, dependendo da quantidade de pescado consumido.

- As concentrações de mercúrio em piranhas (Serrasalmus spp.) variaram de 0,02 a $0,50 \mu \mathrm{g} / \mathrm{g}$, com média de 0,16 $\pm 0,12 \mu \mathrm{g} / \mathrm{g}$. Usando esse valor para o cálculo de ingestão diária de mercúrio para mulheres entre 15-49 anos da região estudada, obteve-se o valor de $0,39 \mu \mathrm{g} / \mathrm{kg}$ de peso corporal, valor este abaixo do recomendado pela OMS de $0,48 \mu \mathrm{g} / \mathrm{kg}$ de peso corporal.

- Apesar de os níveis de mercúrio em pescado não terem ultrapassado os limites recomendados para consumo humano, observa-se uma contaminação do ambiente. Porém, os resultados, quando comparados com estudos feitos na mesma região, não indicam um aumento na evolução da contaminação do pescado.

- Foi encontrada correlação entre as concentrações de mercúrio em piranha e concentrações de mercúrio em material particulado em suspensão.

- As áreas que apresentaram concentrações mais elevadas de mercúrio em piranha foram CBA 2 e PAG 4. 
- As médias das concentrações de mercúrio em sedimento da camada de 0-10 cm variaram de 0,01 a $0,11 \mu \mathrm{g} / \mathrm{g}$ nas áreas estudadas, a média foi de $0,04 \pm 0,03 \mu \mathrm{g} / \mathrm{g}$. Não houve diferença estatisticamente significativa entre as concentrações de mercúrio em sedimento das diversas áreas. Os níveis de mercúrio no sedimento foram inferiores aos de outras áreas de garimpo de ouro no Brasil. Os resultados encontrados não permitem uma conclusão sobre o estado de contaminação da área estudada em relação ao sedimento.

- Não foi encontrada correlação entre as concentrações de mercúrio e de matéria orgânica no sedimento da camada de 0-10 cm.

- Não foi encontrada correlação entre concentração de mercúrio em sedimento da camada de 0-10 cm e em material particulado em suspensão.

- Não foi encontrada correlação positiva entre mercúrio em piranhas e mercúrio no sedimento da camada de $0-10 \mathrm{~cm}$, mas houve correlação positiva entre mercúrio em piranhas e mercúrio em sedimento da camada de 0-2 cm.

- A média das concentrações de mercúrio em sedimento da camada de 0-2 cm em todas as áreas estudadas foi de $0,05 \mu \mathrm{g} / \mathrm{g}$, variando de $0,02 \mu \mathrm{g} / \mathrm{g}$ a 0,07 $\mu \mathrm{g} / \mathrm{g}$. Não houve diferença estatisticamente significativa entre as concentrações de mercúrio em sedimento 0-2 cm das diversas áreas.

- A média das concentrações de mercúrio em material particulado em suspensão em todas as áreas estudadas foi de $0,06 \mu \mathrm{g} / \mathrm{g}$, variando de 0,02 a $0,18 \mu \mathrm{g} / \mathrm{g}$. Não foi encontrada diferença estatisticamente significativa entre as concentrações de mercúrio no material particulado das áreas estudadas. As concentrações de mercúrio no material particulado do rio Cuiabá foram superiores às concentrações encontradas em estudo anterior na mesma região. Este fato pode ser devido a maior quantidade de carga poluente liberada no 
rio na área de influência dos municípios de Cuiabá e Várzea Grande, conseqüência do próprio crescimento dessas cidades.

- Apesar de os dados aqui analisados serem parciais, estes já apontam para algumas questões que devem ser investigadas posteriormente com dados completos do projeto GEF. Os resultados em peixes indicam a necessidade de um monitoramento da região do Pantanal, e os de material particulado em suspensão também indicam uma tendência temporal de transporte de mercúrio para as áreas à jusante da Baixada Cuiabana. Há a necessidade de se quantificar melhor esse transporte e investigar a procedência do contaminante.

- A atividade garimpeira na Baixada Cuiabana diminuiu o lançamento de mercúrio nas drenagens nos últimos anos, porém outras fontes como lançamento de esgoto urbano e atividades que propiciam a erosão, têm que ser controladas. Outros estudos já apontaram a importância do transporte do mercúrio pelo material particulado em suspensão. Assim, a médio e longo prazos, o aporte do mercúrio, que atualmente não atinge quantidades muito altas, pode representar uma importante fonte de contaminação na região do Pantanal. 


\section{REFERÊNCIAS BIBLIOGRÁFICAS}

Ahmad S, Qureshi IH. Fast mercury removal from industrial effluent. J Radioanal Nuclear Chem 1989; 130(2): 347-352.

Allard B, Arsenie I. Abiotic reduction of mercury by humic substances in aquatic system-an important process for the mercury cycle. Water Air Soil Poll 1991; 56: 457-464.

Andren AW, Nriagu JO. The global cycle of mercury. In: Nriagu JO. Ed. The biogeochemistry of mercury in the environment. Amsterdam: Elsvier/North Holland Biomedical Press; 1979. p. 1-21.

[ATSDR]. Agency for Toxic Substances and Disease Registry. Toxicological Profile for Mercury. Atlanta. GA: U.S. Department of Health and Human Services, Public Health Service. 1999.

Bakir F, Damluji SF, Amin-Zaki L, Murtadha M, Khalidi A, Al-Rawi NY et al. Methylmercury poisoning in Iraq. Science 1973; 181: 230-241.

Barbosa AC, Boischio AA, East GA et al. Mercury contamination in the Brazilian Amazon. Environmental and Occupational Aspects. Water Air Soil Poll 1995; 80: 109-121.

Bellato V. Quadro demonstrativo da atividade garimpeira e sua influência na ocupação do município de Poconé - Estado de Mato Grosso. Cuiabá - MT; 2000 [Monografia apresentada à Fundação Universidade Federal de Mato Grosso Instituto de Ciências Exatas e da Terra - Departamento de Geologia Geral, para obtenção do Título de Especialista na área de Meio Físico em Estudos de Impacto Ambiental]. 
Berlin M. The toxicokinetics of mercury. In: Schmidt EHF e Hildebrandt AG eds. Symposium on Health Evaluation of Heavy Metals in Infant Formula and Junior Food. Berlim (West), 1981. Proceedings. Berlin, Springer-Verlag, 1983. p. 147-60.

Berlin M. Mercury. In: Friberg L, Nordberg GF, Nordman C (eds): Handbook on the Toxicology of Metals. 2d ed. Specific Metals. Amsterdam: Elsevier, 1986, v2, p.386-445.

Berlin M, Fazackerly J, Nordberg G. The uptake of mercury in the brains of mammals exposed to mercury vapor and mercuric salts. Arch Environ Health 1969; 18: 719-729.

Bjornberg AA, Hakanson L, Lundberg K. A theory on the mechanisms regulating the bioavailability of mercury in natural water. Environ Pollut 1988; 49: 53-61.

Blume HP, Brummer G. Prediction of heavy metal behavior in soil by means of simple field tests. Ecotox Environ Safe 1991; 22: 164-174.

Boischio AAP. Human Ecology of the Riverine People (Caboclos or Ribeirinhos) Along the Upper Madeira River with focus on Mercury Pollution Through Fish Consumption. Indiana; 1996 [PhD thesis-School of Public and Environmental Affairs. Indiana University].

Boischio AA, Henshel DS. Risk assessment of mercury exposure through fish consumption by the riverside people in the Madeira Basin, Amazon, 1991. Neurotoxicology 1996; 17 (1): 169-176.

Brasil. Portaria $n^{\circ}$ 685, de 27 de agosto de 1998. Ministério da Saúde. Republicada no Diário Oficial da República Federativa do Brasil, Brasília, 24, set 1998. 
[CFIA]. Canadian Food Inspection Agency. Fact Sheet: Food safety facts on mercury and fish consumption. [on line] 2002. Disponível em <URL:http://www.inspection.gc.ca/english/corpaffr/foodfacts/mercurye.shtml\#top > [Janeiro 2003].

Cope WG, Wiener JG, Rada RG. Mercury accumulation in yellow perch in Wisconsin seepage lakes: Relation to lake characteristics. Environ Toxicol Chem 1990; 9 (7): 931-940.

Cox C, Clarkson TW, Marsh DO, Amin-Zaki L, Tikriti S, Myers GG. Dose-response analysis of infants prenatally exposed to methylmercury. An application of a single compartment model to single-strand hair analysis. Environ Res 1989; 49: 318-332.

Davidson PW, Myers GJ, Cox C, Axtell C, Sloanereeves J, Cernichiari E et al. Effects of prenatal and postnatal methylmercury exposure from fish consumption on neurodevelopment: Outcomes at 66 months of age in the Seychelles Child Development Study. JAMA 1998; 280 (8): 701-707.

[DNPM]. Departamento Nacional de Produção Mineral. Sumário Mineral 1999, 2002 [on line]. Brasília. Disponível em<URL:http://www.dnpm.gov.br> [2003 fev 3]

Dolbec J, Mergler D, Passos CJP, Moraes SLS. Methylmercury exposure affects motor performance in riverine population of the Tapajós river, Brazilian Amazon. Int Arch Occ Env Hea 2000; 73 (3): 195-203.

Farid LH. Diagnóstico preliminar dos impactos ambientais gerados por garimpos de ouro em Alta Floresta (MT): estudo de caso. Rio de Janeiro: CETEM/CNPq; 1992. Tecnologia Mineral 2.

Galvão LAC, Corey G. Mercúrio. Serie Vigilância 7. Centro Panamericano de Ecologia Humana y Salud, Organización Panamericana de Salud, Organización Mundial de la Salud. Metepec, México. 1987. 
Glass GE, Sorensen JA, Schmidt K, Rapp G, Yap D, Fraser D. Mercury deposition and sources for the Upper Great Lakes Region. Water Air Soil Poll 1991; 56: 235249.

Gonçalves GO; Paiva EC. Otimização da metodologia para determinação de mercúrio total em rochas, solos e sedimentos. Rio de Janeiro, Centro de Tecnologia Mineral (CETEM). Departamento de Análises Químicas e de Meio Ambiente (DQI). RI 0013/1995.

Goyer RA. Toxic Effects of Metals. In: Klaassen CD (ed), Amdur MO, Doull J (eds. emeriti) Casarett \& Doull's Toxicology - The Basic Science of Poisons. $5^{\text {th }}$ ed. International Ed. New York: McGraw-Hill, 1996, p.691-736.

Grandjean P, Weihe P, White RF, Debes F. Cognitive performance of children prenatally exposed to "safe" levels of methylmercury. Environ Res 1998; 77: 16572.

Grandjean P, White RF, Nielsen A, Cleary D, Santos ECO. Methylmercury neurotoxicology in Amazon children downstream from gold mining. Environ Health Persp 1999; 107: 586-591.

Guimarães JRD, Meili M, Malm O, Brito EMS. Hg methylation in sediments and floating meadows of a tropical lake of the Pantanal wetland, Brazil. Sci Total Environ 1998; 213: 165-175.

Guimarães JRD, Malm O, Meili M. Mercury in Soils, Sediments and Fish Around the Poconé Gold Mining Area, Pantanal, Brazil: Some Mobilisation But No Health Risks. In: Book of Abstracts of Mercury as a Global Pollutant $-5^{\text {th }}$ International Conference. 1999, May 23-28, Rio de Janeiro (BR). Rio de Janeiro, CETEM; 1999. p.154. 
Guimarães JRD, Meili M, Hylander LD, Silva EC, Roulet M, Mauro JBN et al. Mercury net methylation in five tropical flood plain regions of Brazil: high in the root zone of floating macrophyte mats but low in surface sediments and flooded soils. Sci Total Environ 2000; 261: 99-107.

Hacon S, Rochedo ERR, Campos RRR, Lacerda LD. Mercury exposure through fish consumption in the urban area of Alta Floresta in the Amazon Basin. J Geochem Explor 1997; 58: 209-216.

Hall BD, Bodaly RA, Fudge RJP, Rudd JWM, Rosenberg DM. Food as the dominant pathway of methylmercury uptake by fish. Water Air Soil Poll 1997; 100(1-2): 1324.

Hamilton SK, Sippel SJ, Melack JM. Inundation patterns in the Pantanal wetland of South America determined from passive microwave remote sensing. Arch Hydrobiol 1996; 137: 1-23.

Harada M. Minamata disease: Methylmercury poisoning in Japan caused by environmental pollution. Crit Rev Toxicol 1995; 25: 1-24.

Harrison SE, Klaverkamp JF. Metal contamination in liver and muscle of northern pike (Esox lucius) and white sucker (Catostomus commersoni) and in sediments from lakes near the smelter at Flin Flon, Manitoba. Environ Toxicol Chem 1990; 9: 941956.

Hurley JP, Watras CJ, Bloom NS. Mercury cycling in a northern Wisconsin seepage lake: The role of particulate matter in vertical transport. Water Air Soil Poll 1991; 56: 543-551.

Hutton M. Human Health concerns of lead, mercury, cadmium and arsenic. In: Hutchinson TC e Meema KM, eds. Lead, mercury, cadmium and arsenic in the environment. Chichester, John Wiley \& Sons, 1987. p. 53-68. 
Hylander LD, Silva EC, Oliveira LJ, Silva SA, Kuntze EK; Silva DX. Mercury levels in Alto Pantanal: A screening study. Ambio 1994; 23 (8): 478-484.

Hylander LD, Pinto FN, Guimarães JRD, Meili M, Oliveira JO, Silva EC. Fish mercury concentration in the Alto Pantanal, Brazil: influence of season and water parameters. Sci Total Environ 2000a; 261: 9-20.

Hylander LD, Meili M, Oliveira LJ, Silva EC, Guimarães JRD, Araujo DM et al. Relationship of mercury with aluminum, iron, and manganese oxy-hydroxides in sediments from the Alto Pantanal, Brazil. Sci Total Environ 2000b; 260: 97-107.

Kazantzis G. Mercury. In: Waldron HA, ed. Metals in the Environment. London, Academic Press, 1980. p. 221-61.

Kitahara SE, Okada IA, Sakuma AM, Zenebon O, Jesus RS, Tenuta-Filho A. Mercúrio total em pescado de água-doce. Ciênc Tecnol Aliment 2000; 20(2): 267273.

Lacerda LD. Dispersão de mercúrio em uma drenagem afetada por rejeitos de atividade garimpeira em Poconé, Mato Grosso. In: : Veiga MM, Fernández FRC, organizadores. Poconé: Um campo de estudos do impacto ambiental do garimpo. Rio de Janeiro: CETEM/CNPq. 1991. 113p. (Série Tecnologia Ambiental 1).

Lacerda LD, Salomons W, Pfeiffer WC. Mercury distribution in sediments profiles from lakes of the high Pantanal, Mato Grosso State, Brazil. Biogeochemistry 1991; 14: 91-97.

Lebel J, Mergler D, Lucotte M, Amorim M, Dolbec J, Miranda D, Arantes G, Rheault I, Pichet P. Evidence of nervous system dysfunction in Amazonian popuations exposed to low-levels of methylmercury. Neurotoxicology 1995; 16(4): $1-11$. 
Lebel J, Mergler D, Lucotte M, Amorim M, Dolbec J, Miranda D et al. Evidence of early nervous systm dysfunction in Amazonian populations exposed to low-levels of methylmercury. Neurotoxicology 1996; 17(1): 157-68.

Lebel J, Roulet M, Mergler D, Lucotte M, Larribe F. Fish diet and mercury exposure in a riparian Amazonian population. Water Air Soil Poll 1997; 97: 31-44.

Lebel J, Mergler D, Branches F, Lucotte M, Amorim M, Larribe F, Dolbec J. Neurotoxic effects of low-level mehylmercury contaminaton in the Amazonian basin. Environ Res 1998; 79: 20-32.

Lindberg SE, Turner RR, Meyers TP, Taylor GE Jr, Schroeder WH. Atmospheric concentrations and deposition of $\mathrm{Hg}$ to a deciduous forest at Walker Branch Watershed, Tennessee, USA. Water Air Soil Poll 1991; 56: 577-594.

Lodenius M, Autio S. Effects of acidification on the mobilization of cadmium and mercury from soils. Arch Environ Con Tox 1989; 18: 261-267.

Mahaffey KR. Recent advances in recognition of low -level methylmercury poisoning. Curr Opin Neurol 2000; 13: 699-707.

Malm O, Castro MB, Branches FJP, Zuffo CE, Padovani C, Viana JP et al. Fish and human hair as biomotors of mercury contamination on Tapajós, Madeira and Negro River basins, Amazon, Brazil. Scope Meeting. In: Proceedings of the International Workshop on "Environmental Mercury Pollution and Health Effects in Amazon River Basin. 1994. p. 25-32.

Malm O; Guimarães JRD. Avaliação da contaminação dos peixes nos corpos hídricos próximos à cidade de Poconé - MT. In: OPAS. Projeto de Avaliação de riscos à saúde na região amazônica relacionados com a contaminação ambiental por mercúrio. Relatório final (Projeto OPAS/ECO-GTZ). Brasília/DF, março de 1996. 
Marins RV, Imbassahy JA, Pfeiffer WC, Bastos WR. Estudo preliminar da contaminação atmosférica por mercúrio em área produtora de ouro na cidade de Poconé - Mato Grosso - MT. In: : Veiga MM, Fernández FRC, organizadores. Poconé: Um campo de estudos do impacto ambiental do garimpo. Rio de Janeiro: CETEM/CNPq. 1991. 113p. (Série Tecnologia Ambiental 1).

Mattos JP. Indústria do turismo como fonte de renda (Município de Barão de Melgaço - MT). Cuiabá; 1997. [Tese de Bacharelado - Universidade Federal de Mato Grosso, Departamento de Ciências Contábeis].

Mauro JBN, Guimarães JRD, Melamed R. Mercury methylation in a tropical macrophyte: influence of abiotic parameters. Appl Organomet Chem 1999; 13: 1-6.

Miranda JG, Cipriani M, Mártires RAC, Giaconi WJ. Atividades Garimpeiras no Brasil: Aspectos Técnicos, Econômicos e Sociais. Rio de Janeiro: CETEM/CNPq, 1997. (Série Estudos e Documentos, 38).

Mitra S. Mercury in the ecosystem: its dispersion and pollution today. Aedermannsdorf, Trans Tech Publications, 1986.

[MMA]. Ministério do Meio Ambiente, dos Recursos Hídricos e da Amazônia Legal. Plano de Conservação da Bacia do Alto Paraguai - PCBAP. Vol. II, Tomo III Diagnóstico dos Meios Físico e Biótico. 1997

Nater EA, Grigal DF. Regional trends in mercury distribution across the Great Lakes States, north central U.S.A. Nature 1992; 358: 139-141.

Nriagu JO. The biogeochemistry of mercury in the environment. Amsterdan: Elsevier, North Holland Biochemical Press; 1979.

[OAS]. Organization of American States. Implementation of Integrated Watershed Management Practices for the Pantanal and Upper Paraguay River Basin Project 
Description. USDE - Unit for Sustainable Development and Environment.[on line] 2002. Disponível em www.oas.org/usde/ALTOPARA/Pd.htm[2003 jan 20]

Palheta D, Taylor A. Mercury in environmental and biological samples from a gold mining área in the Amazon region of Brazil. Sci Total Environ 1995; 168(1): 63-9.

Oliveira EF, Silva EC, Ozaki SK, Ferreira MS, Yokoo EM. Mercúrio via cadeia trófica na Baixada Cuiabana: ensaios preliminares. In: Seminário Nacional Riscos e Conseqüências do uso do mercúrio; 1989. Brasília. FINEP, Ministério da Saúde, IBAMA, CNPq. Rio de Janeiro;1990. p.202-210.

Phillips DJH e Rainbow PS. Biomonitoring of trace aquatic contaminants. London, Chapman \& Hall, 1994.

Richard S, Arnoux A, Cerdan P, Reynouard C, Horeau V. Mercury levels of soils, sediments and fish in French Guiana, South America. Water Air Soil Poll 2000; 124: $221-244$.

Roulet M, Lucotte M, Canuel R, Farella N, Courcelles M, Guimarães JRD et al. Increase in mercury contamination recorded in lacustrine sediments following deforestation in the Central Amazon. Chem Geol 2000; 165: 243-266.

Salomão EP. O ofício e a condição de garimpar. In: Rocha, GA, ed. Em busca do ouro: garimpos e garimpeiros no Brasil. Rio de Janeiro: Marco Zero, 1984. p.3586.

Salomons W, Forstner U. Metals in the hydrocycle. Berlin: Springer Verlag; 1984.

Santos ECO, Jesus IM, Brabo ES, Loureiro ECB, Mascarenhas AFS, Weirich J et al. Mercury exposures in riverside Amazon Communities in Pará, Brazil. Environ Res 2000; 84: 100-107. 
Sazima I, Machado FA. Underwater observations of piranhas in western Brazil. Environ Biol Fish 1990, 28: 17-31.

Schuster E. The behavior of mercury in the soil with special emphasis on complexation and adsorption processes - a review of the literature. Water Air Soil Poll 1991; 56: 667-680.

[SEMA]. Secretaria Especial do Meio Ambiente. Avaliação e controle ambiental em áreas de extração de ouro no Estado de Mato Grosso $2^{\circ}$ Relatório. Coordenadoria do Meio Ambiente da Secretaria do Trabalho e Desenvolvimento Social do Mato Grosso. Junho de 1987. 178p. Anexos com mapas e documento fotográfico.

Silva AP, Silva EC. Estudos biogeoquímicos sobre o mercúrio em ambientes aquáticos de Poconé. In: Veiga MM, Fernández FRC, organizadores. Poconé: Um campo de estudos do impacto ambiental do garimpo. Rio de Janeiro: CETEM/CNPq. 1991. 113p. (Série Tecnologia Ambiental 1).

UFMT. Universidade Federal do Mato Grosso. Departamento de Química - Instituto de Ciências Exatas e da Terra. Risco de contaminação por mercúrio via cadeia trófica na baixada Cuiabana - Brasil. Relatório final. 1997.

UFMT. Universidade Federal do Mato Grossso. Departamento de Química Instituto de Ciências Exatas e da Terra. Resultados analíticos da primeira campanha de amostragem. Subprojeto 1.4 - Distribuição e Transporte de Mercúrio na Bacia do Paraguai. Projeto Implementação de Práticas de Gerenciamento Integrado da Bacia Hidrográfica para o Pantanal e Bacia do Alto Paraguai. ANA/GEF/PNUMA/OEA. Julho de 2002.

Ungar ML. Concentração de mercúrio em exemplares de pescada-do-piauí (Plagioscion squamosissimus) (Heckel, 1840) capturados nos reservatórios das Usinas Hidrelétricas de Barra Bonita e de Rosana, São Paulo, 1994. São Paulo, 
1998. [Tese de Doutorado - Faculdade de Saúde Pública da Universidade de São Paulo].

U.S.EPA. United States Environmental Protection Agency. Integrated Risk Information - IRIS. Methylmercury. 1992.

U.S.EPA. United States Environmental Protection Agency. Mercury study report to Congress. Washington, DC. 1997.

Veiga MM, Fernandes FRC, organizadores. Poconé: Um campo de estudos do impacto ambiental do garimpo. Rio de Janeiro: CETEM/CNPq. 1991. 113p. (Série Tecnologia Ambiental 1).

Vieira LM. Avaliação dos níveis de mercúrio na cadeia trófica como indicador de sua biomagnificação em ambientes aquáticos da região do Pantanal.[Tese de Doutorado - Universidade Federal de São Carlos, 1991].

Walkley A; Black IA. An examination of the degtyareff method for determining soil organic matter and a proposed modification of the cromic acid titration method. Soil Sci 1934; 37: 29-38.

Watras CJ, Bloom NS. Mercury and methylmercury in individual zooplanktonimplications for bioaccumulation. Limnol and Oceanogr 1992; 37(6): 1313-1318.

[WHO]. World Health Organization. Evaluation of mercury, lead, cadmium and food additives amaranth, diethylpyrocarbonate and octyl gallate. Geneva, World Health Organization. p. 1-84. 1972.

[WHO]. World Health Organization. Environmental Health Criteria 1 - Mercury. Geneva, 1976.131p. 
[WHO]. World Health Organization. Environmental Health Criteria 86 Mercury - Environmental Aspects. Genève, 1989. 115p.

[WHO]. World Health Organization. Environmental Health Criteria 101. Methylmercury. Geneva, 1990. 143p.

[WHO]. World Health Organization. Code Guideline Levels for Methylmercury in Fish. [on line] 1991.

Disponível em <URL: http://www.who.int/fsf/Codex/methylmercury.htm> [Janeiro 2003].

WHO. World Health Organization. Regional Office for Europe. Copenhagen. Air Quality Guidelines for Europe. Second Edition. WHO Regional Publications, European Series n ${ }^{\circ}$ 91. 2000.

Wiener JG, Fitzgerald WF, Watras CJ, Rada RG. Partitioning and bioavailability of mercury in an experimentally acidified Wisconsin lake. Environ Toxicol Chem 1990; 9: 909-918.

Yokoo EM. Avaliação da exposição ao metil-mercúrio na população ribeirinha da Baixada Cuiabana, no Pantanal Mato-Grossense - Brasil. Rio de Janeiro; 2001 [Tese de doutorado - Instituto de Medicina Social da Universidade do Estado do Rio de Janeiro]. 